\title{
A CONCRETIZAÇÃO DA PRIVACIDADE DO EMPREGADO NO AMBIENTE DE TRABALHO
}

Dissertação de Mestrado apresentada à Banca Examinadora da Faculdade de Direito da Universidade de São Paulo, como exigência parcial para a obtenção do título de Mestre em Direito, sob orientação do Prof. Dr. Paulo Eduardo Vieira de Oliveira 


\section{RESUMO}

A preocupação com a preservação dos direitos da personalidade do empregado é um movimento característico do direito do trabalho moderno, que concebe o trabalhador como cidadão e titular de todos os direitos fundamentais garantidos constitucionalmente, mesmo que este trabalhador esteja vinculado a um contrato de trabalho. A privacidade, como um direito da personalidade que representa valores morais do ser humano, merece especial atenção no ambiente de trabalho, principalmente em razão da intensificação do uso da tecnologia por parte do empregador para o controle e a fiscalização do empregado, sendo considerada atualmente como elemento essencial para o estabelecimento de um meio ambiente do trabalho sadio. Entretanto, apesar desta preocupação, não há como negar, em razão de o empregado estar inserido na estrutura empresarial, ter a sua atividade subordinada ao empregador e poder praticar atos capazes de afetar direitos fundamentais dos seus colegas de trabalho e de terceiros, que poderão existir situações em que haverá necessidade de limitação da privacidade do trabalhador. Diante desse cenário, a grande discussão que se estabelece é se é possível garantir a concretização do direito à privacidade do trabalhador sem afastar a característica principal da relação de emprego e, principalmente, sem afrontar outros direitos fundamentais de maior ou igual relevância. $\mathrm{O}$ objetivo do presente estudo é imergir nessa discussão a fim de demonstrar ser possível a coexistência de todos os interesses envolvidos e garantir a concretização dos direitos da personalidade do trabalhador observando todos os aspectos que decorrem da relação de emprego. Para tanto, após o estudo do conceito e das características da privacidade e do poder diretivo, a dissertação irá propor o estabelecimento de premissas gerais para garantir a preservação da privacidade do empregado em harmonia com a dinâmica do contrato de trabalho. Essas premissas serão utilizadas para buscar a concretização do direito à privacidade no caso concreto, ou seja, nas diversas situações do dia a dia de uma empresa em que a privacidade do trabalhador é passível de ameaça ou violação. Com o estudo dos casos concretos, a dissertação buscará demonstrar ser possível o estabelecimento de regras para a preservação da privacidade do trabalhador, mesmo diante da ausência de previsão legislativa trabalhista específica sobre a matéria.

\section{Palavras-chave: DIREITOS DA PERSONALIDADE - INTIMIDADE - PRIVACIDADE - PODER DIRETIVO DO EMPREGADOR - CONTROLE.}




\section{ABSTRACT}

The concern with the preservation of employee's personality rights is a characteristic movement of the modern labor law, which conceives the workers as a citizen and holder of all fundamental rights constitutionally assured, even if the worker is bound to an employment agreement. Privacy, as a right of the personality which represents the moral values of the human beings, deserves special attention at the workplace, especially due to the intensified use of technology by the employer to control and supervise the employee, being considered today as an essential element for the establishment of a healthy work environment. However, despite such concern, no one can deny - since the employee is inserted in the corporate structure, having his/her activity subordinated to the employer and being able to perform actions that can affect the fundamental rights of his/her coworkers and third parties - that there may be situations where the privacy of the worker will have to be restrained. In face of this scenario, the main discussion that takes place is if it would be possible to ensure the realization of the worker's right to privacy, without alienating the main characteristics of the employment relationship and, especially, without offense to the other fundamental rights of equal or grater relevance. The purpose of this study is to immerse in this discussion, in order to demonstrate the possibility of coexistence among all the interests involved and to assure the achievement of worker's personality rights, taking in consideration all the aspects arising from the employment relationship. Therefore, after an analysis of the concept and characteristics of privacy and directive power, the thesis will propose the establishment of general premises to ensure the preservation of employee's privacy, in harmony with the dynamics of the employment agreement. Such premises will be used to seek the realization of the right to privacy, in this specific case, that is, in the different situations of the everyday life of a company where the worker's privacy is subject to threats or breaching. By studying real cases, the thesis will seek to demonstrate the possibility of establishing rules to preserve the worker's privacy, eve in face of the absence of specific provisions of the labor law on the matter.

Keywords: PERSONALITY RIGHTS - INTIMACY - PRIVACY - EMPLOYER'S DIRECTIVE POWER - CONTROL. 


\section{SUMÁRIO}

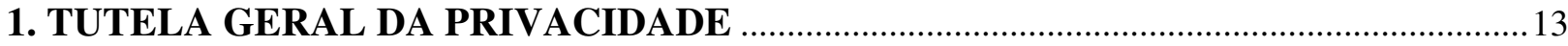

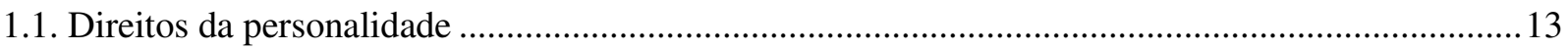

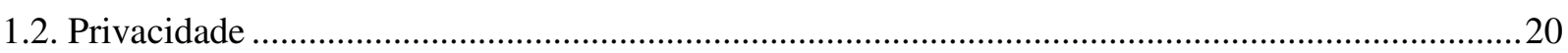

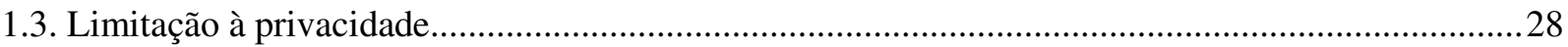

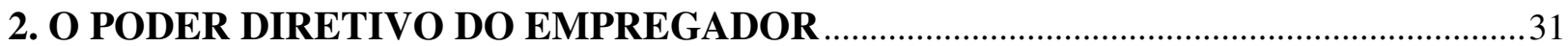

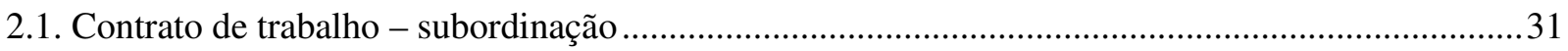

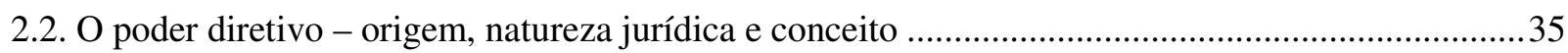

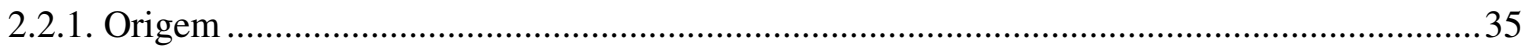

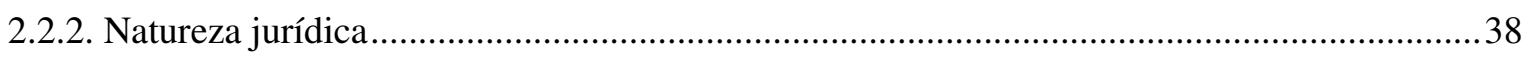

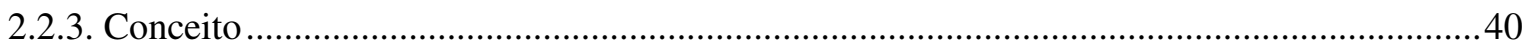

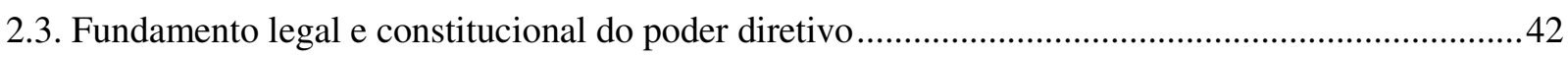

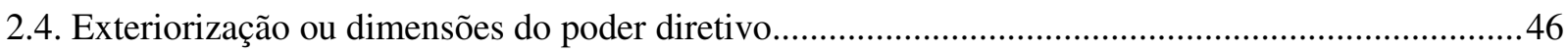

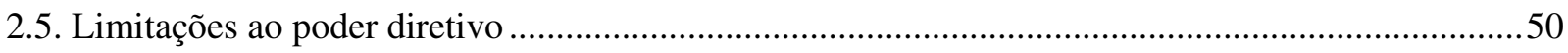

3. O ESTABELECIMENTO DE UM CONCEITO GERAL PARA GARANTIR A PRIVACIDADE DO TRABALHADOR DE ACORDO COM A DINÂMICA DO

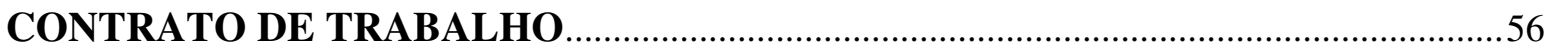

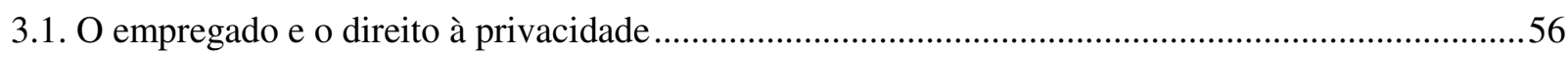

3.2. Direito de propriedade, poder de direção e privacidade do empregado ............................................63

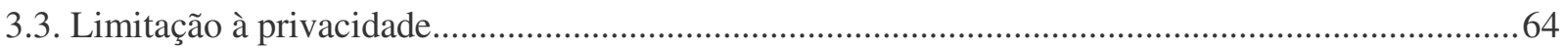

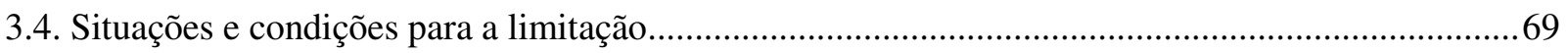

3.4.1. Quando estiverem em jogo outras garantias constitucionais de igual ou maior relevância, especialmente relacionadas a terceiros ou à coletividade ....................................72

3.4.2. Quando for condição para a execução do próprio contrato .................................................. 74

3.4.3. Quando houver forte e concreto indício de má-fé por parte do empregado.............................75

3.4.4. Quando houver indício de má utilização dos instrumentos de trabalho de forma a causar prejuízos a terceiros

3.5. Premissas para que a limitação à privacidade ocorra sem abusos por parte do empregador

3.5.1. Respeito máximo e limitação mínima - manutenção do núcleo essencial da privacidade, como expressão da dignidade da pessoa humana

3.5.2. A limitação deve ser imprescindível, adequada e proporcional, não sendo possível a obtenção do mesmo fim por outros meios. 
3.5.3. Empregado deve ter conhecimento prévio do instrumento utilizado para limitar a privacidade, com a sua respectiva justificativa por parte do empregador, devendo autorizar expressamente a limitação

3.5.4. O instrumento de limitação deve ser negociado com entidades representantes dos trabalhadores (comissão de fábrica, sindicato) e, na ausência destes, deverá contar com a anuência do Ministério Público do Trabalho

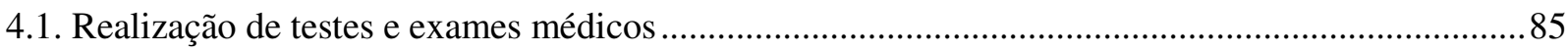

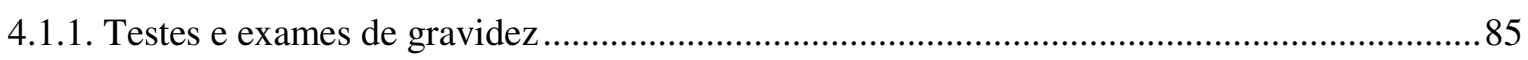

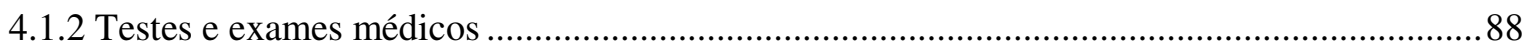

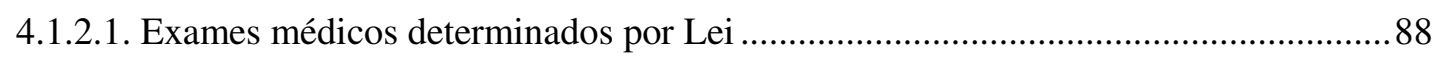

4.1.2.2. Exames de qualquer natureza não determinados por Lei - teste de HIV e

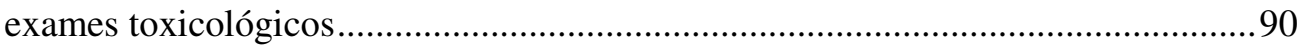

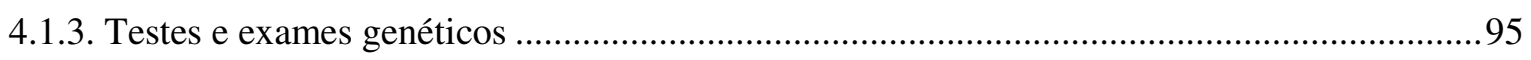

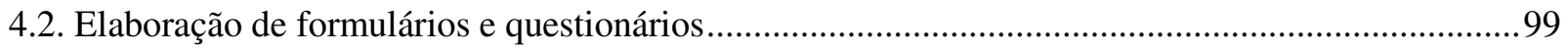

4.3. Direito de omitir informações em entrevista, questionário ou exame ............................................103

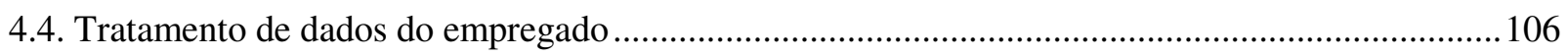

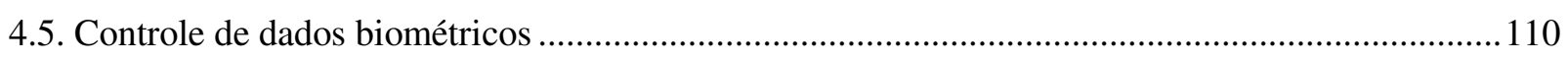

4.6. Sistemas de vigilância presencial e a distância e outras formas de monitoramento.........................112

4.7. Sistemas de gravação de conversas telefônicas ........................................................................... 117

4.8. Contratação de espiões ............................................................................................................. 119

4.9. Monitoramento do correio eletrônico (e-mail) e acesso à rede mundial de computadores

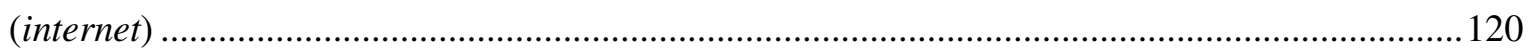

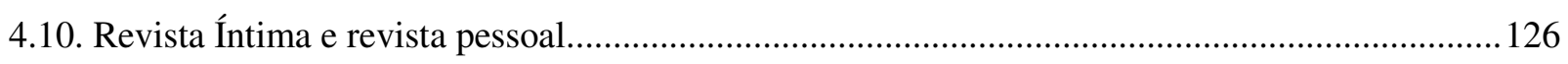

4.11. Controle por meio de polígrafo - detector de mentiras ........................................................... 130

5. INSTRUMENTOS PARA A CONCRETIZAÇÃO DA PRIVACIDADE .........................132

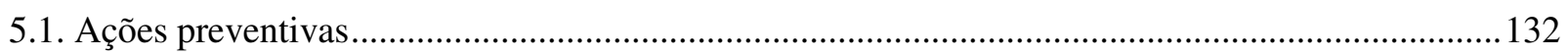

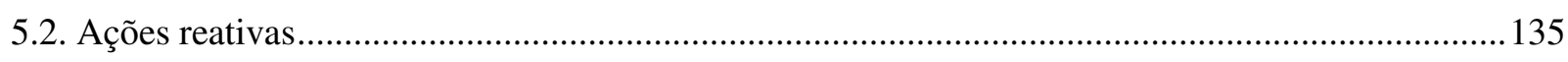

5.2.1. Afronta aos direitos da personalidade - consequências.................................................... 135

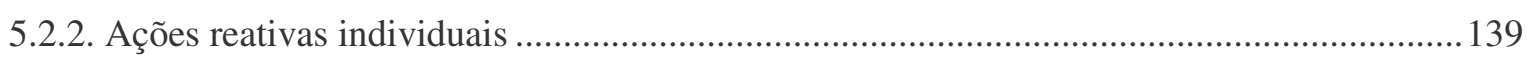

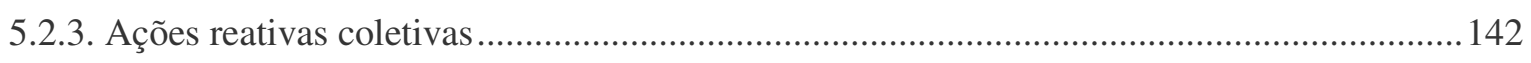

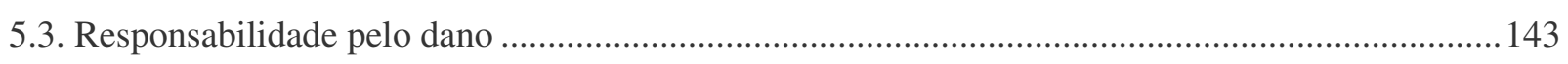

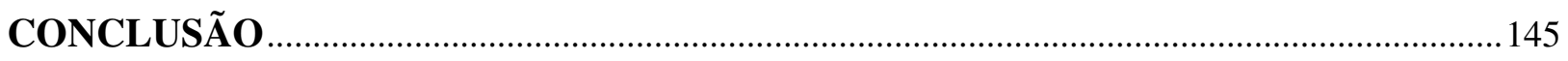

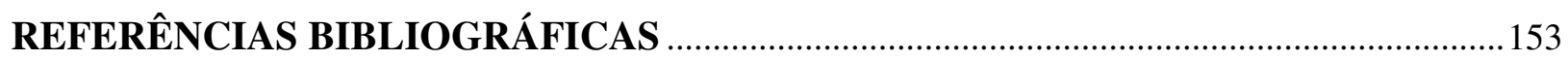




\section{INTRODUÇÃO}

A utilização das novas tecnologias no ambiente de trabalho passou a influenciar diretamente a dinâmica da relação de emprego, modificando os instrumentos de produção, a distribuição do tempo, a divisão do espaço, bem como os mecanismos de controle da produção, acarretando a diminuição da divisão entre o âmbito público e privado, transformando o local de trabalho em ambiente de controle.

$\mathrm{O}$ aumento da produção e da massificação das contratações representadas pelos grandes complexos empresariais distanciou cada vez mais a figura do empregado e do empregador e diminuiu o nível de confiança e presunção de boa-fé que deveria permear a relação de emprego. Esse fator, aliado à necessidade de uma incessante busca por maior produtividade, incentivou a utilização de mecanismos de fiscalização e controle no ambiente de trabalho.

A intensificação do controle do empregado através de aparatos tecnológicos alterou de forma visível e substancial a relação de emprego. Segundo Jorge Luiz Souto Maior, apesar de, sob a ótica da filosofia moderna, o trabalho dignificar o homem, contraditoriamente, a utilização da tecnologia no ambiente de trabalho retira a dignidade humana, impondo limites ao empregado na medida em que o trabalho interfere e avança sobre a sua intimidade e privacidade. ${ }^{1}$

Além dos instrumentos de controle tradicionais, surgiram novos e sofisticados tipos de controle (tais como pesquisas em sites de relacionamento da internet, monitoramento de e-mail, exames genéticos, dentre outros) que visam obter dados do trabalhador alheios à relação de emprego e, sob argumento de traçarem um perfil do empregado, na realidade, acabam invadindo a esfera privada do trabalhador.

Atualmente, o controle não está exclusivamente direcionado aos resultados do trabalho, passando a abranger outros aspectos que o empregador busca valorar, tais como o comportamento do empregado, a forma como se relaciona com os seus colegas e como trabalha em grupo, a forma como executa as tarefas que lhe foram atribuídas, o modo

\footnotetext{
${ }^{1}$ SOUTO MAIOR, Jorge Luiz. Do direito à desconexão do trabalho. Revista do Departamento de Direito do Trabalho e da Seguridade Social, São Paulo, v. 1, n. 1, p. 92, jan./jun. 2006.
} 
como atende o cliente, o entusiasmo que imprime na execução da tarefa, ou, ainda, a eficácia e a rapidez com que executa uma tarefa. ${ }^{2}$

Como se vê, o empregador, amparado na sua posição mais confortável dentro da relação de emprego e na prerrogativa que possui de dirigir e controlar a forma como o serviço é prestado, tem utilizado as mais diversas ferramentas para monitorar o modo como o empregado age dentro e fora do trabalho.

A prática, por ser crônica nas relações de trabalho modernas mereceu expressão específica pela Organização Internacional do Trabalho como "química da intrusão", fazendo referência ao fenômeno da intromissão reiterada na esfera privada do empregado.

Apesar de essa prática patronal ser cada dia mais comum, entendemos ser importante a reflexão sobre a sua pertinência e cabimento, tendo em vista a preocupação com a garantia dos direitos da personalidade do trabalhador, que não deixa a sua condição de cidadão e de detentor de direitos fundamentais a partir do momento em que celebra um contrato de trabalho.

A preocupação com a preservação dos direitos da personalidade na relação de emprego é relativamente recente e traduz a atual tendência do direito do trabalho em buscar o exercício da cidadania na empresa, fenônemo que, segundo Antonio Baylos, se expandiu a partir de 1970 como uma referência ao gozo, no ambiente de trabalho, dos clássicos direitos relacionados à liberdade, tais como liberdade ideológica, de expressão, religiosa, de informação, de privacidade e imagem. ${ }^{3}$

Além de serem essenciais para a noção de empregado-cidadão, os direitos da personalidade possuem papel importante na construção e manutenção de um ambiente de trabalho sadio. Se anteriormente a preocupação em matéria de qualidade de emprego e salubridade do ambiente do trabalho estava voltada unicamente para questões de higiene, segurança e medicina, atualmente, a preocupação é mais ampla, pois abrange todas as questões relacionadas à personalidade do empregado e não apenas a sua saúde. Os riscos para a pessoa do trabalhador não estão limitados às partes do seu corpo, estendem-se a outros domínios da sua pessoa, como a imagem e a dignidade, por exemplo. ${ }^{4}$

\footnotetext{
${ }^{2}$ GUERRA, Amadeu. A privacidade no local de trabalho: as novas tecnologias e o controlo dos trabalhadores através de sistemas automatizados: as alterações do Código do Trabalho. Coimbra: Almedina, 2004. p. 14. ${ }^{3}$ BAYLOS, Antonio. Ciudadanía en el trabajo. Revista do Advogado, São Paulo, ano 30, p. 13, dez. 2010. Relações de Trabalho: Justiça e Equilíbrio. Homenagem a José Granadeiro Guimarães João José Sady. ${ }^{4}$ GOMES, Júlio Manuel Vieira. Direito do trabalho: relações individuais de trabalho. Coimbra: Coimbra Ed., 2007. v. 1, p. 268.
} 
A concepção moderna de meio ambiente do trabalho, conforme destaca Raimundo Simão de Melo, não se limita ao estrito local onde o empregado trabalha, abrangendo, também, os instrumentos fornecidos, o modo de execução das tarefas e a forma como o trabalhador é tratado pelo seu empregador ou por seus colegas de trabalho, razão pela qual o conceito de meio ambiente do trabalho deve levar em consideração a pessoa do trabalhador e tudo que o cerca. ${ }^{5}$

Em razão desse cenário, um dos grandes desafios do direito do trabalho moderno consiste em estabelecer proteções contra potenciais fontes de agressão à privacidade do trabalhador, de forma a concretizar o exercício desse direito da personalidade na relação de emprego.

A preocupação com o tratamento da privacidade na relação de emprego de forma a garantir a concretização desse direito da personalidade no ambiente de trabalho justificou a escolha do tema a ser desenvolvido na presente dissertação.

O presente estudo pretende analisar a privacidade como um direito da personalidade assegurador da dignidade da pessoa humana, sem deixar de se considerar a inserção desse direito na perspectiva da relação de emprego, na qual a atividade do empregado está sujeita ao poder de direção do empregador, como decorrência natural do próprio contrato de trabalho estabelecido entre as partes.

A privacidade será tratada considerando a complexa dinâmica social em que se encontra. Isso significa dizer que o estudo da privacidade no ambiente de trabalho levará em conta a dinâmica da relação de emprego e os aspectos que a envolvem, tais como poder de direção do empregador, deveres e direitos das partes e responsabilidade patronal sobre os atos praticados pelo empregado, sem se afastar da noção de que o trabalhador sempre deve ter preservada a sua dignidade.

O poder de direção, por sua vez, será estudado sob o enfoque da preservação da dignidade da pessoa humana, de forma a não ser utilizado como um instrumento para justificar a violação dos direitos da personalidade do empregado. O estudo pretende demonstrar que, apesar de ter a sua atividade subordinada juridicamente ao empregador, o empregado merece proteção contra as violações de privacidade específicas da relação de emprego, tais como monitoramento eletrônico, verificação de $e$-mail e páginas acessadas na internet, submissão ao detector de mentiras, dentre outras.

\footnotetext{
${ }^{5}$ MELO, Raimundo Simão de. Direito ambiental do trabalho e a saúde do trabalhador. 4. ed. São Paulo: LTr, 2010. p. 31.
} 
A privacidade do empregado e o poder diretivo do empregador, aparentemente antagônicos na relação de emprego, serão analisados sob uma perspectiva integradora, de forma a garantir a concretização efetiva da privacidade do trabalhador dentro de uma lógica empresarial, ou seja, considerando todos os aspectos que envolvem o relacionamento entre empregado, empregador e terceiros.

A dissertação iniciará com a apresentação das bases teóricas e conceituais para o desenvolvimento do tema em estudo, analisando os aspectos que envolvem a privacidade em sentido amplo e o poder diretivo do empregador. O primeiro e o segundo capítulos servirão como base e ponto de partida para a discussão que será travada nos capítulos seguintes, quando esses dois direitos se confrontarão e se integrarão de forma a concretizar a privacidade no ambiente de trabalho.

O primeiro capítulo cuidará do estudo sobre a tutela geral da privacidade, inserindo esse direito na categoria dos direitos da personalidade, com as suas respectivas características. Será estabelecida a diferenciação entre os termos privacidade e intimidade, apresentando-se as diferentes esferas de resguardo do indivíduo e motivo pelo qual elegemos a expressão "privacidade" para fazer referência às esferas íntima e privada da pessoa. ${ }^{6}$ O final do primeiro capítulo tratará dos fatores limitadores ao exercício da privacidade, sem perder de vista a característica de indisponibilidade e irrenunciabilidade desse direito da personalidade.

O segundo capítulo analisará o poder diretivo do empregador, iniciando com o estudo dos elementos que compõem o contrato de trabalho, em especial, a subordinação, que é o fundamento do poder de direção. O poder diretivo será analisado detalhadamente, com a apresentação do seu conceito, características, fundamentos e natureza jurídica. Os desdobramentos do poder diretivo (poder de direção, poder de fiscalização e poder disciplinar) também serão verificados. O direito de propriedade, apesar de não ser considerado como fonte do poder diretivo pela doutrina moderna, merece especial atenção para a finalidade do presente estudo e, portanto, também merecerá análise. O segundo capítulo encerrará com a apresentação dos limitadores ao exercício do poder diretivo do empregador.

\footnotetext{
${ }^{6}$ A presente dissertação concebe a privacidade como o termo que expressa de forma ampla todos os aspectos que envolvem a esfera íntima e privada do indivíduo, razão pela qual foi eleito para ser utilizado ao longo deste estudo, conforme será melhor esclarecido no item 1.2 do capítulo 1.
} 
De posse dos conceitos apresentados no primeiro e segundo capítulos, o trabalho partirá para o estabelecimento de um conceito geral para a concretização da privacidade do empregado mesmo diante do exercício do poder diretivo patronal inerente ao contrato de trabalho.

A dissertação partirá de uma regra geral que entende pela máxima garantia da privacidade do trabalhador no ambiente de trabalho, não aceitando qualquer tipo de limitação deste direito que decorra do puro e simples exercício do direito de propriedade patronal. No entanto, ciente de que nenhum direito é ilimitado e de que existem situações reais na dinâmica da relação laboral que reclamam a adoção de algumas práticas empresariais que podem acarretar a limitação da privacidade do trabalhador, a presente dissertação buscará a coexistência dos direitos envolvidos na dinâmica do trabalho, sem deixar de considerar que o objetivo principal é a proteção do indivíduo. O trabalho apontará as situações nas quais entende ser possível estabelecer a limitação da esfera de resguardo do trabalhador, indicando, também, as condições nas quais isso poderá ocorrer.

O quarto capítulo colocará em prática as premissas estabelecidas no terceiro capítulo e, ao apontar algumas situações da relação de emprego potencialmente ofensivas ao empregado, indicará qual a solução sugerida para a concretização da privacidade do trabalhador. O capítulo analisará a concretização da privacidade do empregado em diversas situações, como: sistemas de vigilância vídeo-eletrônica; aparelhos de gravação de conversas telefônicas; monitoramento de e-mail; revista íntima e revista pessoal; testes e exames médicos; questionários para fins de admissão e realizados na vigência do contrato de trabalho; aplicação do detector de mentiras (polígrafo), dentre outros.

O quinto e último capítulo apontará quais medidas individuais e coletivas poderão ser adotadas para prevenir e/ou ressarcir a violação da privacidade do empregado, especialmente as ações que podem ser adotadas pelo trabalhador, pelas entidades representantes dos empregados, pelo Ministério do Trabalho e Emprego e pelo Ministério Público do Trabalho. Por fim, sem a pretensão de esgotar o tema, o capítulo discorrerá sobre as sanções aplicáveis ao empregador que causar danos à personalidade do seu empregado.

Ao final, a presente dissertação pretende demonstrar que mesmo carecendo a legislação trabalhista de expressa previsão sobre os direitos da personalidade na relação de emprego, é possível a concretização da privacidade do ambiente de trabalho a partir das regras gerais existentes em nossa legislação, até mesmo porque este direito não se 
desassocia da figura do indivíduo, esteja ou não ele na condição de empregado cuja atividade está subordinada ao poder empresarial. 


\section{TUTELA GERAL DA PRIVACIDADE}

\subsection{Direitos da personalidade}

Personalidade é uma característica que traduz as qualidades inerentes ao ser humano, capaz de diferenciar uma pessoa da outra. Os direitos da personalidade são aqueles atinentes à natureza humana, concretizando-a com o objetivo de resguardar a liberdade e a dignidade do indivíduo.

Os direitos da personalidade têm como principal alicerce a garantia da liberdade e da dignidade da pessoa. A vida livre e digna é o pano de fundo necessário para que o homem desenvolva plenamente todas as suas qualidades e características.

A liberdade traduz-se no direito à escolha, à opção, ao livre arbítrio, ao poder de coordenação consciente dos meios necessários para a realização pessoal. ${ }^{7}$ Por representar a faculdade de autodeterminação do indivíduo, é elemento inerente à condição humana digna. Mesmo que exercida dentro dos limites estabelecidos pela sociedade - até mesmo porque esses limites visam, especialmente, garantir o pleno exercício desse direito por todos -, a liberdade é essencial para o desenvolvimento individual do ser humano.

A noção de dignidade da pessoa humana implica em uma obrigação geral de respeito à pessoa, mais precisamente do seu valor intrínseco como indivíduo, traduzido num feixe de direitos e deveres correlativos indispensáveis ao desenvolvimento humano. $\mathrm{O}$ elemento nuclear desta noção está fundamentado, ainda que não exclusivamente, na autonomia e no direito de autodeterminação da pessoa (para a tomada de decisões essenciais a respeito da própria existência), sendo simultaneamente limite e tarefa dos poderes estatatais e da comunidade em geral, de tal sorte a assegurar o papel do ser humano como sujeito de direitos. ${ }^{8}$

Ingo Wolfgang Sarlet entende ser árdua a tarefa de apresentar um conceito fechado de dignidade da pessoa humana, tendo em vista a sua concepção multidimensional, aberta e inclusiva; entretanto, apesar da dificuldade, o autor a define como sendo

\footnotetext{
${ }^{7}$ CHIMENTI, Ricardo Cunha et al. Curso de direito constitucional. 4. ed. São Paulo: Saraiva, 2007. p. 81. ${ }^{8}$ SARLET, Ingo Wolfgang. Dignidade da pessoa humana e direitos fundamentais na Constituição Federal de 1988. 8 ed. rev. ampl. atual. Porto Alegre: Livr. do Advogado, 2010. p. 52-53 e 55-57.
} 
a qualidade intrínseca e distintiva reconhecida em cada ser humano que o faz merecedor do mesmo respeito e consideração por parte do Estado e da comunidade, implicando, neste sentido, um complexo de direitos e deveres fundamentais que assegurem a pessoa tanto contra todo e qualquer ato de cunho degradante e desumano, como venham a lhe garantir as condições existenciais mínimas para uma vida saudável, além de propiciar e promover sua participação ativa e co-responsável nos destinos da própria existência e da vida em comunhão com os demais seres humanos, mediante o devido respeito aos demais seres que integram a rede da vida. ${ }^{9}$

Para Alexandre de Morais trata-se de

um valor espiritual e moral inerente à pessoa, que se manifesta singularmente na autodeterminação consciente e responsável da própria vida e que traz consigo a pretensão ao respeito por parte das demais pessoas, constituindo-se em um mínimo invulnerável que todo estatuto jurídico deve assegurar, de modo que apenas excepcionalmente possam ser feitas limitações ao exercício dos direitos fundamentais, mas sempre sem menosprezar a necessária estima que merecem todas as pessoas enquanto seres humanos. ${ }^{10}$

O legislador constituinte elegeu a dignidade da pessoa humana como um dos fundamentos da República ${ }^{11}$, estabelecendo um elemento de unidade de valor da Constituição que serve como base da construção de todo o ordenamento jurídico. Ingo Wolfgang Sarlet sustenta que com fundamento nesta condição é possível admitir, apesar da omissão do Constituinte, a consagração - ainda que de modo implícito - de um direito ao livre desenvolvimento da personalidade. ${ }^{12}$

Gustavo Tepedino segue a mesma linha e defende que em razão do patamar ao qual foi elevada a dignidade humana na Constituição, há em nosso ordenamento jurídico uma cláusula geral de tutela e promoção da pessoa. ${ }^{13}$

Concordamos com a posição destes dois últimos autores, eis que sendo o direito da personalidade um direito fundamental umbilicalmente vinculado à vida digna, ${ }^{14} \mathrm{a}$

\footnotetext{
${ }^{9}$ SARLET, Ingo Wolfgang. op. cit., p. 70.

${ }^{10}$ MORAES, Alexandre de. Constituição do Brasil interpretada e legislação constitucional. São Paulo: Atlas, 2002. p. 128-129.

11“'Art. $1^{\circ}$. A República Federativa do Brasil, formada pela união indissolúvel dos Estados e Municípios e do Distrito Federal, constitui-se em Estado Democrático de Direito e tem como fundamentos:

(...)

III - a dignidade da pessoa humana; (...)"

${ }^{12}$ SARLET, Ingo Wolfgang. op. cit., p. 99.

${ }^{13}$ TEPEDINO, Gustavo. Temas de direito civil. Rio de Janeiro: Renovar, 1999. p. 48-49.

${ }^{14}$ Apesar de nem todos os direitos fundamentais encontrarem o seu fundamento direto na dignidade da pessoa humana, conforme destaca SARLET in Dignidade da pessoa humana e direitos fundamentais na Constituição Federal de 1988, cit., p. 97.
} 
concepção e interpretação deste direito deve ser feita, portanto, sempre sob a perspectiva de garantir o mínimo necessário para uma existência digna do indivíduo.

Esclarecidos tais aspectos, passamos para a definição do conceito de direito da personalidade.

Rubens Limongi França conceitua direito da personalidade como uma faculdade jurídica cujo objeto abrange os diversos aspectos da pessoa, assim como as suas emanações e prolongamentos. ${ }^{15}$

Os direitos da personalidade, para Carlos Alberto Bittar, são aqueles "reconhecidos à pessoa humana tomada em si mesma e em suas projeções da sociedade, previstos no ordenamento jurídico exatamente para a defesa de valores inatos no homem, como a vida, a higidez física, a intimidade, a honra, a intelectualidade e outros tantos". ${ }^{16}$

Rabindranath Valentino Aleixo Capelo de Sousa faz referência a um direito geral de personalidade e o define como sendo "o direito de cada homem ao respeito e à promoção da globalidade dos elementos, potencialidades e expressões da sua personalidade humana, bem como da unidade psico-físico-sócio ambiental dessa mesma personalidade humana". ${ }^{17}$

Trata-se, portanto, de um direito necessário para o desenvolvimento e a proteção da pessoa em todos os seus aspectos (físico, moral, social, intelectual, etc.) e que não contém em si mesmo uma utilidade imediata de ordem econômica ${ }^{18}$, apesar de a legislação prever indenização pecuniária na hipótese da sua violação.

Os direitos da personalidade são vistos sob dois enfoques pelo direito positivo: público de um lado, como liberdades públicas; e, de outro, privado, como direitos da personalidade, o que lhe imprime feições e disciplinas diversas ${ }^{19}$. Como liberdade pública, a Constituição garante o seu exercício ou proteção perante o Estado, evitando a adoção de medidas por parte do poder público que violam direitos intrínsecos às pessoas dos cidadãos. Sob o aspecto privado, são considerados direitos personalíssimos e

\footnotetext{
${ }^{15}$ FRANÇA, Rubens Limongi. Direitos da personalidade: coordenadas fundamentais. Revista Acadêmica Brasileira de Letras Jurídicas, Rio de Janeiro, v. 7, n. 4, p. 42, 1993.

${ }^{16}$ BITTAR, Carlos Alberto. Os direitos da personalidade. 3. ed. Rio de Janeiro: Forense Universitária, 1999. p. 1.

${ }^{17}$ SOUSA, Radindranath Valentino Aleixo Capelo de. O direito geral de personalidade. Coimbra: Coimbra Ed., 1995. p. 26.

${ }^{18}$ DE CUPIS, Adriano. Os direitos da personalidade. Tradução de Adriano Vera Jardim e Antônio Miguel Caeiro. Lisboa: Livraria Morais, 1961. p. 29.

${ }^{19}$ BITTAR, Carlos Alberto. op. cit., p. 5.
} 
fundamentais, sendo que a Constituição garante a sua preservação no relacionamento entre particulares, protegendo o indivíduo contra ameaças e agressões de terceiros particulares, a exemplo do artigo $5^{\circ}$, incisos X, XI e XII. Para a finalidade da presente dissertação, estudaremos os direitos da personalidade sob o segundo enfoque, qual seja, como um direito fundamental.

O legislador constituinte elevou os direitos da personalidade ao status máximo de proteção, a ponto de a proteção aos bens da personalidade ter sido incluída como cláusula pétrea da Constituição de 1988, conforme dispõe o seu artigo 60, parágrafo $4^{\circ}$, inciso IV.

No âmbito infraconstitucional, o artigo 11 do Código Civil de 2002, ao contrário do Código de 1916, dispõe expressamente sobre os direitos da personalidade, qualificando-os como intransmissíveis e irrenunciáveis, impedindo a limitação voluntária do seu exercício, salvo os casos previstos em lei. ${ }^{20}$ De igual forma, o caput do artigo 12 do mesmo diploma legal determina que “[...] pode-se exigir que cesse a ameaça, ou a lesão, a direito da personalidade, e reclamar perdas e danos, sem prejuízo de outras sanções previstas em lei $[\ldots] "$.

No entanto, a moderna concepção sobre os direitos da personalidade não está limitada à previsão legal contida na Constituição e, principalmente, na legislação infraconstitucional, notadamente os artigos 11 a 21 do Código Civil que disciplinam a matéria de forma expressa. Washington de Barros Monteiro e Caio Mario da Silva Pereira seguem essa linha e sustentam que os direitos da personalidade elencados no inciso $\mathrm{X}$ do artigo $5^{\circ}$ da Constituição Federal são o mínimo necessário para preservação do indivíduo, nada impedindo que outros sejam arrolados em lei. ${ }^{21}$

Daniel Sarmento também defende que a tipificação pontual dos artigos 11 a 21 do Código Civil não esgota a tutela dos direitos da personalidade, uma vez que esta se encontra, por imperativo constitucional, no centro do direito privado, projetando-se por todos os seus campos. ${ }^{22}$

Concordamos com os autores citados, entendendo ser possível utilizar a "cláusula geral de tutela e promoção da pessoa humana" destacada por Gustavo Tepedino ${ }^{23}$ para

\footnotetext{
${ }^{20}$ Artigo 11 CC 2002 "Com exceção dos casos previstos em lei, os direitos da personalidade são intransmissíveis e irrenunciáveis, não podendo o seu exercício sofrer limitação voluntária”.

${ }^{21}$ MONTEIRO, Washington de Barros. Curso de direito civil. 39. ed. São Paulo: Saraiva, 2003. v. 1, p. 97 e PEREIRA, Caio Mario da Silva. Instituições de direito civil. 20. ed. Rio de Janeiro: Forense, 2004. v. 1, p. 241.

${ }^{22}$ SARMENTO, Daniel. Direitos fundamentais e relações privadas. Rio de Janeiro: Lumen Juris, 2004. p. 122.

${ }^{23}$ TEPEDINO, Gustavo. op. cit., p. 48-49.
} 
garantir o respeito aos direitos da personalidade para situações não previstas em lei. A teoria geral de personalidade atua com preceitos abertos, de forma a permitir a evolução e a modificação de seus conteúdos em função das alterações e necessidades da sociedade. Sem se confundir com os direitos da personalidade em espécie, a teoria geral da personalidade lhe serve de fundamento como um "direito fonte". ${ }^{24}$

O reconhecimento de uma tutela geral de privacidade representa a evolução das relações sociais, econômicas e jurídicas, especialmente no que diz respeito ao reconhecimento da personalidade e da capacidade jurídica de todos os cidadãos. ${ }^{25}$

As características dos direitos da personalidade são enumeradas, na sua grande maioria, pela doutrina civilista, que é unânime ao concebê-los como sendo intransmissíveis; inalienáveis, impossíveis de serem adquiridos por outrem; irrenunciáveis, salvo os casos previstos em lei; inextinguíveis, exceto na morte da pessoa; não sujeitos a execução forçada; imprescindíveis e ligados ao indivíduo de forma permanente. ${ }^{26}$

Para Carlos Alberto Bittar, os direitos da personalidade impõem limites à própria ação do titular, que não pode eliminá-los por ato de vontade. Entretanto, entende que o titular pode dispor dos direitos sob certos aspectos. ${ }^{27}$

Apesar de apontar a irrenunciabilidade como uma das características dos direitos da personalidade, Adriano De Cupis reconhece ser possível o titular consentir no seu exercício. $^{28}$

Ao analisar as características dos direitos da personalidade apontados por Adriano De Cupis, em especial quanto ao consentimento, Sandra Lia Simón pondera que a concordância não representa a renúncia do direito, pois se o titular admite a lesão de um direito da personalidade, a pessoa que receber tal autorização poderá limitar o direito de forma legítima, sem que isso represente a sua extinção. Para a autora,

\footnotetext{
${ }^{24}$ CARNAVAN, Fernando Leone. Tutela dos direitos da personalidade no direito do trabalho. 2002. Dissertação (Mestrado em Direito) - Faculdade de Direito, Universidade de São Paulo, São Paulo, 2002. p. 19.

${ }^{25}$ SOUSA, Radindranath Valentino Aleixo Capelo de. op. cit., p. 27.

${ }^{26}$ Nesse sentido: MIRANDA, Francisco Cavalcanti Pontes de. Tratado de direito privado: parte especial. Rio de Janeiro: Borsoi, 1955. v. 8, p. 5-6; RODRIGUES, Silvio. Direito civil: parte geral. 23. ed., atual. São Paulo: Saraiva, 1993. v. 1, p. 61.; MONTEIRO, Washington de Barros. op. cit., v. 1, p. 97 e PEREIRA, Caio Mario da Silva. op. cit., v. 1, p. 97; BITTAR, Carlos Alberto. op. cit., p. 5.

${ }^{27}$ BITTAR, Carlos Alberto. op. cit., p. 5.

${ }^{28}$ DE CUPIS, Adriano. Os direitos da personalidade. Tradução de Adriano Vera Jardim e Antônio Miguel Caeiro. Lisboa: Livraria Morais, 1961. p. 30.
} 
o fato de se consentir na lesão equivale à faculdade de estipular o destino de um direito subjetivo e, nesse sentido, o ato de disposição não atingirá a essência do direito. Para identificarem-se os direitos que podem ser 'violados por consentimento do titular', De Cupis traça duas regras básicas: a primeira só se aplica no campo penal, de maneira que toda vez que houver interesse público em jogo o titular não poderá autorizar a lesão (p. ex., na tutela do direito à vida); a segunda diz respeito ao conjunto do ordenamento jurídico, de modo que a disponibilidade dos direitos da personalidade só poderá ser admitida se estiver de acordo com o caráter geral da legislação, observando-se a 'ordem pública', e os 'bons costumes'. A característica da indisponibilidade, portanto, deve ser considerada por

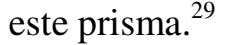

Rui Stoco, discorrendo sobre as exceções à regra da instransmissibilidade e irrenunciabilidade dos direitos de personalidade, afirma que não existe regra sem exceção, sustentando que o nosso ordenamento jurídico, assim como o dos países mais evoluídos, repugna qualquer direito absoluto, sendo que atualmente vigora o princípio de relatividade dos direitos. Para o autor, os direitos personalíssimos não são absolutamente indisponíveis, tendo em vista que alguns desses direitos podem circular por via contratual, preferencialmente por convenção escrita e podem ser objeto de transações por vontade própria do titular. Como exemplo, cita o direito à imagem (cessão de direitos autoriais), ao nome e à voz. ${ }^{30}$

A possibilidade de consentimento para a limitação dos direitos da personalidade nos parece aceitável, pois consentir não significa tornar disponível ou renunciar, desde que mantido o núcleo essencial do direito. Neste sentido, acolhemos os argumentos de Sandra Lia Simón de que é facultado ao detentor do direito da personalidade decidir sobre o destino de um direito objetivo, sendo que o ato de disposição não será capaz de eliminá-lo completamente ou, tampouco, atingir a essência do direito.

No entanto, a questão do consentimento dos direitos da personalidade, especialmente na relação de emprego, merece análise cuidadosa, visto que a condição de hipossuficência do empregado põe em dúvida qualquer manifestação de autonomia de vontade em qualquer fase do contrato de trabalho. Este tema será analisado de forma detalhada no capítulo 3 do presente trabalho, razão pela qual deixaremos essa discussão

\footnotetext{
${ }^{29}$ SIMÓN, Sandra Lia. A proteção constitucional da intimidade e da vida privada do empregado. São Paulo: LTr, 2000. p. 64-65.

${ }^{30}$ STOCO, Rui. Tratado de responsabilidade civil. 6. ed. rev. atual. e ampl. São Paulo: Ed. Revista dos Tribunais, 2004. p. 1615-1616.
} 
parcialmente de lado para antes verificar a classificação dos direitos da personalidade pela doutrina, que o divide em diversas categorias.

Adriano De Cupis ${ }^{31}$ classifica os direitos da personalidade da seguinte forma: direito à vida e à integridade física; direito sobre as partes destacadas do corpo e direito sobre o cadáver; direito à liberdade; direito ao resguardo (direito à honra, ao resguardo e ao segredo); direito à identidade pessoal (direito ao nome, ao título e ao sinal pessoal); e direito moral de autor.

Rubens Limongi França apresenta a seguinte classificação: direito à integridade física (direito à vida e aos alimentos; direito sobre o próprio corpo, vivo; direito ao próprio corpo, morto; direito sobre o corpo alheio, vivo; direito sobre o corpo alheio, morto; direito sobre as partes separadas do corpo, vivo; direito sobre as partes separadas do corpo, morto); direito à integridade intelectual (direito à liberdade de pensamento; direito pessoal de autor científico; direito pessoal de autor artístico; direito pessoal de inventor); e direito à integridade moral (direito à liberdade civil, política e religiosa; direito à honra; direito à honorificência; direito ao recato; direito ao segredo pessoal, doméstico e profissional; direito à imagem; direito à identidade pessoal, familiar e social). ${ }^{32}$

Paulo Eduardo Vieira de Oliveira, ao enumerar os direitos da personalidade de acordo com os critérios estabelecidos pela doutrina, acrescenta um quarto grupo à classificação de Limongi França. Trata-se do direito à integridade social. Para o autor, o referido direito representa $\mathrm{o}$

\begin{abstract}
ser essencialmente político, essencialmente social, a pessoa humana tem direito ao convívio familiar, ao convívio com 'grupos intermediários' existentes entre o indivíduo e o Estado, grupos a que se associa pelas mais diversas razões (recreação, defesa de interesses corportativos, por convicção religiosa, por opção político-partidária, etc.), direito do exercício da cidadania (esta tomada no sentido estrito [status ligado ao regime político] e no sentido lato: direito de usufruir de todos os bens de que a sociedade dispõe ou deve dispor para todos e não só para eupátridas, tais como: educação escolar nos diversos níveis, seguridade social [saúde pública, da previdência ou da assistência social] ${ }^{33}$.
\end{abstract}

Para a finalidade da presente dissertação, nos interessa o estudo dos direitos à intimidade e à privacidade, que estão relacionados ao direito ao resguardo, na classificação de Adriano De Cupis, ou à integridade moral, na classificação de Limongi França. Para

\footnotetext{
${ }^{31}$ DE CUPIS, Adriano. op. cit., p. 38.

${ }^{32}$ FRANÇA, Rubens Limongi. op. cit., p. 43.

${ }^{33}$ OLIVEIRA, Paulo Eduardo Vieira. O dano pessoal no direito do trabalho. São Paulo: LTr, 2002. p. 26-27.
} 
fins de classificação, adotaremos os critérios apresentados por Limongi França, razão pela qual concebemos o direito à privacidade e à intimidade como direitos da personalidade que integram valores morais do ser humano.

\subsection{Privacidade}

Antes de iniciarmos o estudo do conceito e das características deste direito da personalidade relacionado à integridade moral do indivíduo, faz-se necessário esclarecer o motivo pelo qual o presente trabalho elegeu o termo "privacidade" em detrimento de outras expressões utilizadas pela doutrina e pela jurisprudência.

Não há harmonia na doutrina e na jurisprudência, tanto estrangeira quanto nacional, sobre a correta e mais adequada expressão a ser utilizada para se referir a este direito da personalidade que visa preservar a integridade moral da pessoa.

De fato, a doutrina e jurisprudência estrangeira não possuem um consenso sobre o termo a ser utilizado. Citamos, como exemplo, a referência à privacy norte-americana, ao droit au secret de la vie privée ou simplesmente la protection de la vie privée na França; ao diritto alla risevatezza (ou a segretezza) ou mesmo a privacy, utilizados na Itália; à reserva da intimidade da vida privada utilizada em Portugal; ao derecho a la intimidad utilizado na Espanha; à noção da die privatsphäre, que divide a autonomia individual e a vida social, presente na doutrina da Alemanha. Todas essas expressões são algumas das designações utilizadas para se referir ao complexo de interesses que remetem ao termo privacidade ou intimidade.

A doutrina e a jurisprudência nacional, antes da Constituição da República de 1988, possivelmente influenciados pela tradução de expressões estrangeiras, utilizavam as expressões "intimidade", "vida privada" e "privacidade" como sinônimos. ${ }^{34}$ A redação do inciso $\mathrm{X}$ do artigo $5^{\circ}$ da Constituição, que faz referência à proteção da intimidade e da vida privada, em um primeiro momento, levou à ideia de que a doutrina e a jurisprudência brasileiras utilizariam esses dois termos de forma distinta. No entanto, a previsão do Código Civil de 2002 não auxiliou na solução da discussão ao excluir o termo "intimidade" da sua previsão, fazendo referência apenas à "vida privada".

\footnotetext{
${ }^{34}$ LEWICKI, Bruno. A privacidade da pessoa humana no ambiente de trabalho. Rio de Janeiro: Renovar, 2003. p. 29.
} 
Assim, mesmo após a Constituição de 1988, a doutrina nacional não firmou um consenso no sentido do termo a ser utilizado para se referir a este direito da personalidade que representa o valor moral do ser humano. A profusão de expressões que a doutrina brasileira se utiliza para representar a privacidade, propriamente ou não, é considerável. Além da expressão "privacidade" propriamente dita, podemos citar, por exemplo: "vida privada", "intimidade", "segredo", "sigilo", "recato", "reserva", "intimidade da vida privada", e outros menos utilizados, como "privatividade" e "privaticidade". 35

Alguns doutrinadores, como Alice Monteiro de Barros, por exemplo, utilizam as expressões "privacidade" e "intimidade" como sinônimos, elegendo o termo "intimidade", sob o ponto de vista jurídico, para fazer referência às duas esferas de resguardo do indivíduo. ${ }^{36}$ Contudo, a maior parte da doutrina nacional tem se inclinado a diferenciar os conceitos de vida privada e intimidade, certamente influenciada pelo fato de o constituinte nacional ter utilizado os dois termos na previsão do inciso X do artigo $5^{\circ}$ da Carta Magna.

José Afonso da Silva, ao analisar a redação do inciso X do artigo $5^{\circ}$ da Constituição Federal, esclarece que a intenção do constituinte foi a de diferenciar vida privada da intimidade. No entendimento do autor, a intimidade integra a esfera íntima do indivíduo, os seus pensamentos, desejos e convicções, enquanto a vida privada representa o direito da pessoa de ser e viver a vida própria, relacionando-se com quem bem entender. Observa que a Constituição se refere à vida privada, como o conjunto de modo de ser e de viver, como direito de o indivíduo viver a sua própria vida. Por sua vez, a intimidade é mais restrita e abrange a inviolabilidade do domicílio, o sigilo da correspondência e o segredo profissional. $^{37}$

Grande parte dos doutrinadores nacionais relaciona a intimidade a questões íntimas da pessoa, que o indivíduo mantém no seu âmbito pessoal, resguardando também de pessoas de seu convívio mais próximo. A privacidade, por sua vez, envolve questões que a pessoa pretende resguardar do grande público. Apesar da diferenciação apresentada, os

\footnotetext{
${ }^{35}$ DONEDA, Danilo. Privacidade, vida privada e intimidade no ordenamento jurídico brasileiro: da emergência de uma revisão conceitual e da tutela de dados pessoais. Ambito Jurídico. Disponível em: <http://www.ambito-juridico.com.br/site/index.php?n_link=revista_artigos_leitura\&artigo_id=2460>. Acesso em: 28 set. 2010.

${ }^{36}$ BARROS, Alice Monteiro de. Proteção à intimidade do empregado. São Paulo: LTr, 1997. p. 27-29.

${ }^{37}$ SILVA, José Afonso da. Curso de direito constitucional positivo. 9 ed. São Paulo: Malheiros Ed., 1994. p. 188-189.
} 
doutrinadores entendem que a intimidade, por ser mais restrita, é envolvida pela privacidade, que possui maior amplitude. ${ }^{38}$

As diferentes amplitudes de resguardo do indivíduo constantemente mencionadas pela doutrina baseiam-se na teoria de Hubmann, que divide as esferas da seguinte forma: (i) Esfera íntima ou secreta, também conhecida como da intimidade ou do segredo (Intimsphäre) - compreende todos os fatos que devem, objetivamente, ser inacessíveis a terceiros e absolutamente protegidos da curiosidade alheia. Representa a esfera mais restrita e inclui as informações que dizem respeito aos aspectos da vida familiar, aos comportamentos sexuais, às práticas de convicções religiosas e ao estado de saúde; (ii) Esfera privada (Privatsphäre) - compreende todos os fatos cujo conhecimento o titular tem, subjetivamente, o interesse em guardar para si. São fatos da sua vida profissional, seu domicílio e hábitos de vida; e (iii) Esfera pública ou da vida pública (Öffentlichkeit) compreende todos os fatos e situações do conhecimento público. ${ }^{39}$

Se fosse possível apontar uma escala de amplitude do resguardo do indivíduo, partindo do mais abrangente (onde o público confunde-se com o privado) para o mais restrito, a vida privada estaria em primeiro lugar, como aspecto mais amplo que a intimidade. E, por segundo, como célula restrita e limitada, teríamos a intimidade. Quanto mais restrita a esfera de resguardo maior a proteção a ser conferida pela legislação. ${ }^{40}$

Danilo Doneda critica a doutrina de Hubmann, sustentando que atualmente esta é concebida pela própria doutrina alemã como a teoria da "pessoa como uma cebola passiva", tendo perdido a sua centralidade após uma célebre sentença proferida em 1983 pelo Tribunal Constitucional Alemão. ${ }^{41}$

A teoria também sofre críticas de alguns autores portugueses, dentre os quais está Teresa Alexandra Coelho Moreira que entende que a dignidade de uma pessoa existe independentemente da esfera protegida, destacando que nem a doutrina ou a jurisprudência conseguiram realmente concretizar o conteúdo exato das três esferas. Para a autora, atualmente, a proteção de vida privada constitui um caso que está incluído no direito geral

\footnotetext{
${ }^{38}$ Nesse sentido: MORAES, Alexandre de. Direito constitucional. 16 ed. São Paulo: Atlas, 2004. p. 82; ARAÚJO; Luiz Alberto David; NUNES JÚNIOR, Vidal Serrano apud; SIMÓN, Sandra Lia. op. cit., p. 101.

${ }^{39}$ LEITÃO, Luís Menezes, A protecção dos dados pessoais no Código do Trabalho: a Reforma do Código do Trabalho. Coimbra, 2004. p. 124.

${ }^{40}$ Id., loc. cit.

${ }^{41}$ DONEDA, Danilo. op. cit.
} 
de personalidade. ${ }^{42}$ Outra autora é Maria Regina Redinha, que sustenta não ser possível determinar objetivamente a amplitude das esferas da privacidade, eis que esta varia de acordo com a posição particular do indivíduo, nomeadamente a sua notoriedade, exposição pública, atividade profissional, funções desempenhadas e até mesmo a forma como esta pessoa estabelece a sua privacidade, uma vez que a fronteira entre a esfera pública e privada é, em larga medida, definida pelo indivíduo. ${ }^{43}$

Independentemente da diferenciação e da amplitude entre os conceitos de privacidade e intimidade, entendemos que a característica comum a ambos se dá no respeito que tanto o Estado como os particulares devem manter em face da pessoa e do nível de liberdade que o indivíduo estabeleceu em relação a terceiros e a si mesmo.

Após as considerações acima, esclarecemos que o presente trabalho optou por utilizar o termo "privacidade" em sentido genérico, fazendo referência ao conjunto de aspectos íntimos e privados da personalidade do indivíduo, por entender que esta expressão abrange e engloba tanto a intimidade como a vida privada.

O termo privacidade também é utilizado por José Afonso da Silva em "sentido genérico e amplo, de modo a abarcar todas essas manifestações da esfera íntima, privada e da personalidade, que o texto constitucional em exame consagrou". ${ }^{4}$

Danilo Doneda referenda a nossa opção, pois entende que utilizar o termo privacidade parece a alternativa mais razoável e eficaz, sendo essa expressão específica o suficiente para distingui-la de outros termos com os quais eventualmente deve medir-se, como a imagem, a honra ou a identidade pessoal, e, também, por unificar os valores expressos pelos termos intimidade e vida privada. ${ }^{45}$

A privacidade é concebida como um aspecto fundamental da realização e formação da pessoa, bem como do desenvolvimento da sua personalidade. A definição do que deverá ser exposto ou não sobre alguém, do que se quer tornar público ou o que se quer esconder, ou a quem se deseja revelar algo, mais do que meramente uma preferência ou capricho, define propriamente quem é o indivíduo e as fronteiras e grau de interação e comunicação

\footnotetext{
${ }^{42}$ MOREIRA, Teresa Alexandra Coelho. Da esfera privada do trabalhador e o controlo do empregador. Coimbra: Coimbra Ed., 2004. p. 87.

${ }^{43}$ REDINHA, Maria Regina. Direitos de personalidade, p. 2. Disponível em: <www.direito.up.pt/cije_web/backoffice/uploads/publicacoes/direitos_personalidade_anot.pdf>. Acesso em: 10 mar. 2009.

${ }^{44}$ SILVA, José Afonso da. op. cit., p. 188.

${ }^{45}$ DONEDA, Danilo. op. cit.
} 
que pretende estabelecer os seus conhecidos, seus familiares e todos os demais indivíduos da sociedade. ${ }^{46}$

A primeira grande formulação jurídica sobre o direito à privacidade ocorreu no artigo elaborado pelos norte-americanos Samuel Warren e Louis Brandeis com o título The Right to Privacy (Do direito à privacidade), publicado no n. 5, volume IV da edição de 15 de dezembro de 1890 da revista Harvard Law Review. O estudo examinou a problemática da privacidade em contraponto com o abuso de liberdade de imprensa. É considerado como o marco inicial da discussão teórica, em termos jurídicos, do direito à privacidade. Teve como objetivo desestimular a intromissão da imprensa na vida e honra das pessoas. ${ }^{47}$

O estudo americano desencadeou uma alteração no conceito de privacidade, que deixou de ser considerado um bem do indivíduo ${ }^{48}$ e passou a ser encarado atributo da personalidade da pessoa, como bem ou direito da personalidade.

$\mathrm{Na}$ Europa, a necessidade de tutelar a intimidade fez-se sentir anos após. A Alemanha enfrentou o problema através do projeto de reforma do Código Penal Enterwurf, 1962, dedicando todo o $7^{\circ}$ título às lesões provocadas na esfera privada e no segredo. Na Itália, a discussão surgiu após a última grande guerra, provocada pela tentativa de publicação seriada dos amores de Benito Mussolini e Claretta Pitacci. A atenção gerada pelo assunto fez com que surgissem congressos para discutir o tema. ${ }^{49}$

No entanto, antes mesmo do estudo dos juristas norte-americanos é possível constatar, na Declaração dos Direitos do Homem e do Cidadão (1789) ${ }^{50}$, a preocupação

\footnotetext{
${ }^{46}$ DONEDA, Danilo. op. cit.

${ }^{47}$ PENDAS, Benigno. Introdução. In: THE RIGHT to privacy para o espanhol sob o título El derecho a la intimidad. Madrid: Civitas, 1995. p. 9-17.

48،Cuja titularidade correspondia ao pleno domínio do sujeito como se fosse um move ou imóvel” (VELÁZQUEZ BAUTISTA apud BARROS, Alice Monteiro de. Proteção à intimidade do empregado, cit., p. 21).

${ }^{49}$ COSTA JÚNIOR, Paulo José. $O$ direito de estar só: tutela penal da intimidade. São Paulo: Ed. Revista dos Tribunais, 1970. p. 11-12.

${ }^{50}$ Artigo $1^{\circ}$ Os homens nascem livres e iguais em direitos. As distinções sociais só podem fundamentar-se na utilidade comum;

Artigo $2^{\circ}$ A finalidade de toda associação política é a conservação dos direitos naturais e imprescritíveis do homem. Esses direitos são a liberdade, a prosperidade, a segurança e a resistência à opressão.

Artigo $4^{\circ}$ A liberdade consiste em poder fazer tudo que não prejudique o próximo. Assim, o exercício dos direitos naturais de cada homem não tem por limites senão aqueles que asseguram aos outros membros da sociedade o gozo dos mesmos direitos. Estes limites apenas podem ser determinados pela lei.

Artigo 10 Ninguém poderá ser molestado por suas opiniões, incluindo opiniões religiosas, desde que sua manifestação não perturbe a ordem pública estabelecida pela lei.

Artigo 11 A livre comunicação das idéias e das opiniões é um dos mais preciosos direitos do homem. Todo o cidadão pode, portanto, falar, escrever, imprimir livremente, respondendo, todavia, pelos abusos desta liberdade nos termos previstos na lei. (fonte: UNIVERSIDADE DE SÃO PAULO. Biblioteca Virtual de Direitos Humanos. Disponível em: <www.direitoshumanos.usp.br>).
} 
com a proteção da privacidade. Essa preocupação seguiu-se, no âmbito internacional, após

a Segunda Guerra Mundial, em várias declarações internacionais de direitos, como na Declaração Universal dos Direitos Humanos $(1948)^{51}$, na Convenção Europeia dos Direitos Humanos (1950) ${ }^{52}$ e na Convenção Americana dos Direitos Humanos - Pacto de San José de Costa Rica (1969) ${ }^{53}$ e, mais recentemente, na Carta dos Direitos Fundamentais da União Europeia $(2000)^{54}$.

O despertar do direito para a discussão sobre a privacidade ocorreu justamente em um período em que houve uma mudança na percepção da pessoa humana pelo ordenamento jurídico, do qual ela passou a ocupar papel central e ao qual se seguiu a normatização de vários aspectos do cotidiano. ${ }^{55}$

No âmbito legislativo brasileiro, conforme já destacado, somente com o advento da Constituição Federal de 1988 houve uma normatização ampla e efetiva de proteção à privacidade, garantindo, de forma expressa, as clássicas manifestações do direito à

\footnotetext{
${ }^{51}$ Artigo 12 Ninguém será sujeito a interferências na sua vida privada, na sua família, no seu lar ou na sua correspondência, nem a ataques à sua honra e reputação. Toda a pessoa tem direito à proteção da lei contra tais interferências ou ataques. (fonte: UNIVERSIDADE DE SÃO PAULO. Biblioteca Virtual de Direitos Humanos. Disponível em: <www.direitoshumanos.usp.br>).

${ }^{52}$ Artigo $8^{\circ}$,

1. Qualquer pessoa tem direito ao respeito da sua vida privada e familiar, do seu domicílio e da sua correspondência.

2. Não pode haver ingerência da autoridade pública no exercício deste direito senão quando esta ingerência estiver prevista na lei e constituir uma providência que, numa sociedade democrática, seja necessária para a segurança nacional, para a segurança pública, para o bem-estar econômico do país, a defesa da ordem e a prevenção das infrações penais, a proteção da saúde ou da moral, ou a proteção dos direitos e das liberdades de terceiros. (fonte: CONSELHO DA EUROPA. Convenção para a Protecção dos Direitos do Homem e das Liberdades Fundamentais (Modificada nos termos das disposições do Protocolo n¹1). Gabinete de Documentação e Direito Comnparado. Disponível em: <www.gddc.pt/direitos-humanos/textosinternacionais-dh/tidhregionais/conv-tratados-04-11-950-ets-5.html>. Acesso em: 02 dez. 2010).

${ }^{53}$ Artigo 11 Proteção da honra e da dignidade

$\S 1$. Toda pessoa tem direito ao respeito da sua honra e ao reconhecimento de sua dignidade.

$\S 2$. Ninguém pode ser objeto de ingerências arbitrárias ou abusivas em sua vida privada, em sua família, em seu domicílio ou em sua correspondência, nem de ofensas ilegais à sua honra ou reputação.

§3. Toda pessoa tem direito à proteção da lei contra tais ingerências ou tais ofensas. (fonte: UNIVERSIDADE DE SÃO PAULO. Biblioteca Virtual de Direitos Humanos. Disponível em: $<$ www.direitoshumanos.usp.br>).

${ }^{54}$ Art. $7^{\circ}$ - Respeito pela vida privada e familiar

Todas as pessoas têm direito ao respeito pela sua vida privada e familiar, pelo seu domicílio e pelas suas comunicações.

Artigo $8^{\circ}$ - Protecção de dados pessoais

1. Todas as pessoas têm direito à protecção dos dados de caráter pessoal que lhes digam respeito.

2. Esses dados devem ser objeto de um tratamento leal, para fins específicos e com o consentimento da pessoa interessada ou com outro fundamento legítimo previsto por lei. Todas as pessoas têm o direito de aceder aos dados coligidos que lhes digam respeito e de obter a respectiva retificação.

3. O cumprimento destas regras fica sujeito a fiscalização por parte de uma autoridade independente. (fonte: EUROPEAN PARLIAMENT. Carta dos Direitos Fundamentais da União Européia. Jornal Oficial das Comunidades Européias, C364/1, 18.12.2000. Disponível em: $<$ http://www.europarl.europa.eu/charter/pdf/text_pt.pdf>. Acesso em: 18 nov. 2010).

${ }^{55}$ DONEDA, Danilo. Da privacidade à proteção de dados pessoais. Rio de Janeiro: Renovar, 2006. p. 8.
} 
intimidade e à vida privada. A norma constitucional buscou garantir três modalidades de resguardo do indivíduo, a saber: a individual, a da moradia e das telecomunicações. ${ }^{56}$

A importância do tratamento da privacidade na Constituição Federal reflete a consagração da dignidade da pessoa humana como fundamento da República Federativa do Brasil.

A configuração da Constituição Federal deixa nítida a grande preocupação do constituinte em assegurar, em todas as suas formas, o direito à intimidade e à vida privada. Primeiro, sob a forma genérica, na redação do caput do artigo $5^{\circ}$. Por segundo, cuidou de deixar explícita a proteção à intimidade e à vida privada. No entendimento de Sandra Lia Simón, a intenção do legislador em detalhar as proteções constitucionais decorreu da sua preocupação em evitar interpretações restritivas, garantindo amplamente, em sob todas as formas de manifestação, a intimidade e a vida privada dos indivíduos. ${ }^{57}$

No âmbito infraconstitucional, o direito à privacidade encontra-se protegido em vários diplomas legais, como no Código Penal no artigo 150, que pró́be a violação de domicílio e no artigo 151, onde há a proibição da violação de correspondência, em especial a violação de comunicação telegráfica, radioelétrica ou telefônica (inciso II do artigo 151). Ainda no Código Penal, o artigo 152 pró́be a divulgação do conteúdo da correspondência comercial e o artigo 153 proíbe a divulgação do conteúdo da correspondência confidencial.

No Código Civil de 2002, os artigos 20 e 21 disciplinam o direito à intimidade que, apesar da referência explícita à intimidade, não está restrito a esta esfera de resguardo, abrangendo todos os domínios da privacidade do indivíduo.

A Lei 4.117, de 27 de agosto de $1962^{58}$, que institui o Código Brasileiro de Telecomunicações, determina, em seu artigo 54 que "é inviolável a telecomunicação nos termos desta lei”. A Lei 6.538/78, que regula os direitos e obrigações concernentes ao Serviço Postal e ao Serviço de Telegrama em todo o território nacional, em seu artigo 41, inciso II, proíbe a divulgação do conteúdo por qualquer pessoa que, em razão do ofício, tenha conhecimento do conteúdo de correspondência alheia. O artigo 10 da Lei 9.296, de 24 de julho de 1996, regulamenta a parte final do artigo $5^{\circ}$ da Constituição Federal e considera crime a interceptação de comunicações telefônicas, de informática ou telemática, sem autorização judicial (requerida para processamento em segredo de justiça, para efeito

\footnotetext{
${ }^{56}$ OLIVEIRA, Paulo Eduardo Vieira. op. cit., p. 92.

${ }^{57}$ SIMÓN, Sandra Lia. op. cit., p. 99.

${ }^{58}$ Revogada parcialmente pela Lei 9.472/97.
} 
de prova em investigação criminal e em instrução processual penal), sob pena de reclusão de dois a quatro anos.

Conforme resta evidenciado através dos dispositivos legais acima indicados, a legislação brasileira constitucional e infraconstitucional proíbe expressamente a invasão da intimidade e da vida privada, considerando crime a violação do sigilo de correspondência e a interceptação de comunicações telefônicas.

A concepção do direito à privacidade pela doutrina possui uma linha evolutiva. Conforme sustenta Danilo Doneda, inicialmente, a compreensão da privacidade foi marcada por um individualismo exacerbado e mesmo egoísta, época em que era conhecida como o "direito a ser deixado só". Posteriormente, surgiu a concepção de que a privacidade é um aspecto fundamental da realização da pessoa e do desenvolvimento de sua personalidade. Atualmente, a privacidade é vista como instrumento importante para a sociedade democrática, como requisito de outras liberdades fundamentais. Hoje, para o autor, a privacidade "compreende algo muito mais complexo do que o isolamento ou a tranquilidade". 59

De fato, a concepção atual da privacidade é mais complexa que a formulada quando da primeira edição do estudo do tema pelos norte-americanos. Ao analisar a obra de Stefano Rodotà, Maria Celina Bodin de Moraes destaca a diferença que este autor faz entre a noção de privacidade tal qual concebida por Warren e Brandeis com o "right to be let alone" e a utilizada atualmente como o "direito à autodeterminação informativa", onde o indivíduo possui real poder sobre as suas informações e dados, mantendo o controle sobre as próprias informações de forma a autodeterminar a construção da sua esfera privada. Ao analisar a forma como o direito à privacidade é concebido por Stefano Rodotà, a autora conclui que "configura-se o direito à privacidade como um instrumento fundamental contra a discriminação, a favor da igualdade e da liberdade". ${ }^{60}$

Stefano Rodotà sustenta que atualmente

não é mais possível considerar os problemas da privacidade somente por meio do pêndulo entre 'recolhimento' e 'divulgação'; entre o homem prisioneiro de seus segredos e o homem que nada tem a esconder; entre a 'casa-fortaleza', que glorifica a privacidade e favorece o egocentrismo, e a 'casa-vitrine', que privilegia as trocas sociais; e assim por diante. Essas

\footnotetext{
${ }^{59}$ DONEDA, Danilo. Da privacidade à proteção de dados pessoais, cit., p. 10.

${ }^{60}$ A consideração consta no texto elaborado por Maria Celina Bodin de Moraes para a apresentação do autor e do livro: MORAES, Maria Celina Bodin de. Apresentação. In: RODOTÀ, Stefano. A vida na sociedade da vigilância. A privacidade hoje. Rio de Janeiro: Renovar, 2008, p. 25.
} 
tendem a ser alternativas cada vez mais abstratas, visto que nelas se reflete uma forma de encarar a privacidade que negligencia justamente a necessidade de dilatar esse conceito para além da sua dimensão estritamente individualista, no âmbito da qual sempre esteve confinada pelas circunstâncias de sua origem. ${ }^{61}$

Em razão da moderna concepção de privacidade, este direito passou a ser estudado e aplicado de forma a garantir a sua tutela em todas as esferas de relacionamento do indivíduo, inclusive nas relações de emprego, conforme será melhor desenvolvido no capítulo 3 do presente trabalho.

\subsection{Limitação à privacidade}

Conforme já visto, o direito à privacidade, como direito da personalidade, possui como uma de suas características a indisponibilidade e a irrenunciabilidade. No entanto, estas qualidades não impedem que esse direito sofra limitações em razão da situação do seu exercício, até mesmo porque não existe direito ilimitado. ${ }^{62}$

Pontes de Miranda reconhece que o direito de velar a privacidade pode ter o seu exercício limitado de acordo com a situação, como por exemplo:

a) Se A tomou parte em acontecimentos que se passaram na sua intimidade, ou outrem foi o agente, havendo interesse de maior relevância na revelação dessa intimidade, até certo ponto; ou se b) Se A mesmo consentiu em que desvelasse essa intimidade. Nestes casos, não existe o direito de velar a intimidade, porque todo o direito é feito de fato jurídico; todo fato jurídico supõe suporte fático. No suporte fático está elemento 'intimidade'; se A consentiu que lhe devassasse a vida privada, a intimidade deixou de existir: o consentimento atuou como préexcludente. $^{63}$

Para o mesmo autor, o direito de velar a privacidade é feito do exercício de fazer e de não fazer. Há liberdade para preservar ou externar.

As limitações à intimidade e as limitações à renúncia a ela são, por conseguinte, concernentes à liberdade da mesma: todos têm de respeitar mínimo de intimidade [...] e ao mesmo tempo ninguém pode ser privado

\footnotetext{
${ }^{61}$ MORAES, Maria Celina Bodin de. op. cit., p. 25

${ }^{62}$ SIMÓN, Sandra Lia. op. cit., p. 80.

${ }^{63}$ MIRANDA, Francisco Cavalcanti Pontes de. op. cit., v. 8, p. 127.
} 
de tal mínimo de intimidade (a penetração na vida privada, com inquéritos e buscas, somente se permite nas espécies previstas em lei) ${ }^{64}$

Para Carlos Alberto Bittar, "limitações existem ao direito à intimidade, em razão de interesses vários da coletividade e pelo desenvolvimento crescente de atividades estatais, como ordens judiciais, policiais". Sustenta que para que o direito à intimidade sofra limitações, faz-se necessário que o direito coletivo predomine sobre o particular, cabendo verificar em cada caso, o alcance específico, de forma a analisar os interesses em jogo. ${ }^{65}$

A limitação da privacidade é justificada por Paulo José da Costa Júnior sob o fundamento de que "o homem, enquanto indivíduo que integra a coletividade, precisa aceitar as delimitações que lhe são impostas pelas exigências da vida em comum. E as delimitações de sua esfera privada deverão ser toleradas tanto pelas necessidades impostas pelo Estado, quanto pelas esferas pessoais dos demais concidadãos". ${ }^{66}$

A limitação ao direito à privacidade é igualmente reconhecida por Sandra Lia Simón, desde que fundamentada no princípio da supremacia do interesse público, citando, como exemplo, questões de segurança nacional e aquelas relacionadas à saúde pública. ${ }^{67}$

A autora também reconhece a anuência do titular como fator que autoriza a invasão na sua privacidade, esclarecendo que consentir não significa transmitir a outrem, nem dispor, nem renunciar. O que diferencia o consentimento destas outras figuras é o seu caráter temporal. Enquanto a renúncia é para sempre, no consentimento o indivíduo opta por temporariamente deixar de exercer o seu direito. E, por fim, conclui "por serem livres, os indivíduos podem, portanto, abrir mão da intimidade e da vida privada". ${ }^{6}$

No que diz respeito à forma do consentimento, Sandra Lia Simón entende que este não precisa ser expresso, podendo ser tácito, bastando que o indivíduo adote atitudes que demonstrem, de forma inequívoca, a sua anuência. No entanto, em razão da característica do consentimento, este não pode ser abrangente, ou seja, valerá apenas para uma situação determinada e não para situações diversas daquelas em que foi admitido. ${ }^{69}$

Liliane Minardi Paesani destaca que existem limites à normal esfera da privacidade, até mesmo contra a vontade do indivíduo, caso ele ocupe posição de relevância pública na

\footnotetext{
${ }^{64}$ MIRANDA, Francisco Cavalcanti Pontes de. op. cit., v. 8, p. 128.

${ }^{65}$ BITTAR, Carlos Alberto. op. cit., p. 108.

${ }^{66}$ COSTA JÚNIOR, Paulo José. op. cit., p. 45.

${ }^{67}$ SIMÓN, Sandra Lia. op. cit., p. 81-83.

${ }^{68}$ Id. Ibid., p. 83.

${ }^{69}$ Id. Ibid., p. 84.
} 
sociedade. Pondera, também, que os interesses coletivos também são fatores limitadores à privacidade (considerados aqueles de maior relevância numa avaliação conjunta do interesse geral). Nas palavras da autora "a predominância do interesse coletivo sobre o particular requer, em cada caso, a verificação do alcance respectivo, a fim de não sacrificar indevidamente a pessoa, salvo quando a divulgação de notícias com finalidades científicas ou de polícia venham a sacrificar o interesse particular em prol da coletividade" ${ }^{70}$

Os artigos 11 e 20 do Código Civil reconhecem, mediante autorização ou previsão em lei, a limitação aos direitos da personalidade e, consequentemente, à privacidade. No âmbito público internacional, o artigo $8^{\circ}$ da Convenção para a Proteção dos Direitos do Homem e das Liberdades Fundamentais também possibilita a limitação da privacidade e restringe este ato para as situações de garantia da segurança nacional, segurança pública, bem-estar econômico do país, defesa da ordem e prevenção de infrações penais, proteção da saúde ou moral ou a proteção de direitos e liberdades de terceiros. ${ }^{71}$

Entendemos que a privacidade do indivíduo pode ser limitada sempre que estiverem em jogo interesses que justifiquem tais limitações e que sejam legítimos e decorrentes de um interesse maior da coletividade. A limitação, nessa hipótese, não representa renúncia ou disponibilidade deste direito, visto que há apenas uma limitação no seu exercício, devendo ser mantido incólume o seu núcleo essencial. Além disso, para garantir a legalidade do ato, a limitação deve sempre estar amparada em lei e contar com o consentimento da parte restringinda.

Cabe verificar, no entanto, se na situação específica do contrato de trabalho é possível constatar o atendimento dos requisitos acima destacados de forma a legitimar a limitação da privacidade do empregado, tendo em vista a dinâmica peculiar da relação de emprego. Para que tal verificação seja realizada de forma completa, antes se faz necessário o estudo da noção de subordinação do empregado e do poder diretivo do empregador, o que ocorrerá no capítulo a seguir.

\footnotetext{
${ }^{70}$ PAESANI, Liliane Minardi. Direito e internet: liberdade de informação, privacidade e responsabilidade civil. São Paulo: Atlas, 2000. p. 48.

${ }^{71}$ Artigo $8 .^{\circ}$ (Direito ao respeito pela vida privada e familiar)

1. Qualquer pessoa tem direito ao respeito da sua vida privada e familiar, do seu domicílio e da sua correspondência.

2. Não pode haver ingerência da autoridade pública no exercício deste direito senão quando esta ingerência estiver prevista na lei e constituir uma providência que, numa sociedade democrática, seja necessária para a segurança nacional, para a segurança pública, para o bem-estar econômico do país, a defesa da ordem e a prevenção das infracções penais, a protecção da saúde ou da moral, ou a protecção dos direitos e das liberdades de terceiros.
} 


\section{O PODER DIRETIVO DO EMPREGADOR}

\subsection{Contrato de trabalho - subordinação}

A definição legal de contrato de trabalho está contida no artigo 442 da Consolidação das Leis do Trabalho, como sendo "o acordo tácito ou expresso, correspondente à relação de emprego". Não satisfeita com o conceito simplista da legislação, a doutrina ampliou e especificou essa definição.

Cesarino Júnior define contrato de trabalho como "a convenção pela qual uma ou várias pessoas físicas se obrigam mediante remuneração, a prestar serviços não eventuais à outra pessoa, sob a direção desta". ${ }^{72}$

Para Orlando Gomes e Elson Gottschalk "contrato de trabalho é a convenção pela qual um ou vários empregados, mediante certa remuneração e em caráter não eventual, prestam trabalho pessoal em proveito e sob a direção de empregador". ${ }^{73}$

O contrato de trabalho para Délio Maranhão é "o negócio jurídico pelo qual uma pessoa física (empregado) se obriga, mediante o pagamento de uma contraprestação (salário), a prestar trabalho não eventual em proveito de outra pessoa, física ou jurídica (empregador), a quem fica juridicamente subordinada". ${ }^{74}$

Dos conceitos acima destacados, além da prestação dos serviços propriamente dita, de sujeição do empregado às ordens do empregador, evidenciado pelo estado de subordinação, é elemento comum para todos os autores.

De fato, o conceito contido no artigo $2^{\circ}$ da Consolidação das Leis do Trabalho ${ }^{75}$ concede ao empregador a prerrogativa de dirigir a prestação pessoal do trabalho. Por sua vez, a compreensão do conceito de empregado extraída da redação do artigo $3^{0}$ da

\footnotetext{
${ }^{72}$ CESARINO JÚNIOR, Antônio Ferreira. Direito social. 2. ed. São Paulo: LTr, 1993. v. 1, p. 123.

${ }^{73}$ GOMES, Orlando; GOTTSCHALK, Elson. Curso de direito do trabalho. 10. ed. Rio de Janeiro: Forense, 1987. p. 144.

${ }^{74}$ SÜSSEKIND, Arnaldo et al. Instituições de direito do trabalho. 21. ed. atualizada por Arnaldo Süssekind e João de Lima Teixeira Filho. São Paulo: LTr, 2003, v. 1, p. 241.

${ }^{75}$ Artigo $2^{\circ}$ Considera-se empregador a empresa, individual ou coletiva, que, assumindo os riscos da atividade econômica, admite, assalaria e dirige a prestação pessoal de serviços. (...) (grifamos).
} 
Consolidação das Leis do Trabalho $^{76}$ aponta a dependência como o elemento mais importante e presente na relação de emprego.

A concepção de dependência ou subordinação deve levar em consideração dois importantes aspectos.

O primeiro diz respeito ao tipo de dependência estabelecida, pois há muito tempo doutrina e jurisprudência concebem a subordinação jurídica como característica da relação de emprego, representada pela capacidade do empregador de comandar e determinar a forma pela qual a atividade será prestada pelo trabalhador. Não mais subsiste a ideia de dependência econômica, técnica ou social como elemento necessário para a caracterização da relação de emprego.

O segundo aspecto diz respeito ao objeto da subordinação. Conforme destaca Arion Sayão Romita, o objeto do contrato de trabalho não é a pessoa do trabalhador, mas sim a sua atividade. Ou seja, é a atividade oferecida que está subordinada ao empregador e não o trabalhador em si. $^{77}$

Em razão de tal concepção, Arion Sayon Romita define subordinação como sendo a “integração da atividade do trabalhador na organização da empresa mediante um vínculo contratualmente estabelecido, em virtude do qual o empregado aceita a determinação, pelo empregador, das modalidades de prestação de trabalho". ${ }^{78}$

Otavio Pinto e Silva, ao analisar o conceito de subordinação de Arion Sayão Romita, destaca que o objeto do contrato de trabalho é atividade do trabalhador, e não o próprio empregado. Adicionalmente, esclarece que o elo que estabelece o relacionamento entre empregado e empregador é a atividade em si, que se exterioriza na relação de emprego. Nas palavras do autor "por ser credor de trabalho, o empregador tem a faculdade de intervir na atividade do empregado. A relação de trabalho envolve obrigação patrimonial de prestação pessoal. A relação imediata é com o trabalho, mas há relação mediata com a pessoa do trabalhador". 79

Paulo Eduardo Vieira de Oliveira pondera que apesar de existir uma relação pessoal entre empregado e empregador, é a atividade e não a pessoa que é objeto da relação

\footnotetext{
${ }^{76}$ Artigo $3^{\text {o }}$ Considera-se empregado toda pessoa física que prestar serviços de natureza não eventual a empregador, sob a dependência deste e mediante salário. (...) (grifamos)

${ }^{77}$ ROMITA, Arion Sayão. Direitos fundamentais nas relações de trabalho. São Paulo: LTr, 2005. p. 187.

${ }^{78}$ Id. A subordinação no contrato de trabalho. Rio de Janeiro: Forense, 1979. p. 82.

${ }^{79}$ SILVA, Otavio Pinto e. Subordinação, autonomia e parassubordinação nas relações de trabalho. São Paulo: LTr, 2004. p. 17.
} 
jurídica estabelecida entre as partes, sendo que colocar-se "sob ordens" implica o dever de obedecer, mas obediência não significa subserviência. ${ }^{80}$

A subordinação não é um status do trabalhador, pois quem está sob o poder do empregador é a atividade; tampouco é uma manifestação de vínculo de hierarquia, visto que neste tipo de relacionamento não há possibilidade de rompimento, o que não acontece na relação de emprego. O empregado, como pessoa, não está submisso ou sujeito pessoalmente ao empregador. ${ }^{81}$

Neste mesmo sentido, mas sob outra perspectiva, Octavio Bueno Magano esclarece que

\begin{abstract}
a situação de subordinação em que se encontra o trabalhador não é permanente, como a do filho em relação à família ou do cidadão, no que concerne ao Estado, mas meramente acidental. A concepção de subordinação está ligada à idéia de empresa, como organização semipública, destinada a desenvolver as atividades econômicas do Estado e servir de instrumento à aquisição do status de homo faber. A deiscência do corporativismo tornou também anacrônica a concepção referida, Melhor se explica a subordinação, não como qualidade inerente ao trabalhador inserido na empresa, mas como mera posição ou situação de fato decorrente da celebração do contrato de trabalho. ${ }^{82}$
\end{abstract}

Concordamos com os quatro autores acima citados, por entender que a subordinação da atividade, ou da forma como o serviço será prestado, não se confunde com a colocação da totalidade da pessoa à disposição do empregador.

Ocorre que, por não ser possível dissociar a figura da atividade exercida da pessoa do próprio trabalhador, tal peculiaridade deve ser considerada na compreensão da subordinação, pois ao emanar ordens no dia a dia, o empregador deve ter em mente o tênue limite entre a atividade que é colocada a sua disposição e a figura do empregado que, por não ser mercadoria, não pode ser utilizada ao seu bel prazer.

Da subordinação decorrem direitos e deveres para empregado e empregador. Segundo Délio Maranhão, seja qual for a forma de trabalho subordinado, o empregador terá o direito de organizar e comandar as condições e a aplicação concreta da forma de

\footnotetext{
${ }^{80}$ OLIVEIRA, Paulo Eduardo Vieira. op. cit., p. 151.

${ }^{81}$ SILVA, Otavio Pinto e. op. cit., p. 17-18.

${ }^{82}$ MAGANO, Octavio Bueno. Do poder diretivo da empresa. São Paulo: Saraiva, 1982. p. 195.
} 
trabalho do empregado; de controlar o cumprimento da prestação do serviço; e de aplicar medidas disciplinares na hipótese de inadimplemento de qualquer obrigação contratual. ${ }^{83}$

A subordinação está diretamente relacionada ao poder diretivo, sendo que estes não existem isoladamente. Na relação de emprego, a subordinação é um lado da moeda, sendo que o poder de direção é o outro, de modo que, sendo o empregado um trabalhador subordinado, está sujeito ao poder diretivo do empregador. ${ }^{84}$

O exercício do poder diretivo não admite a supremacia de um sujeito da relação jurídica sobre outro, visto que, conforme destacado, o que o empregador dirige é a prestação pessoal dos serviços (atividade) e não a pessoa, sendo que o poder de direção é exercido em favor da organização do trabalho e não do atendimento egoístico do seu empregador ou preposto. Não há, portanto, ilimitada sujeição da pessoa do empregado, com o domínio do seu corpo e alma tal qual ocorria no regime escravocrata ou servil. ${ }^{85}$

Vários são os termos utilizados para definir o poder reconhecido pela ordem jurídica ao empregador sobre a atividade do empregado em razão do estado de subordinação decorrente do contrato de trabalho. Parte da doutrina refere-se a poder diretivo $^{86}$, outra parte utiliza do termo poder de direção ${ }^{87}$, poder empregatício ${ }^{88}$, poder hierárquico $^{89}$ ou direito de direção geral ${ }^{90}$.

Para a finalidade da presente dissertação, utilizaremos a expressão poder diretivo.

\footnotetext{
${ }^{83}$ SÜSSEKIND, Arnaldo et al. op. cit., v. 1, p. 243.

${ }^{84}$ NASCIMENTO, Amauri Mascaro. Iniciação ao direito do trabalho. 21. ed. rev. e atual. São Paulo: LTr, 1994. p. 184.

${ }^{85}$ OLIVEIRA NETO, Alberto Emiliano de et al. Vida privada do empregado: revistas íntimas, boa aparência e estética. Aldacy Rachid Coutinho (orientador). Revista da Academia Brasileira de Direito Constitucional, Curitiba, v. 4, p. 145-174, 2003.

${ }^{86}$ SANSEVERINO, Luisa Riva. Curso de direito do trabalho. Tradução de Élson Gottschalk. São Paulo: LTr, 1976. p. 206; CESARINO JÚNIOR, Antônio Ferreira. op. cit., v. 1, p. 132; OLIVEIRA, Paulo Eduardo Vieira de. $O$ dano pessoal no direito do trabalho, cit., p. 153.

${ }^{87}$ NASCIMENTO, Amauri Mascaro. Iniciação ao direito do trabalho. 21. ed. rev. e atual, cit., p. 184; MARTINS, Sérgio Pinto. Direito do trabalho. 19. ed. São Paulo: Atlas, 2004. p. 223; PINTO, José Augusto Rodrigues. Curso de direito individual do trabalho: noções fundamentais de direito individual do trabalho, sujeitos e institutos do direito individual. 4. ed. São Paulo: LTr, 2000. p. 238.

${ }^{88}$ DELGADO, Maurício Godinho. Curso de direito do trabalho. 3 ed. São Paulo: LTr, 2004. p. 628.

${ }^{89}$ BARROS, Alice Monteiro de. Poder hierárquico do empregador. Poder diretivo. In: ___ (Coord.) Curso de direito do trabalho: estudos em memória de Célio Goyatá. 2 ed. rev. atual. e ampl. São Paulo: LTr, 1994. p. 544; MAGANO, Octavio Bueno. Manual de direito do trabalho. 4 ed. São Paulo: LTr, 1993. v. 2.

${ }^{90}$ GOMES, Orlando; GOTTSCHALK, Elson. op. cit., p. 80.
} 


\subsection{O poder diretivo - origem, natureza jurídica e conceito}

Superado o conceito de contrato de trabalho e de subordinação, cumpre-nos apresentar a definição do poder diretivo, pois do seu exercício, em contraposição ao direito de privacidade do empregado, é que chegaremos às conclusões pretendidas no presente trabalho. O estudo do poder diretivo é fundamental, pois quando tratamos de concretização ou limitação da privacidade do trabalhador, é necessário tratar do exercício do poder diretivo, sua origem, natureza jurídica e conceito, o que passamos a fazer a seguir.

\subsubsection{Origem}

Discute-se na doutrina qual a origem ou fonte do poder diretivo, sendo que existem quatro principais teorias desenvolvidas a respeito.

De acordo com a teoria da propriedade privada, o poder de direção tem a sua origem no exercício do direito de propriedade do empregador. É também conhecida como teoria senhorial. O empregador, por ser o detentor dos meios de produção e titular do empreendimento empresarial, tem o poder de organizar, disciplinar e controlar o trabalho do empregado. Ou seja, o empregador comanda e direciona a empresa e a prestação do trabalho porque é dono. Parte-se do pressuposto de que quem detém a propriedade possui o direito exclusivo de usá-la e dela desfrutar.

A corrente que defendia a teoria da propriedade privada predominou nos primórdios do direito do trabalho, reconhecendo um poder quase despótico do proprietário do empreendimento para gerir a produção. ${ }^{91}$

A doutrina atual critica fortemente essa teoria, por representar uma concepção liberal extremada e ultrapassada. A uma, porque ignora que o conceito de propriedade não permaneceu o mesmo em todos os momentos da história, sendo que o moderno conceito de propriedade está atrelado à realização das necessidades humanas, de forma a exercer a sua função social. A duas, por não conseguir absorver a diferença essencial entre as relações de produção escravagista e servis das relações calcadas no trabalho livre da sociedade capitalista industrial moderna. A três, porque, conforme destaca Octavio Bueno Magano,

${ }^{91}$ DELGADO, Maurício Godinho. O poder empregatício. São Paulo: LTr, 1996. p. 165. 
nem sempre a propriedade constitui fundamento do poder diretivo, como o exemplo da empresa que se encontra submetida ao controle minoritário ou gerencial na qual o verdadeiro poder diretivo decorre do controle e não da propriedade. ${ }^{92}$

A teoria institucional concebe a empresa como uma instituição, onde a disciplina do trabalho desenvolvido não deriva do contrato, mas de sua organização interna. Ou seja, a empresa é considerada como uma instituição onde os empregados se inserem de forma organizada e hierarquizada.

José Luiz de Mesquita sustenta que o poder direito como instituição decorre do interesse social da empresa que, para realizar-se, exige perfeita disciplina profissional do trabalho fornecido com a colaboração dos trabalhadores com o objetivo de atingir um bem socioeconômico comum. ${ }^{93}$

Octavio Bueno Magano defende em parte a teoria institucional, sustentando que o vínculo que naturalmente decorre da noção de instituição é o de colaboração, na medida em que empregador e trabalhadores buscam a realização de um objetivo comum. No entanto, sustenta que a teoria institucional deve ser concebida em conjunto com a teoria contratual, pois a afirmação da existência de colaboração não exclui, necessariamente, a oposição de interesses, própria do contrato de trabalho. ${ }^{94}$

A doutrina atual critica, em sua maioria, a teoria institucional. Alice Monteiro de Barros, por exemplo, afirma que essa teoria, que possui um caráter mais político e social do que jurídico, está em franco declínio. ${ }^{95}$ Por sua vez, José Martins Catharino entende que a teoria institucional envolve uma aparente generosidade que não representa a realidade social, tendo em vista que a empresa capitalista não é uma comunidade, não buscando um bem comum sobreposto aos interesses do empregador e dos empregados. ${ }^{96}$

A terceira teoria, denominada teoria contratual, sustenta que o poder diretivo está fundamentado no contrato de trabalho, representado através do acordo de vontades entre empregado e empregador em torno do qual se desenvolvem todas as relações entre ambos.

O contratualismo divide-se em duas fases: a clássica e a moderna. A clássica tenta justificar o contrato de trabalho através dos mesmos tipos contratuais previstos pelo direito

\footnotetext{
${ }^{92}$ MAGANO, Octavio Bueno. Do poder diretivo da empresa, cit., p. 69.

${ }^{93}$ MESQUITA, Luiz José de. Direito disciplinar do trabalho. 2. ed. São Paulo: LTr, 1991. p. 63-64.

${ }^{94}$ MAGANO, Octavio Bueno. Do poder diretivo da empresa, cit., p. 56.

${ }^{95}$ BARROS, Alice Monteiro de. Curso de direito do trabalho. São Paulo: LTr, 2005. p. 553.

${ }^{96}$ CATHARINO, José Martins. O poder disciplinar do empregador e o princípio da ampla defesa. Repertório IOB de Jurisprudência, Rio de Janeiro, n. 24, 2. quinz. dez. 1993.
} 
civil, a saber: o arrendamento, sendo a força de trabalho arrendada pelo capital; a compra e venda, onde o empregado é visto como alguém que vende o seu trabalho por um preço pago pelo empregador, que é o salário; a sociedade, onde há uma combinação de esforços em prol de um objetivo comum que é a produção; e o mandato, sendo o empregado o mandatário do empregador. A moderna sustenta que a natureza contratual sofre grande interferência estatal, de modo que as leis trabalhistas inserem-se automaticamente no contrato, restringindo a autonomia da vontade das partes. Para alguns é uma figura específica, para outros, como Orlando Gomes, é um contrato de adesão, no qual, ao ser admitido, o empregado adere às cláusulas determinadas pelo empregador sem a possibilidade de discuti-las. ${ }^{97}$

A teoria contratual moderna é acolhida pela maior parte da doutrina.

Como exemplo, citamos Orlando Gomes e Elson Gottschalk que entendem, conforme visto acima, que a relação de emprego encontra sua causa determinante no acordo de vontade das partes. ${ }^{98}$ Paulo Eduardo Vieira de Oliveira, ao definir o conceito de subordinação, faz referência ao contrato de trabalho como a sua origem, adotando, consequentemente, a teoria contratual como fonte do poder diretivo. ${ }^{99}$ Alice Monteiro de Barros também entende ser essa teoria a mais consistente para fundamentar a existência dos poderes do empregador no contrato de trabalho, pois é consequência imediata do ajuste pactuado entre empregado e empregador. ${ }^{100}$ Gustavo Filipe Barbosa Garcia ${ }^{101}$ é mais um adepto da teoria contratualista, por entender que está fundamentada na ordem jurídica.

Amauri Mascaro Nascimento acrescenta uma quarta teoria, a do interesse, segundo a qual o poder de direção decorre do interesse do empregador em organizar, controlar e disciplinar o trabalho que remunera, destinado aos fins propostos pelo seu empreendimento. ${ }^{102}$

Filiamo-nos à teoria contratualista, por entender que o contrato de trabalho, como acordo de vontades que é, dá origem ao poder diretivo, sendo através do qual nasce a relação jurídica de trabalho, no qual a subordinação - e, consequentemente, o poder diretivo - é essencial para a sua existência. Quando estabelece o contrato de trabalho - de

\footnotetext{
${ }^{97}$ NASCIMENTO, Amauri Mascaro. Iniciação ao direito do trabalho. 14. ed. São Paulo: LTr, 1989. p. 136. ${ }^{98}$ GOMES, Orlando; GOTTSCHALK, Elson. op. cit., p. 144.

${ }^{99}$ OLIVEIRA, Paulo Eduardo Vieira. op. cit., p. 86.

${ }^{100}$ BARROS, Alice Monteiro de. Curso de direito do trabalho, cit., p. 553.

${ }^{101}$ GARCIA, Gustavo Filipe Barbosa. Curso de direito do trabalho. 2. ed. rev. atual. e ampl. São Paulo: Método, 2008. p. 299.

${ }^{102}$ NASCIMENTO, Amauri Mascaro. Iniciação ao direito do trabalho. 21. ed. rev. e atual., cit., p. 185.
} 
forma tácita ou expressa -, o empregado conscientemente sujeita-se a se colocar sob o poder diretivo do empregador.

Quanto ao acordo de vontade no ajuste contratual, cumpre destacar que ainda que não se possa falar em livre vontade do empregado, posto que se trata de contrato de adesão, há, efetivamente, uma declaração de vontade por parte do trabalhador para a formação do vínculo empregatício, sendo desta manifestação de vontade que decorre o poder diretivo. Nesse sentido, concordamos com a posição de Oris de Oliveira de que "a adesão consciente do empregado se impõe a partir do momento do surgimento da relação de emprego, por mais condicionada que seja pelas forças de produção, por injunções do mercado de trabalho". ${ }^{103}$

\subsubsection{Natureza jurídica}

A natureza jurídica do poder diretivo é explicada por três vertentes da doutrina.

A primeira corrente define a natureza jurídica como um direito potestativo, ou seja, um direito-poder, exercido de forma unilateral, cuja destinação é influir sobre a relação jurídica existente, determinando o conteúdo das prestações das partes. Trata-se de uma prerrogativa do titular, que poderá utilizá-la como e quando lhe bem prouver, produzindo efeitos imediados. Manuel Alonso Olea é um dos representantes desta corrente, sustentando que "o poder de direção é a faculdade, ou direito potestativo, conferido ao empresário pelo contrato de trabalho, de dar ordens sobre o modo, o tempo e o lugar de execução do trabalho". ${ }^{104}$

Amauri Mascaro Nascimento critica esta teoria, sob o fundamento de não ser possível aplicá-la em razão da amplitude dos poderes que se confere ao empregador. ${ }^{105}$

A segunda corrente consiste na consideração do poder diretivo como direito subjetivo do empregador em face do empregado. Trata-se, portanto, de um poder conferido à vontade do titular para concretizar os seus interesses de acordo com a ordem jurídica, sendo que a atuação do titular fica restrita às normas legais ou contratuais pré-existentes. Há, no caso, vontade do empregado de dar cumprimento à obrigação - em razão dos

\footnotetext{
${ }^{103}$ OLIVEIRA, Oris. A pessoalidade no contrato individual de trabalho. Revista Legislação do Trabalho e Previdência Social, São Paulo, v. 38, n. 2, p. 118-122, fev. 1974.

${ }^{104}$ ALONSO OLEA, Manuel. Derecho del trabajo. Madrid: Universidad de Madrid, 1980. p. 246.

${ }^{105}$ NASCIMENTO, Amauri Mascaro. Iniciação ao direito do trabalho. 21. ed. rev. e atual., cit., p. 185.
} 
serviços contratados - realizando a prestação em favor do empregado, sempre que de acordo com a ordem jurídica.

Roberto Vieira de Almeida Rezende critica essa concepção, por não conseguir afastar o caráter assimétrico da relação de emprego, também não conseguindo abarcar as novas realidades sociais onde o poder diretivo é exercido de forma mais equânime, como no caso da participação dos trabalhadores na empresa. ${ }^{106}$

A terceira corrente confere ao poder de direção natureza de direito-função, que é a imposição do exercício de uma função pela norma jurídica a alguém, com o que o titular do direito passa a ter obrigações. ${ }^{107}$ É um poder atribuído ao titular para tutelar interesse alheio e não interesse próprio, implicando a existência de obrigações para o próprio titular. Nesta definição, a participação do empregado nas decisões da empresa aumenta, limitandose a amplitude do poder patronal de direção, a ponto de se transformar em conjunto de deveres do empregador para com os seus empregados.

Octavio Bueno Magano entende que a concepção do poder diretivo como direito potestativo se justifica sob uma perspectiva egoísta do empregador de gerir a empresa em seu benefício exclusivo. No entanto, em razão das limitações que o próprio poder diretivo sofreu e em diante do fato de a empresa ter se tornado um centro de convergência de interesses (do próprio empresário, dos administradores, da coletividade, dos trabalhadores), hoje ele não pode ser concebido como direito potestativo, mas sim como direito-função, pois é exercido pelo empregador não no seu interesse exclusivo, mas tendo em vista também o interesse da comunidade de empregados. De qualquer forma, o autor ressalva que "por mais que se assinale o divórcio entre o interesse do empresário e o da empresa, decorrente da transformação da última num centro de convergência de múltiplos interesses, o exercício do poder diretivo, concebido como direito-função, constitui sempre uma prerrogativa do empregador. ${ }^{108}$

Segundo Alice Monteiro de Barros, a teoria que defende a natureza de direitofunção do poder de direção está "em consonância com a função social do contrato, reconhecida pelo artigo 421 do Código Civil de 2002, aplicável subsidiariamente ao Direito do Trabalho por força do art. $8^{\circ}$ da CLT". Entende, ainda, que a função social

\footnotetext{
${ }^{106}$ REZENDE, Roberto Vieira de Almeida. Delineamento constitucional do poder diretivo. 2004. Tese (Doutorado) - Faculdade de Direito, Universidade de São Paulo, São Paulo, 2004, p. 28.

${ }^{107}$ NASCIMENTO, Amauri Mascaro. Iniciação ao direito do trabalho. 21. ed. rev. e atual., cit., p. 185.

${ }^{108}$ MAGANO, Octavio Bueno. Do poder diretivo da empresa, cit., p. 29-30 e 65.
} 
mitiga o princípio da autonomia contratual, e conclui que em razão de o poder diretivo emanar do contrato, esse deverá ser exercido com restrições. ${ }^{109}$

Maurício Godinho Delgado critica as concepções clássicas apontadas acima, propondo uma nova concepção da natureza jurídica do poder diretivo como sendo uma relação jurídica contratual complexa. Para o autor, o poder de direção seria "uma relação jurídica contratual complexa, plástica e de assimetria variável entre empregador e empregado, considerados em sua projeção individual e coletiva, mediante a qual se prevêem, alcançam ou sancionam condutas no plano do estabelecimento e da empresa". ${ }^{110}$

Acolhemos a posição adotada por Maurício Godinho Delgado, por entender que o direito potestativo, o direito subjetivo, tampouco o direito-função, justificam de forma satisfatória a natureza jurídica do poder diretivo, visto que consideram concepções históricas da relação de emprego que atualmente não mais se aplicam. Entendemos que o poder de direção, compreendido como uma relação jurídica contratual complexa, além de confirmar a origem contratual desse poder, abrange tanto as relações mais assimétricas e rígidas da relação de emprego, quanto as situações mais democráticas e igualitárias que se construíram em algumas organizações empresariais.

\subsubsection{Conceito}

A origem etimológica do vocábulo "poder" decorre do latim "potere", da raiz "poti", que significa "senhor de", chefe de um grupo. ${ }^{111}$ Está, portanto, intimamente ligado à ideia de posse, obediência e relação de autoridade entre pessoas de diferentes graus em uma escala hierárquica. Octávio Bueno Magano, apesar de constatar que, de uma verificação sumária sobre o significado de poder decorre a ideia de posse, força, vontade, obediência e influência, afasta estes conceitos iniciais para definir poder como "relação humana manifestada em conduta de adesão". ${ }^{112}$

Apesar de, em uma primeira aproximação com a matéria, poder-se afirmar que o poder diretivo constitui uma das ramificações de poder lato sensu, entendemos este poder como capacidade da pessoa, no sentido de ser a extensão dada aos poderes de ação do

\footnotetext{
${ }^{109}$ BARROS, Alice Monteiro de. Curso de direito do trabalho, cit., p. 554.

${ }^{110}$ DELGADO, Maurício Godinho. Curso de direito do trabalho, cit., p. 656-657.

${ }^{111}$ TORRINHA, Francisco. Dicionário latino português. 7. ed. Porto: Gráficos Reunidos, 1999. p. 667.

${ }^{112}$ MAGANO, Octavio Bueno. Do poder diretivo da empresa, cit., p. 5.
} 
indivíduo reconhecido pela ordem jurídica como a aptidão para contrair direitos e exercer obrigações. $^{113}$

A Consolidação das Leis do Trabalho não trata de forma específica do poder diretivo do empregador, sendo que o seu conceito deve ser extraído da definição de empregador contida no seu artigo $2^{\circ}$, conforme mencionado anteriormente.

Diante da ausência de definição legal, cumpre-nos verificar o conceito de poder diretivo para a doutrina, cabendo registrar que em razão das diversas concepções sobre origem e natureza jurídica, não há um consenso sobre a sua definição jurídica.

Manuel Alonso Olea considera que o poder diretivo constitui uma faculdade ou direito potestativo que é conferido ao empregador pelo contrato de trabalho, que pode dar ordens sobre o modo, o tempo e o lugar da execução do trabalho. ${ }^{114}$

Poder diretivo para Luiz José de Mesquita é "a faculdade em virtude da qual o sujeito ativo, o empreendedor, exerce o direito-função de ditar ordens ao sujeito passivo, o empregado, segundo o interesse social da empresa, para que haja uma perfeita organização profissional e ordem no serviço". 115

Amauri Mascaro Nascimento define poder de direção como "a faculdade atribuída ao empregador de determinar o modo como a atividade do empregado, em decorrência do contrato de trabalho, deve ser exercida" 116

No conceito de Luísa Riva Sanseverino, poder diretivo “consiste na faculdade, para o empregador, de determinar as regras de caráter predominantemente técnicoorganizativas, que o trabalhador deve observar no cumprimento da prestação" ${ }^{117}$.

Para Octavio Bueno Magano, trata-se de uma capacidade, oriunda do direito subjetivo do empresário, ou então da organização empresarial, para determinar a estrutura técnica e econômica da empresa e dar conteúdo concreto à atividade do empregado, visando a realização das finalidades da empresa. ${ }^{118}$

Paulo Eduardo Vieira de Oliveira inspira-se no conceito de Magano, ampliando a sua aplicação para todas as relações de trabalho, definindo poder diretivo como sendo "a

\footnotetext{
${ }^{113}$ MAGANO, Octavio Bueno. Do poder diretivo da empresa, cit., p. 29.

${ }^{114}$ ALONSO OLEA, Manuel. op. cit., p. 262.

${ }^{115}$ MESQUITA, Luiz José de. op. cit., p. 65.

${ }^{116}$ NASCIMENTO, Amauri Mascaro. Iniciação ao direito do trabalho. 21. ed. rev. e atual., cit., p. 184.

${ }^{117}$ SANSEVERINO, Luisa Riva. op. cit., p. 207.

${ }^{118}$ MAGANO, Octavio Bueno. Do poder diretivo da empresa, cit., p. 94.
} 
capacidade de determinar a estrutura técnica, econômica e administrativa da empresa, em função dos objetivos propostos". 119

Maurício Godinho Delgado utiliza o termo poder empregatício, e o conceitua como “o conjunto de prerrogativas asseguradas pela ordem jurídica e tendencialmente concentradas na figura do empregador, para exercício no contexto da relação de emprego."120

Para Sandra Lia Simón, o "poder de direção é a prerrogativa que o empregador possui de determinar a forma pela qual ocorrerá a prestação de serviços, por parte do empregado". ${ }^{121}$

Gustavo Filipe Barbosa Garcia entende o poder diretivo como sendo aquele que autoriza o empregador a organizar, controlar e disciplinar a prestação de serviço do empregado que ocorre de forma subordinada. ${ }^{122}$

De posse dos conceitos apresentados pela doutrina, é possível afirmar que poder diretivo é uma capacidade do empregador, decorrente do contrato de trabalho, de organizar a estrutura empresarial e, por consequência, determinar a forma pela qual o serviço será prestado pelo trabalhador. O titular do poder diretivo é o empregador, que o exerce diretamente ou por intermédio de prepostos, a quem delega em parte este poder.

\subsection{Fundamento legal e constitucional do poder diretivo}

Conforme visto acima, apesar de inexistir um conceito expresso sobre poder diretivo na legislação, podemos afirmar, partindo da sua origem na teoria contratual, que o seu fundamento legal pode ser extraído da redação do artigo 442 da Consolidação das Leis do Trabalho, que define o conceito de contrato de trabalho e, principalmente, dos artigos $2^{\circ}$ e $3^{\circ}$ da Consolidação das Leis do Trabalho, os quais concedem ao empregador a prerrogativa de dirigir a prestação pessoal do trabalho e estabelecem a subordinação jurídica da atividade do empregado.

\footnotetext{
${ }^{119}$ OLIVEIRA, Paulo Eduardo Vieira. op. cit., p. 155.

${ }^{120}$ DELGADO, Maurício Godinho. Curso de direito do trabalho, cit., p. 628-629.

${ }^{121}$ SIMÓN, Sandra Lia. op. cit., p. 105.

${ }^{122}$ GARCIA, Gustavo Filipe Barbosa. op. cit., p. 298.
} 
No âmbito constitucional, em razão de o empregador desenvolver uma atividade econômica em caráter privado, detendo os meios de produção e assumindo os riscos do negócio, ainda que não se adote a teoria da propriedade privada como fonte do poder diretivo $^{123}$, não há como negar que as normas fundamentais e os princípios garantidores da livre iniciativa econômica, da liberdade de organização e do direito de propriedade justificam, no âmbito constitucional, a prerrogativa do empregador de dirigir a força de trabalho do empregado.

A elevação da livre iniciativa como um dos fundamentos da República (inciso IV do artigo $1^{\text {o124}}$ ) e como um dos princípios da ordem econômica (caput do artigo $170^{125}$ ) somando a este princípio a propriedade privada dos meios de produção, dotada de uma função social e articulada com a valorização do trabalho humano - indica a intenção do constituinte em colocar a empresa como o centro da atividade econômica. A atividade empresarial exerce, portanto, papel fundamental na ordem econômica.

A livre iniciativa deve ser vista como liberdade de empresa, porquanto a Constituição garante o livre acesso ao mercado e o livre exercício das atividades empresariais, acarretando, portanto, na liberdade de criação, desenvolvimento, organização e direção da entidade produtiva. O poder diretivo, nesse contexto, apresenta-se como uma concretização da liberdade de iniciativa econômica no âmbito do direito do trabalho, por desempenhar um papel decisivo na condução interna do empreendimento empresarial. ${ }^{126} \mathrm{~A}$ livre iniciativa delineia o exercício do poder diretivo, sendo um dos fundamentos constitucionais do poder empresarial na relação de emprego.

A concepção da livre iniciativa, conforme destaca Roberto Vieira de Almeida Rezende, alicerçado no posicionamento de Eros Roberto Grau, "ao ser enunciada pelo art. $1^{\mathrm{o}}$, inciso IV do texto constitucional como um dos alicerces da República, o foi no sentido

\footnotetext{
${ }^{123}$ Conforme esclarecido no item que discorre sobre a origem do poder diretivo, várias são as teorias que o justificam, sendo que a teoria da propriedade privada é a que sofre mais críticas da doutrina.

${ }^{124}$ Art. $1^{\circ}$. A República Federativa do Brasil, formada pela união indissolúvel dos Estados e Municípios e do Distrito Federal, constitui-se em Estado Democrático de Direito e tem como fundamentos: (...)

IV - os valores sociais do trabalho e da livre iniciativa; (...)

${ }^{125}$ Art. 170. A ordem econômica, fundada na valorização do trabalho humano e na livre iniciativa, tem por fim assegurar a todos existência digna, conforme os ditames da justiça social, observados os seguintes princípios: (...)

II - propriedade privada;

III - função social da propriedade;

IV - livre concorrência; (...)

VIII - busca do pleno emprego; (...)

Parágrafo único. É assegurado a todos o livre exercício de qualquer atividade econômica, independentemente de autorização de órgãos públicos, salvo nos casos previstos em lei.

${ }^{126}$ REZENDE, Roberto Vieira de Almeida. op. cit., p. 128-129.
} 
de ser destacado seu valor social. Portanto, não mais se reveste a livre iniciativa como expressão do individualismo, devendo ser tomada no que produz de socialmente valioso.",127

No mesmo sentido, o artigo 170 da Constituição impõe que a livre iniciativa deve assegurar a vida digna, buscando a justiça social, sendo a valorização do trabalho humano essencial para a consecução deste objetivo. Em razão de tal aspecto, apesar de a livre iniciativa legitimar, no plano constitucional, o exercício do poder de direção, também atua como limitação para a sua atuação, visto que sempre deverá ser exercida para a valorização do trabalho e, por via de consequência, do trabalhador. ${ }^{128}$

O poder diretivo, portanto, não poderá ser exercido visando atender ao interesse único do empregador, pois a sua atividade econômica deverá produzir um resultado socialmente valioso (vida digna e justiça social). ${ }^{129}$

No que diz respeito ao direito de propriedade, embora este não seja um fundamento imediato do poder diretivo, constitui um fundamento secundário e influenciador do seu exercício.

A Constituição Federal concebe nos incisos XXII e XXIII do seu artigo $5^{\mathrm{o} 130}$ o direito de propriedade e sua função social como garantias fundamentais. Por sua vez, a propriedade privada e a respectiva função social constituem um dos princípios da ordem econômica, conforme disposto no artigo 170 da Constituição Federal.

A atual concepção da proteção constitucional do direito de propriedade é ampla e abarca todos os meios de produção pertencentes ao empregador e que se materializam na empresa, no estabelecimento, no imóvel onde se localiza o empreendimento, nos bens que compõem esse estabelecimento (tais como maquinário, mobiliário), no modo de produção, nas invenções, nas estratégias de atuação no mercado, no produto, etc. ${ }^{131}$

Roberto Vieira de Almeida Rezende utiliza os ensinamentos de Umberto Romagnoli para sustentar que a propriedade privada autoriza, ainda que indiretamente, o

\footnotetext{
${ }^{127}$ REZENDE, Roberto Vieira de Almeida. op. cit., p. 130.

${ }^{128}$ Id. Ibid., p. 131-133.

${ }^{129}$ Id., loc. cit.

${ }^{130}$ Art. $5^{\circ}$. Todos são iguais perante a lei, sem distinção de qualquer natureza, garantindo-se aos brasileiros e aos estrangeiros residentes no País a inviolabilidade do direito à vida, à liberdade, à igualdade, à segurança e à propriedade, nos termos seguintes: (...)

XXII - é garantido o direito de propriedade;

XXIII - a propriedade atenderá a sua função social; (...)

${ }^{131}$ SIMÓN, Sandra Lia. op. cit., p. 116-117.
} 
controle das modalidades concretas do trabalho desenvolvido pelos produtores imediatos, ou seja, os trabalhadores e a orientação da atividade produtiva. A garantia da propriedade privada também justifica a adoção de ações patronais para a defesa de seu próprio patrimônio no curso da relação de emprego. ${ }^{132}$

O direito de propriedade sofre limitações, como qualquer direito, ainda que integrante das garantias fundamentais. Estas limitações advêm da própria Constituição ou da legislação ordinária. No âmbito constitucional, a função social é o principal fator limitador à propriedade, pois esta última somente terá proteção constitucional nas hipóteses em que atender à sua função social. Trata-se de uma limitação de ordem interna, inerente ao próprio direito. ${ }^{133}$

Segundo José Afonso da Silva, não há como escapar ao sentido de que só garante o direito da propriedade que atenda sua função social ${ }^{134}$. Para o autor

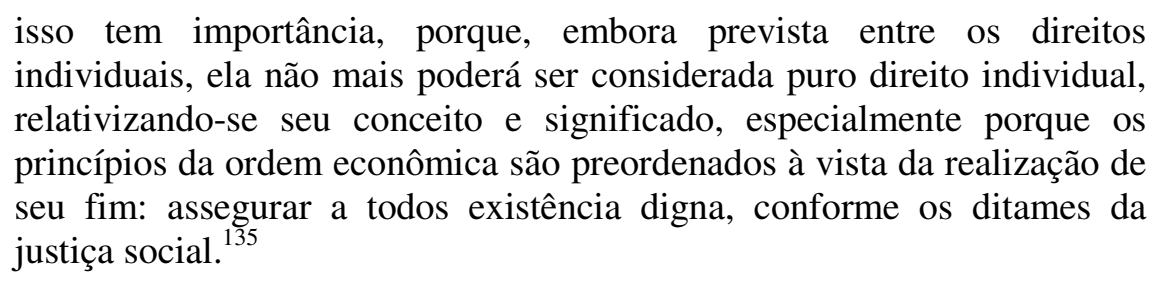

Luisa Riva Sanseverino, em obra traduzida no Brasil em 1903, já destacava a importância do artigo 41 da Constituição italiana no sentido de condicionar a liberdade da iniciativa econômica privada ao respeito da segurança, liberdade e dignidade humana. ${ }^{136}$

O direito de propriedade, portanto, deve compatibilizar-se com a sua função social, devendo haver uma perfeita sintonia entre a fruição individual do bem e o alcance da sua função social. $^{137}$

Ingo Wolfgang Sarlet vai além e concebe o direito de propriedade - inclusive e especialmente em razão do seu conteúdo social consagrado na Constituição - como dimensão inerente à dignidade da pessoa, considerando que a falta de um espaço digno

\footnotetext{
${ }^{132}$ REZENDE, Roberto Vieira de Almeida. op. cit., p. 204.

${ }^{133}$ SIMÓN, Sandra Lia. op. cit., p. 114.

${ }^{134}$ SILVA, José Afonso da.op. cit., p. 244.

${ }^{135}$ Id. Ibid., p. 245.

${ }^{136}$ SANSEVERINO, Luisa Riva. op. cit., p. 251.

${ }^{137}$ BASTOS, Celso Ribeiro. op. cit., p. 210.
} 
para o exercício da atividade profissional, em muitos casos, compromete seriamente os pressupostos básicos para uma vida com dignidade. ${ }^{138}$

Diante das limitações estabelecidas pela própria Constituição, temos que o exercício do poder diretivo fundamentado na livre iniciativa e no direito de propriedade sempre deverá buscar a valorização do trabalho humano de forma a produzir vida digna e justiça social.

\subsection{Exteriorização ou dimensões do poder diretivo}

O poder diretivo é exteriorizado pelo empregador sob três aspectos, a saber: poder de organização, poder de controle ou fiscalização e poder disciplinar. Esta divisão é utilizada, dentre outros, por Amauri Mascaro Nascimento, ${ }^{139}$ Nei Frederico Cano Martins e Marcelo José Ladeira Mauad, ${ }^{140}$ Alice Monteiro de Barros ${ }^{141}$ e Paulo Eduardo Vieira de Oliveira $^{142}$.

O poder de organização se traduz no direito do empregador em determinar a organização dos meios de produção, fixando a forma como o trabalho será prestado pelos empregados, distribuindo tarefas, definindo horário e local de trabalho, etc. Este poder consiste na capacidade de o empresário determinar a estrutura técnica e econômica da empresa, bem como definir a estratégia necessária à realização dos objetivos desta. ${ }^{143}$

Em razão de o empregador deter os meios de produção e, principalmente, assumir os riscos do negócio, nada mais natural que lhe seja autorizado determinar a forma como o negócio será desenvolvido.

O poder de organização, também conhecido como poder diretivo propriamente dito ou poder de direção stricto sensu, decorre da obrigação do empresário de organizar o capital e o trabalho, fatores necessários para a produção de bens e para a prestação de serviços. Este poder, nas palavras de Godinho Delgado é "o conjunto de prerrogativas tendencialmente concentradas no empregador dirigidas à organização da estrutura e espaço

\footnotetext{
${ }^{138}$ SARLET, Ingo Wolfgang. op. cit., p. 97.

${ }^{139}$ NASCIMENTO, Amauri Mascaro. Iniciação ao direito do trabalho. 21. ed. rev. e atual., cit., p. 185-189.

${ }^{140}$ MARTINS, Nei Frederico Cano; MAUAD, Marcelo José Ladeira. Lições de direito individual do trabalho. São Paulo: LTr, 2002. p. 79.

${ }^{141}$ BARROS, Alice Monteiro de. Poder hierárquico do empregador. Poder diretivo, cit.

${ }^{142}$ OLIVEIRA, Paulo Eduardo Vieira. op. cit., p. 153.

${ }^{143}$ MAGANO, Octavio Bueno. Do poder diretivo da empresa, cit., p. 99.
} 
empresariais internos, inclusive o processo de trabalho adotado no estabelecimento e na empresa, com a especificação e orientação cotidianas no que tange à prestação de serviços". 144

Do poder de organização decorre a faculdade de o empregador escolher a atividade a ser desenvolvida, a natureza jurídica do empreendimento, a determinação dos cargos e funções necessárias para o desenvolvimento da atividade, o direito de elaborar o regulamento da empresa, contendo normas especialmente disciplinares a que se sujeitarão os empregados. ${ }^{145}$

O poder de organização justifica-se em razão do controle jurídico que o empregador possui sobre o conjunto da estrutura empresarial, e da assunção dos riscos do negócio que desenvolve.

A maioria da doutrina entende que o poder regulamentar nada mais é do que uma das expressões do poder de organização, visto que no regulamento o empregador define as regras organizacionais da empresa e as regras gerais de conduta dos empregados. Como exceção, Maurício Godinho Delgado concebe o poder regulamentar como um desdobramento autônomo do poder diretivo. Para o autor, o poder regulamentar constitui "o conjunto de prerrogativas tendencialmente concentradas no empregador dirigidas à fixação de regras gerais a serem observadas no âmbito do estabelecimento e da empresa". 146

No nosso entendimento, o poder regulamentar não representa uma modalidade autônoma de exteriorização do poder diretivo, mas, sim, um desdobramento do poder de organização, pois a fixação de normas internas do estabelecimento não deixa de ser uma forma de definir e organizar a forma da prestação do serviço.

O poder de controle autoriza o empregador a fiscalizar a prestação dos serviços, para verificar se o que foi determinado mediante o exercício do poder de organização está sendo cumprido. Também conhecido como poder de fiscalização, resulta no direito que tem o empregador de fiscalizar as atividades de seus empregados no âmbito da relação de trabalho. Nas palavras de Amauri Mascaro Nascimento “justifica-se, uma vez que sem

\footnotetext{
${ }^{144}$ DELGADO, Maurício Godinho. Curso de direito do trabalho, cit., p. 631.

${ }^{145}$ NASCIMENTO, Amauri Mascaro. Iniciação ao direito do trabalho. 21. ed. rev. e atual., cit., p. 185-186.

${ }^{146}$ DELGADO, Maurício Godinho. Curso de direito do trabalho, cit., p. 631-632.
} 
controle, o empregador não pode ter ciência de que, em contrapartida ao salário que paga, vem recebendo os serviços dos empregados". ${ }^{147}$

O poder de controle é um aspecto instrumental do poder de direção, pois não faria sentido existir o poder de dar ordens ou instruções sem a possibilidade de se conferir se essas ordens ou instruções foram corretamente acatadas pelos trabalhadores. ${ }^{148}$

Mais do que uma prerrogativa, o poder de controle ou fiscalização deve ser também considerado como uma obrigação do empregador. Isso porque, a teor do que determina o inciso III do artigo 932 do Código Civil ${ }^{149}$, o empregador é responsável pela reparação civil dos danos decorrentes dos atos praticados por seus empregados, serviçais e prepostos no exercício das atividades relacionadas ao emprego. Tal responsabilidade (objetiva) decorre do exercício do poder diretivo do empregador e do estado de subordinação da atividade do empregado, sendo, também, justificada pela assunção da atividade econômica por parte do empresário, atraindo para si os riscos do empreendimento. Justifica-se, também, pela culpa in eligendo ou culpa in vigilando empresarial.

Sobre a responsabilidade objetiva do empregador, Paulo Eduardo Vieira de Oliveira sustenta que

o fundamento da responsabilidade por fato de terceiro reside na culpa in eligendo ou na culpa in vigilando, dependendo do caso. Dessa forma, uma pessoa pratica o dano, e outra por ela responsável é que tem a obrigação de indenizá-lo, uma vez que não exerceu de forma correta o dever de fiscalização e vigilância sobre aquelas, invocando-se para tanto, a presunção júris tantum de culpa do agente. ${ }^{150}$

Assim, mais do que poder, o empregador tem o dever de fiscalizar os atos praticados pelos seus empregados enquanto estes estiverem sob as ordens e sob a responsabilidade daquele. $\mathrm{O}$ dever de fiscalização visa evitar que o empregado, utilizando de forma indevida os meios de produção fornecidos pelo empregador, cause prejuízo a terceiros, sejam eles integrantes ou alheios à relação de emprego.

\footnotetext{
${ }^{147}$ NASCIMENTO, Amauri Mascaro. Iniciação ao direito do trabalho. 21. ed. rev. e atual., cit., p. 187.

${ }^{148}$ GOMES, Júlio Manuel Vieira. op. cit., v. 1, p. 320-321.

${ }^{149}$ Artigo 932 São também responsáveis pela reparação civil:

(...)

III - o empregador ou comitente, por seus empregados, serviçais e prepostos, no exercício do trabalho que lhes competir, ou em razão dele. (...)

${ }^{150}$ OLIVEIRA, Paulo Eduardo Vieira. op. cit., p. 62.
} 
O poder disciplinar traduz a capacidade do empregador de aplicar sanções disciplinares ao empregado que não observou as regras fixadas em lei, em norma coletiva, no contrato de trabalho ou em regras internas.

Existem duas correntes doutrinárias no que diz respeito ao poder disciplinar.

A primeira nega este poder ao empregador, sob o fundamento de que sendo a relação de emprego um contrato entre dois sujeitos, se um deles pode, o outro também poderia exercer o mesmo poder. Outro fundamento está no monopólio do direito de poder de punir (poder de polícia), que seria privativo do Estado, não podendo ser ampliado para a relação entre particulares. Segundo o entendimento ora exposto, somente o poder público estaria investido na prerrogativa de punir através de seus órgãos.

Por outro lado, há uma segunda corrente que reconhece que o poder disciplinar do empregador está fundamentado nos mesmos argumentos que justificam o poder de direção: a teoria da propriedade privada, a teoria contratual e a teoria institucional. ${ }^{151}$

Filiamos-nos a segunda corrente e reconhecemos o exercício do poder disciplinar, sem confundir essa prerrogativa com o exercício do poder de polícia. O exercício desse poder representa uma forma de autotutela privada de caráter ativo, eis que possui uma função reativa, pois indica a disposição do empregador de reagir contra um descumprimento das ordens dadas ao empregado emanadas da execução do próprio contrato de trabalho.

Alice Monteiro de Barros assevera que a manifestação do poder disciplinar é necessária, também, em razão da inaplicabilidade, em certos casos, dos mecanismos tradicionais de resolução do contrato por descumprimento da obrigação pela outra parte e de indenização pelos danos. Muitas vezes, a falta praticada pelo empregado é leve, não se justificando uma reação extrema, como é a rescisão do contrato. Por sua vez, a indenização pelos danos revela-se, em geral, ilusória, eis que o empregado, normalmente, não possui capacidade econômica para suportar esse ônus e ressarcir o empregador. ${ }^{152}$

Cumpre esclarecer que, no exercício do poder disciplinar, a penalidade limita-se ao domínio do direito do trabalho, pois não se confunde com a penalidade na esfera criminal.

As penalidades aplicáveis ao empregado compreendem a advertência, suspensão e despedida por justa causa. A legislação limita o exercício desse poder disciplinar, não

\footnotetext{
${ }^{151}$ NASCIMENTO, Amauri Mascaro. Iniciação ao direito do trabalho. 21. ed. rev. e atual., cit., p. 188.

${ }^{152}$ BARROS, Alice Monteiro de. Curso de direito do trabalho, cit., p. 569.
} 
sendo permitido, como caráter punitivo, a transferência, a suspensão disciplinar por mais de 30 dias, o rebaixamento ou a redução salarial, tampouco a cominação de multa, exceto para os atletas profissionais, por força da Lei $\mathrm{n}^{\circ} 9.615$, de $1998 .{ }^{153}$

Ao empregado sempre deverá ser assegurado o direito de defesa na aplicação de sanções disciplinares por parte do empregador, independente da sua natureza. Caso o empregado não concorde com a penalidade imposta, poderá se recusar a assinar o documento que formaliza a aplicação da penalidade. De igual forma, o trabalhador poderá solicitar a interferência do seu sindicato de classe, a fim de evitar condutas abusivas do empregador na aplicação das penalidades. No entanto, na maioria das vezes, o que se observa é que o questionamento das penalidades impostas pelo empregador ao trabalhador acaba ocorrendo apenas após a rescisão do contrato de trabalho, na esfera judicial.

O direito de resistência do empregado às ordens, fiscalizações e, principalmente, punições do empregador será estudado a seguir, quando tratarmos das limitações ao poder diretivo.

\subsection{Limitações ao poder diretivo}

O exercício do poder diretivo não é ilimitado, pois o simples fato de o empregado estar subordinado juridicamente ao empregador não confere a este último o direito de fiscalizar, controlar e disciplinar de forma indiscriminada a prestação dos serviços.

O empregado não é um objeto, uma "coisa" ou uma máquina que vende a sua força de trabalho, mas é uma pessoa como qualquer outra, dotada de valores sociais e de dignidade. É tendo essa premissa como ponto de partida que entendemos que o exercício do poder diretivo não é ilimitado, sendo que o seu exercício por parte do empregador deve ser restrito, principalmente, para o respeito da dignidade do trabalhador. Ou seja, o respeito à dignidade da pessoa humana do trabalhador é o ponto de partida para o estabelecimento dos limites básicos do poder diretivo empresarial.

\footnotetext{
${ }^{153}$ No que diz respeito ao atleta profissional, quando ficar impedido de atuar por sua própria e exclusiva responsabilidade, o empregado poderá deixar de receber salário durante o prazo do impedimento ou do cumprimento da pena. Quanto à aplicação de penalidade pecuniária ao atleta, a pena não poderá exceder de $40 \%$ do seu salário.
} 
As limitações ao poder diretivo são impostas pela necessidade de proteção do empregado contra possíveis abusos por parte do empregador, em razão da posição de desvantagem que o trabalhador ocupa na relação contratual.

A maioria da doutrina classifica os limites do poder diretivo em externos e internos.

Os limites externos decorrem da ordem jurídica geral - Constituição Federal ou outras leis -, das normas coletivas aplicáveis às partes, de decisões judiciais e de decisões administrativas. Paulo Eduardo Vieira de Oliveira também inclui como limite externo a moral, pois apesar de não expresso em lei, o exercício do poder diretivo deverá respeitar a moral e os bons costumes vigentes na localidade da prestação de serviços. ${ }^{154}$

Para Octavio Bueno Magano, os limites externos indicam que o poder diretivo não equivale a qualquer supremacia do empregador sobre o empregado. ${ }^{155} \mathrm{O}$ empregado não está obrigado a cumprir ordens ilícitas, sendo que nesses casos o empregado tem o dever de desacatar a ordem patronal, sob pena de incorrer em sanção penal.

No que diz respeito à lei como limite externo, merece destaque, em razão do objeto do presente trabalho, a Constituição Federal com suas normas e princípios constitucionais e, especialmente, os direitos fundamentais, que não cedem inteiramente diante do poder diretivo do empregador. O direito de personalidade, como espécie de direito fundamental, atua, portanto, como limitador ao exercício do poder diretivo patronal. Em especial, a garantia da privacidade do trabalhador como direito limitador ao poder de direção do empregador será objeto de análise mais detalhada nos capítulos 3 e 4 do presente trabalho.

A consagração constitucional da valorização do trabalho humano ${ }^{156}$ também deve ser considerada como uma limitação ao poder diretivo do empregador, na medida em que serve de contraponto à livre iniciativa. ${ }^{157}$

O poder diretivo, como expressão da livre iniciativa, sempre deverá ser exercido tendo como premissa a valorização do trabalho e, consequentemente, do trabalhador. E essa valorização se dá através do respeito aos direitos fundamentais e sociais do

\footnotetext{
${ }^{154}$ OLIVEIRA, Paulo Eduardo Vieira de. Aula proferida na disciplina "Direitos da Personalidade e Direito do Trabalho" na Pós Graduação da Faculdade de Direito da Universidade de São Paulo, São Paulo, 20 set. 2010.

${ }^{155}$ MAGANO, Octavio Bueno. Do poder diretivo da empresa, cit., p. 229.

${ }^{156}$ Existem duas referências na Constituição a respeito do valor social do trabalho: a primeira no artigo $1^{\circ}$, inciso IV, que o estabelece como fundamento da República; a segunda no caput do artigo 170, que o indica como um dos princípios da ordem econômica.

${ }^{157}$ REZENDE, Roberto Vieira de Almeida. op. cit., p. 133.
} 
empregado, que são garantias destinadas a promover a concretização da dignidade de pessoa humana.

Os limites internos são aqueles inerentes à própria relação estabelecida entre empregado e empregador e estão representados pelo contrato de trabalho, pelo regulamento interno da empresa e pelos limites criados por órgãos de representação dos trabalhadores dentro da empresa (CIPA, comissão de fábrica, etc.).

O estado de subordinação a que se submete o empregado decorre apenas e tão somente do contrato de trabalho celebrado com o empregador, não competindo a este determinar ordens, fiscalizar ou punir o empregado por atitudes adotadas fora do âmbito contratual. Assim, o que está fora dos limites de execução do próprio contrato de trabalho não interessa ao empregador.

Para Luísa Riva Sanseverino, o poder diretivo deve relacionar-se à prestação do trabalho e a toda circunstância ligada diretamente a ele. As atividades estranhas ao trabalho escapam à relação de subordinação e, consequentemente, não são alcançadas pelo poder de direção do empregador. ${ }^{158}$

Octavio Bueno Magano acrescenta outro limite interno, que é o próprio exercício do poder diretivo. Partindo da premissa que o poder diretivo é um direito-função, o autor sustenta que o sentido da atuação do poder diretivo deve ser a satisfação do interesse não do empregador e sim da empresa, considerada como centro de convergência de múltiplos interesses, tendo em vista também o interesse da comunidade de empregados. ${ }^{159}$

Adicionalmente aos limites destacados pelos doutrinadores acima, apontamos os princípios da razoabilidade e da proporcionalidade como limitadores do poder de direção, em especial no que diz respeito ao poder de controle e punição.

Apesar do seu conceito genérico, a razoabilidade atua como limite a certas faculdades que, caso exercidas de forma abusiva, poderão ser consideradas arbitrárias. Por ser genérica, a razoabilidade deixa ao empregador uma margem de discricionariedade, não possibilitando a arbitrariedade, impedindo que certos direitos, como o da intimidade do trabalhador, sejam violados. ${ }^{160}$ A proporcionalidade, por sua vez, garantirá que os atos praticados pelo empregador para controle e disciplina não serão desproporcionais às situações a que se pretende atingir. Essa concepção é mais visível quando tratamos de

\footnotetext{
${ }^{158}$ SANSEVERINO, Luisa Riva. op. cit., p. 209.

${ }^{159}$ MAGANO, Octavio Bueno. Do poder diretivo da empresa, cit., p. 30 e 229.

${ }^{160}$ OLIVEIRA, Paulo Eduardo Vieira. O dano pessoal no direito do trabalho, cit., p. 153.
} 
punição, visto que a aplicação da pena nunca poderá ser superior à gravidade da falta grave praticada.

Por fim, o poder diretivo é limitado pelas obrigações impostas ao empregador, seja por leis ou princípios, em especial o dever de proteção, de lealdade e de informação.

O dever de proteção obriga o empregador a estabelecer condutas para a proteção física e moral de seus empregados, visto que é sua responsabilidade zelar pela integridade do trabalhador enquanto ele estiver sob as suas ordens. O empregador é responsável por garantir um meio ambiente do trabalho adequado e seguro, sendo este um dos mais importantes e fundamentais direitos do cidadão trabalhador. ${ }^{161}$

Do dever de lealdade decorre o dever de agir com boa-fé. A boa-fé, como obrigação decorrente do contrato de trabalho, igualmente atua como limitadora do exercício do poder diretivo, até porque a execução contratual de boa-fé é um princípio que se extrai da redação do artigo 422 do Código Civil. ${ }^{162}$

O princípio da boa-fé tem um sentido muito especial na execução do contrato de trabalho, em razão do componente pessoal existente neste negócio jurídico. Isso porque o contrato de trabalho não gera direitos e obrigações de cunho exclusivamente patrimonial, criando, também, vínculos pessoais. O contrato de trabalho entre as partes estabelece uma relação estável e continuada que exige confiança recíproca em múltiplos planos, implicando a convicção de que o negócio jurídico estabelecido será cumprido normalmente, sem trapaças, abusos ou desvirtuamentos. Assim, tanto empregador quanto empregado tem obrigação de agir de boa-fé, concedendo à parte contrária a confiança necessária para a execução das respectivas obrigações. ${ }^{163}$

Ainda sobre a boa-fé, Julio Manuel Vieira Gomes entende que desta obrigação decorre o dever de as partes respeitarem a personalidade e a individualidade da contraparte. $^{164}$

Assim, seja pela ótica contratual (na qual os contratos devem ser executados de boa-fé), seja em razão do caráter pessoal que se estabelece na relação de emprego, a boa-fé é essencial para o estabelecimento da relação de emprego, atuando como um limitador importante contra abusos de ambas as partes.

\footnotetext{
${ }^{161}$ MELO, Raimundo Simão de. op. cit., p. 32.

${ }^{162}$ Art. 422. Os contratantes são obrigados a guardar, assim na conclusão do contrato, como em sua execução, os princípios de probidade e boa-fé.

${ }^{163}$ OLIVEIRA, Paulo Eduardo Vieira. $O$ dano pessoal no direito do trabalho, cit., p. 88-89.

${ }^{164}$ GOMES, Júlio Manuel Vieira. op. cit., v. 1, p. 265-266.
} 
No que diz respeito ao dever de informação, temos que o empregado tem o direito de ser informado sobre as condições de trabalho, sendo o empregador obrigado a prestar todos os esclarecimentos sobre os aspectos envolvidos na relação de emprego, incluindo os direitos do trabalhador e os riscos existentes na atividade ou no meio ambiente. Além disso, o poder de organização, de controle e disciplinar sempre deve ser exercido pelo empregador com lisura, ética e transparência, não podendo o empregado ser surpreendido com atos patronais não comunicados.

Caso o empregador não respeite qualquer um dos limites impostos ao seu poder diretivo, haverá abuso do exercício do poder de direção, sendo ao empregado garantida a devida tutela para impedir ou parar esse abuso ou, nas hipóteses em que este já restou configurado, a indenização pelos prejuízos que lhe foram causados. ${ }^{165}$ Adicionalmente, o trabalhador tem o justo direito de resistir à ordem, ao controle que lhe recaiu ou à penalidade que lhe for imposta. Trata-se do direito de resistência, ou jus resistentiae, cuja prática é autorizada pelo exercício irregular do poder diretivo do empregador.

O direito de resistência, como a própria expressão denota, representa o direito do empregado de se recusar a cumprir ordens ilícitas ou abusivas emanadas pelo empregador. Márcio Túlio Viana concebe o jus resistentiae como uma garantia fundamental do trabalhador, acrescentando ser uma das garantias mais importantes pois necessária para evitar a submissão do trabalhador, sinônimo de dignidade perdida. ${ }^{166}$

Sobre o direito de resistência, Alice Monteiro de Barros pondera que

não estão os empregados obrigados a acatar ordens sobre aspectos alheios à relação de emprego e sem qualquer repercussão sobre ela. Isso porque, em regra, a vida privada do empregado, seus costumes, amizades, idéias, orientação sexual e opiniões estão fora do campo da incidência do poder diretivo do empregador, como também suas crenças religiosas, convicções políticas, liberdade sindical, o que se deduz do art. $5^{\circ}$, inciso X, da Constituição de 1988, quando considera invioláveis a intimidade e a vida privada das pessoas, como também os incisos IV, VI, VIII, XVII do mesmo diploma, que garantem a liberdade de pensamento, de crença religiosa, de convicção filosófica ou política e de associação para fins lícitos. Nessas situações, justifica-se a desobediência extralaboral. ${ }^{167}$

\footnotetext{
${ }^{165}$ Sobre os instrumentos contra o abuso de direito do empregador e a tutela da privacidade, o tema será melhor desenvolvido no capítulo 5 do presente trabalho.

${ }^{166}$ VIANA, Márcio Túlio. Direito de resistência, São Paulo: LTr, 1996. p. 70.

${ }^{167}$ BARROS, Alice Monteiro de. Curso de direito do trabalho, cit., p. 55.
} 
Ao recusar o cumprimento de ordens abusivas ou ilícitas, o empregado está exercitando regularmente um direito seu, razão pela qual a negativa do cumprimento à ordem patronal não caracteriza falta grave.

O artigo 483 da Consolidação das Leis do Trabalho prevê a possibilidade de reconhecimento da rescisão indireta do contrato de trabalho se forem constatados abusos no exercício do poder diretivo do empregador. Por sua vez, o artigo 659, IX da norma celetista autoriza o empregado a ajuizar ação específica para impedir a sua transferência abusiva e o inciso $\mathrm{X}$ do mesmo artigo faculta a propositura de ação, com possibilidade de medida liminar, visando "reintegrar no emprego dirigente sindical afastado, suspenso ou dispensado pelo empregador".

Entretanto, apesar da faculdade de resistência oferecida ao empregador e os dispositivos legais que lhe possibilitam o direito de ação judicial para resistência, tem-se que esse direito não é exercido de forma plena pelos trabalhadores. Conforme bem pondera Márcio Túlio Vianna, “o acesso à Justiça para o trabalhador brasileiro, só existe quando ele já deixou o emprego. E mesmo a opção da 'despedida indireta' é uma faca de dois gumes, pois as indenizações raramente cobrem a entressafra da desocupação". ${ }^{168}$

Analisaremos melhor as medidas as serem adotadas individualmente e coletivamente para impedir ou remediar o exercício abusivo do poder diretivo do empregador de forma a afrontar a privacidade do empregado no capítulo 5 do presente estudo.

$\overline{{ }^{168} \text { VIANA, Márcio Túlio. op. cit., p. } 74 .}$ 


\section{O ESTABELECIMENTO DE UM CONCEITO GERAL PARA GARANTIR A PRIVACIDADE DO TRABALHADOR DE ACORDO COM A DINÂMICA DO CONTRATO DE TRABALHO}

\subsection{O empregado e o direito à privacidade}

Após o estabelecimento dos conceitos e aspectos que envolvem a privacidade e o poder diretivo, estamos aptos para estabelecer um conceito geral para garantir o exercício deste direito da personalidade na dinâmica da relação de emprego.

Os direitos da personalidade, como a própria expressão traduz, são inerentes à pessoa e acompanham o indivíduo em todas as suas relações. Enquanto cidadão, o empregado é detentor de direitos fundamentais, dentre os quais, para a finalidade do presente trabalho, se destaca a garantia da sua privacidade, pois esta não é deixada de lado em razão de o trabalhador estar inserido dentro da dinâmica empresarial.

Portanto, a privacidade do indivíduo merece ser respeitada independentemente das situações nas quais ele se encontra. Na relação de emprego, ainda que se faça presente o poder diretivo do empregador, o empregado preserva todos os seus direitos de personalidade.

Também não é demais destacar que conforme exposto no capítulo 2 do presente estudo, o objeto do contrato não é a pessoa do trabalhador, mas sim a sua atividade. Por não ser possível dissociar o trabalho da pessoa que o presta, o empregado reúne a dupla qualidade de titular de direitos fundamentais, sendo que os primeiros the assistem como cidadão, e os segundos são aplicáveis estritamente à relação de emprego. Ao se inserir na organização empresarial, apesar de o trabalhador adquirir direitos decorrentes dessa nova posição jurídica, não perde os seus direitos como cidadão, de que era titular anteriormente como pessoa. ${ }^{169}$

Sobre a cidadania do empregado, Amadeu Guerra destaca a decisão proferida pelo Tribunal Constitucional Espanhol onde restou decidido que

\footnotetext{
${ }^{169}$ ROMITA, Arion Sayão. Direitos fundamentais nas relações de trabalho, cit., p. 187-188.
} 
a celebração de um contrato de trabalho, não implica, de modo algum a privação para uma das partes, o trabalhador, dos direitos que a Constituição lhe reconhece como cidadão, pois nem as organizações empresariais estão inseridas em mundos separados e estanques do resto da sociedade, nem a liberdade de empresa prevista no artigo $38^{\circ}$ do texto constitucional legitima que aqueles que prestam serviços naquelas, por conta e na dependência dos seus titulares, devam suportar esbulhos transitórios ou limitações injustificadas dos seus direitos fundamentais. ${ }^{170}$

A regra geral, portanto, é de respeito total da privacidade do empregado pelo empregador. Sobre esse dever, Sandra Lia Simón reforça que "de nada adiantaria o Estado respeitar o direito à intimidade e à vida privada dos indivíduos, se não houvesse mecanismos que impusessem esse mesmo dever aos empresários, no âmbito das relações laborais". 171

Pensar de forma contrária representaria a negação da individualidade e, principalmente, de dignidade do trabalhador, tornando-o um mero objeto para a realização da finalidade empresarial, ou seja, mais uma ferramenta de produção à disposição do empregador. Nesse sentido, Ingo Wolfgang Sarlet, ao relembrar as palavras de Dworkin, reputa qualquer atitude capaz de reduzir o ser humano à condição de objeto, "como mero instrumento para realização de fins alheios", de forma a negar a importância distintiva de suas próprias vidas. ${ }^{172}$

No âmbito público internacional, apesar de a Organização Internacional do Trabalho não ter editado qualquer Convenção ou Recomendação específica sobre a tutela geral de privacidade do trabalhador, temos que o artigo 4.1 da Convenção 155 da OIT (ratificada pelo Brasil pelo Decreto Legislativo n. 2, de 1992), ${ }^{173}$ que dispõe sobre segurança e saúde do trabalhador e do meio ambiente do trabalho, impõe que os países signatários deverão adotar práticas para garantir a segurança e saúde dos trabalhadores e o meio ambiente de trabalho. Por esse raciocínio, visando à manutenção de um ambiente de trabalho sadio, está vedado ao empregador adotar práticas que afrontem a privacidade do trabalhador. Ainda, a recente Recomendação 200 da Organização Internacional do Trabalho $^{174}$ - que trata sobre a infecção do HIV no mundo do trabalho adotada pela $99^{a}$

\footnotetext{
${ }^{170}$ GUERRA, Amadeu. op. cit., p.48.

${ }^{171}$ SIMÓN, Sandra Lia. op. cit., p. 102

${ }^{172}$ SARLET, Ingo Wolfgang. op. cit., p. 59.

${ }^{173} \mathrm{O}$ texto integral da Convenção 155 foi obtido através do site: INSTITUTO AMP. Disponível em: $<$ http://www.institutoamp.com.br/oit155.htm>. Acesso em: 16 dez. 2010.

${ }^{174} \mathrm{O}$ inteiro teor da Recomendação 200 da OIT foi obtido em: INTERNATIONAL LABOUR ORGANIZATION. Conferência Internacional do Trabalho. Recomendação 200. Recomendação sobre a
} 
Seção da Conferência Internacional do Trabalho, em 17 de junho de 2010 - estabelece diversas regras que visam preservar a privacidade do portador do HIV, bem como os seus familiares.

No domínio europeu, a Carta dos Direitos Fundamentais da União Europeia estabelece princípios gerais de respeito à vida privada no seu artigo $7^{\circ}$ e de proteção de dados pessoais no artigo $8^{\circ}$. A Diretiva 95/46/CE, que trata da proteção de dados pessoais; e a Diretiva 2006/24/CE, que trata da conservação de dados gerados ou tratados na oferta de serviços de comunicações eletrônicas públicas ${ }^{175}$ tiveram reflexo (em maior ou menor escala) nas disposições legais trabalhistas dos Estados-membros.

O Estatuto de los Trabajadores da Espanha prevê expressamente em seu artigo $4^{\circ}$ que os empregados têm direito ao respeito de sua intimidade e dignidade no ambiente de trabalho, compreendendo a proteção frente a ofensas verbais, físicas ou de natureza sexual. ${ }^{176} \mathrm{O}$ artigo 20 do mesmo dispositivo legal, apesar de facultar ao empregador a adoção de quaisquer medidas que considere adequadas para verificar o cumprimento das atividades profissionais, limita o exercício desta fiscalização ao respeito e preservação da dignidade humana do trabalhador.

A legislação trabalhista francesa também possui uma cláusula geral de tutela da privacidade no ambiente de trabalho. O artigo L1121-1 do Código do Trabalho francês, ao vedar de forma ampla a afronta aos direitos humanos e as liberdades individuais dentro da relação de emprego, pode ser considerado como a base legal, em matéria de direito do trabalho, para a proteção da privacidade do empregado.

Luísa Riva Sanseverino, ao analisar a tutela da pessoa e da personalidade do trabalhador, salienta que a legislação italiana prevê expressamente a proteção da integridade física e personalidade moral do empregado na relação de emprego, traduzindose em uma série de comportamentos obrigatórios, os quais integram a chamada posição contratual do empregado em face dos seus dependentes. ${ }^{177}$

infecção VIH e SIDA e o mundo do trabalho, adoptada pela Conferência Internacional do Trabalho na sua nonagésima nona sessão, em Genebra, a 17 de junho de 2010. Disponível em: <http://www.ilo.org/public/portugue/region/eurpro/lisbon/pdf/recomendacao_200.pdf> Acesso em: 05 dez. 2010.

${ }^{175} \mathrm{O}$ inteiro teor das disposições da União Europeia foram obtidas através do site: EUR-Lex: acesso ao direito da União Europeia. Disponível em: <http://eur-lex.europa.eu/pt/index.htm>. Acesso em 05 dez. 2010.

${ }^{176}$ Art. $4^{\circ}, 2$, e. En la relación de trabajo los trabajadores tienen derecho (...) al respeto de su intimidad y la consideración debida a su dignidad, comprendida la protección frente a ofensas verbales o físicas de naturaleza sexual.

${ }^{177}$ SANSEVERINO, Luisa Riva. op. cit., p. 260. 
A legislação portuguesa foi pioneira a prever de forma detalhada no Código do Trabalho a concretização de direitos de personalidade no âmbito das relações laborais, tendo incorporado diversos dispositivos das Diretivas da União Europeia citadas acima, especialmente a 95/46/CE.

O reconhecimento legislativo dos direitos de personalidade no âmbito da relação de trabalho representou um progresso qualitativo na concepção da relação de emprego ao reconhecer expressamente a cidadania no ambiente de trabalho, princípio que invoca a qualidade de vida pessoal e profissional do empregado ${ }^{178}$.

A normatização ampla sobre os direitos da personalidade no Código do Trabalho de Portugal expressa a constitucionalização da relação laboral e a noção de que não há separação entre a figura do trabalhador subordinado e do cidadão. ${ }^{179}$

Ao prever expressamente sobre os direitos de personalidade no Código do Trabalho, o legislador português buscou esclarecer dúvidas sobre a concretização desses direitos para empregado e empregador, pois antes da existência de regras expressas para o âmbito do trabalho, a utilização das normas constitucionais e civis suscitava dúvidas quanto a sua aplicação prática na relação de emprego, em especial quanto à limitação do empregador de fiscalizar a prestação de serviços do empregado com câmeras de vídeo, exigir exames médicos ou controlar as comunicações efetuadas pelo empregado, principalmente o correio eletrônico. ${ }^{180}$

O Código do Trabalho português possui uma cláusula geral de tutela da reserva da intimidade da vida privada, que está prevista no seu artigo $16^{\circ}$ do Código do Trabalho ${ }^{181}$, sendo este considerado, também, como um dispositivo de tutela geral dos direitos de personalidade na relação de trabalho.

A reserva da intimidade da vida privada disposta na segunda parte do artigo $16^{\circ}$ do Código do Trabalho impede não só o acesso às informações atinentes à esfera íntima e

\footnotetext{
${ }^{178}$ REDINHA, Maria Regina. Os direitos de personalidade no Código do Trabalho: actualidade e oportunidade da sua inclusão, p. 2.

${ }^{179}$ GOMES, Júlio Manuel Vieira. op. cit., v. 1, p 265.

${ }^{180}$ MARTINEZ, Pedro Romano. Direito do trabalho. 3. ed. Coimbra: Almedina, 2006. p. 350.

${ }^{181}$ Reserva da intimidade da vida privada:

1 - O empregador e o trabalhador devem respeitar os direitos de personalidade da contraparte, cabendolhes, designadamente, guardar reserva quanto à intimidade da vida privada;

2 - $\mathrm{O}$ direito à reserva da intimidade da vida privada abrange quer o acesso, quer a divulgação de aspectos atinentes à esfera íntima e pessoal das partes, nomeadamente relacionados com a vida familiar, afectiva e sexual, com o estado de saúde e com as convicções políticas e religiosas.
} 
pessoal das partes, como também impede as divulgações dessas informações que tenham sido informadas por vontade própria pela outra parte.

A ingerência do empregador sobre os aspectos da vida íntima do trabalhador que não tenham relação com as atividades desenvolvidas em decorrência do contrato de trabalho também é vedada pelo artigo $16^{\circ}$ do Código do Trabalho. As condutas do trabalhador fora do ambiente de trabalho não importam para a execução das atividades laborais e, portanto, não podem servir como motivo para a modificação ou cessação do contrato de trabalho.

Em certos casos, entretanto, se os aspectos que envolvem a esfera privada do trabalhador podem colocar em jogo o bom nome, a imagem, ou a honra do empregador (direitos de personalidade também garantidos), ou, ainda, podem prejudicar terceiros envolvidos com a relação de trabalho, a doutrina portuguesa, excepcionalmente, tem entendido ser possível a ingerência do empregador sobre esses aspectos personalíssimos. Se a relação de confiança for abalada por atos ou se o comportamento do empregado tornar impraticável a manutenção do contrato, em casos especialíssimos, a doutrina portuguesa entende ser possível a dispensa com justa causa. ${ }^{182}$

O próprio Código do Trabalho português, apesar de seguir a regra geral para a tutela da privacidade no ambiente de trabalho, admite exceções a essa regra, possibilitando, em alguns casos muito específicos, a limitação da privacidade, desde que observadas algumas regras definidas pelo legislador.

No âmbito do direito do trabalho brasileiro, a Consolidação das Leis do Trabalho não se detém na disciplina da preservação dos direitos da personalidade ou na tutela da privacidade na relação de emprego, limitando-se a casos específicos, como fez no artigo 482, alínea "j” e artigo 483, alínea "e" - onde prevê como hipótese de justa causa para a rescisão do trabalho, tanto por parte do empregado como do empregador, a ofensa à honra e à boa fama -, ou no artigo 373-A - onde proíbe a revista íntima em empregadas mulheres.

Apesar de a legislação trabalhista proibir revistas íntimas, e dispor sobre a possibilidade de justa causa por ofensa à honra, a lei é silente quanto aos demais direitos da personalidade relacionados à integridade moral do trabalhador, não demonstrando qualquer

\footnotetext{
${ }^{182}$ MARTINEZ, Pedro Romano. op. cit., p. 97.
} 
preocupação com questões que atualmente afligem o direito estrangeiro, como o tratamento de dados e controle dos meios de comunicação no trabalho.

Estevão Mallet entende que a omissão da Consolidação das Leis do Trabalho na disciplina dos direitos da personalidade do empregado "decorre da visão reducionista do legislador, que tratou da relação de emprego como se nela as obrigações das partes se restringissem à prestação do trabalho pelo empregado, de um lado, e ao pagamento da remuneração pelo empregador, de outro lado" acarretando uma visão meramente patrimonial da relação de emprego. ${ }^{183}$

No entanto, não concordamos com tal afirmação, uma vez que a Consolidação das Leis do Trabalho não se preocupa apenas com o caráter patrimonial da relação de emprego, sendo que existem vários dispositivos legais que cuidam da preservação da saúde, higiene, medicina e segurança do trabalhador. Na realidade, entendemos que a escassa previsão celetista em matéria de direitos da personalidade relacionados à integridade moral decorre do fato de a discussão da concretização destes direitos na relação de emprego ser fenômeno relativamente novo. De fato, à época da aprovação da Consolidação das Leis do Trabalho, a concepção de meio ambiente do trabalho seguro e sadio estava limitada ao espaço físico e ao modo como o serviço era prestado pelo trabalhador. O reconhecimento do pleno exercício da privacidade como um direito necessário para um ambiente de trabalho sadio é recente; tanto isso é verdade que o dispositivo que proíbe a revista íntima (artigo 373-A CLT) foi incluído pela Lei $n^{\circ} 9.799$, de 26.5.1999, ou seja, 56 anos após a aprovação da CLT.

A ausência de previsões específicas na Consolidação das Leis do Trabalho para a concretização dos direitos da personalidade e, em especial, da privacidade no ambiente de trabalho, não afasta a garantia deste direito ao empregado ${ }^{184}$, tendo em vista que a ele aplica-se, subsidiariamente, a previsão do direito comum, bem como as normas e princípios constitucionais, pilares do nosso ordenamento jurídico, em especial, o artigo $5^{\circ}$, inciso X da Constituição Federal. ${ }^{185}$

\footnotetext{
${ }^{183}$ MALLET, Estêvão. Direitos de personalidade e direito do trabalho. Revista do Advogado, São Paulo, v. 24, n. 76, p. 13, jun. 2004.

${ }^{184} \mathrm{E}$, até mesmo, ao empregador, visto que existem situações passíveis de ofensa da privacidade patronal, especialmente na relação de trabalho doméstico.

${ }^{185}$ Para Sandra Lia Simón, a ausência de tutela específica, obrigando a incidência da previsão genérica constitucional "é a principal virtude do ordenamento jurídico brasileiro, pois possibilita que todas as situações que envolvam esses bens da personalidade se adaptem à previsão normativa, sem sofrer eventual engessamento provocado pelo legislador infraconstitucional, como ocorre, por exemplo, na Espanha". (SIMÓN, Sandra Lia. op. cit., p. 127).
} 
Afastar a tutela da privacidade do trabalhador por ausência de previsão legal representaria uma afronta à própria Constituição, visto que o empregado, enquanto cidadão, é detentor de direitos da personalidade.

O simples fato de o empregado estar subordinado e receber salário do seu empregador não autorizam este último, em nome de um "suposto poder de direção", a desrespeitar a privacidade do trabalhador. ${ }^{186}$

Além da garantia constitucional conferida ao empregado cidadão, o contrato de trabalho apresenta, ainda que implicitamente, o direito e a obrigação ao respeito aos direitos personalíssimos. Caso contrário, a Consolidação das Leis do Trabalho não elencaria nos seus artigos 482 e 483 a possibilidade de rescisão do contrato de trabalho quando da ocorrência de atos lesivos à honra e à boa fama. Ainda, a identificação da proteção jurídica da dignidade do empregado é constatada em múltiplas restrições ao exercício da autonomia contratual do empregador, incidindo e integrando o contrato de trabalho. $^{187}$

Considerando que os negócios jurídicos entre particulares estão sujeitos à observância das normas constitucionais que garantem os direitos fundamentais, o contrato de trabalho deve obedecer aos direitos fundamentais previstos na Constituição. Restam, portanto, afastadas as interpretações tendentes a reconhecer que o estado de subordinação jurídica do empregado, decorrente do contrato individual de trabalho, representa renúncia aos seus direitos fundamentais. Pensar ao contrário implicaria admitir que a subordinação jurídica traria como efeito a mitigação da própria condição humana do empregado, transformando-o apenas em mais uma peça da engrenagem do sistema produtivo. Este raciocínio, por seu turno, se chocaria de plano com o entendimento unanimamente consagrado na doutrina dos direitos fundamentais de sua inerência absoluta ao ser humano. ${ }^{188}$

No contexto do contrato de trabalho podemos afirmar que a tutela da privacidade é imprescindível, posto que na relação de emprego os direitos da personalidade relacionados à integridade moral estão mais suscetíveis de violação.

\footnotetext{
${ }^{186}$ OLIVEIRA, Paulo Eduardo Vieira de. A privacidade da pessoa humana no ambiente de trabalho. Revista do Departamento de Direito do Trabalho e da Seguridade Social da Faculdade de Direito da USP, São Paulo, v. 1, n. 1, p. 164, jan./jun. 2006.

${ }^{187}$ Id. O dano pessoal no direito do trabalho, cit., p. 87.

${ }^{188}$ REZENDE, Roberto Vieira de Almeida. op. cit., p. 59.
} 
Assim, com o regramento constitucional e legislativo genérico, de onde é possível extrair uma tutela geral de privacidade, bem como mediante a aplicação dos dispositivos de direito público internacional, é possível tutelar, nos dias de hoje, o direito à privacidade do empregado no Brasil, sem a necessidade de regras legais específicas.

\subsection{Direito de propriedade, poder de direção e privacidade do empregado}

A simples proteção do patrimônio do empregador, apesar de direito fundamental também garantido constitucionalmente no artigo $5^{\circ}$ da Constituição, por ser uma garantia meramente patrimonial, não tem o condão de afastar totalmente a garantia da privacidade do trabalhador.

Do confronto entre um direito fundamental de cunho meramente patrimonial (propriedade) contra um direito nato, inerente à condição e existência do indivíduo (privacidade), não há como sustentar a prevalência do primeiro, sob pena de afronta à dignidade da pessoa humana.

Não há dúvida que a ponderação destes dois direitos fundamentais, apesar de hierarquicamente dispostos no mesmo patamar legal (artigo $5^{\circ}$ da Constituição), não poderá ser realizada em detrimento da garantia que nos parece ter maior relevância para a própria condição humana, ou seja, o direito da personalidade.

A propriedade se adquire e se aliena, não sendo garantida a todos os cidadãos, uma vez que a grande parcela da população brasileira sequer a possui. A personalidade, por sua vez, é condição inerente ao ser humano, do qual não pode se dissociar, sendo uma demonstração da sua dignidade.

Desta forma, o exercício do poder diretivo como uma simples manifestação do direito de propriedade do empregador não é suficiente para afastar a garantia constitucional à privacidade, pois, embora integrante do rol de direitos fundamentais, a propriedade privada não se sobrepõe ao livre exercício da personalidade, que é um instrumento imprescindível para a vida digna, um dos fundamentos da República.

No que diz respeito ao direito de propriedade do empregador sobre os equipamentos - que são ferramentas de trabalho colocadas à disposição para a execução do serviço -, tal argumento também não pode ser utilizado para justificar a invasão da 
privacidade do trabalhador. Isso porque, o fato de a ferramenta ter sido alcançada para a utilização no ambiente de trabalho, não retira o direito do empregado de um mínimo de privacidade no uso de tal instrumento. Entender de outra forma seria legitimar a atitude do empregador que arromba e vasculha a gaveta que o empregado mantém trancada em sua mesa de trabalho com os seus pertences pessoais, sob o simples argumento de que a gaveta e a mesa são de propriedade da empresa.

Nesse sentido, concordamos com a posição de Roberto Vieira de Almeida Rezende, que sustenta a necessidade de se estabelecer uma nova concepção da proporcionalidade entre direito de propriedade do empregador e direitos fundamentais do empregado, criticando a atual tendência da jurisprudência ao colocar os dois direitos no mesmo patamar, possibilitando a violação da privacidade obreira em razão da garantia do direito patrimonial. Para o autor, embora o direito de propriedade deva ser respeitado por fazer parte do rol de direitos e garantias individuais constitucionais e por ser princípio da ordem econômica, não pode justificar invasões excessivas nos direitos fundamentais do trabalhador. E justifica:

\begin{abstract}
a propriedade figura tão-somente como direito fundamental por uma equiparação legal, resultante do acolhimento de concepções liberais da sociedade e da ordem econômica, tendo em vista que, em sua gênese, não consiste em direito genuinamente humano como os demais direitos fundamentais. Portanto, este dado há que ser considerado no momento em que se realizada a aplicação do critério da proporcionalidade entre a propriedade e os demais direitos fundamentais ${ }^{189}$.
\end{abstract}

Resta afastado, portanto, o simples exercício do direito de propriedade como justificativa para a negação do direito à privacidade do trabalhador.

\title{
3.3. Limitação à privacidade
}

Apesar de reconhecermos a existência de uma tutela geral de privacidade do trabalhador, os argumentos apresentados até agora não representam a defesa da tese de que o empregado possui direito ilimitado e irrestrito à privacidade no ambiente de trabalho, até porque, conforme já sustentado no capítulo 1 do presente trabalho, é possível admitir a limitação dos direitos da personalidade em situações específicas e autorizadas por lei. A

\footnotetext{
${ }^{189}$ REZENDE, Roberto Vieira de Almeida. op. cit., p. 208-209.
} 
defesa da concretização da privacidade no ambiente de trabalho não desconsidera a existência de situações que podem levar à limitação do exercício desse direito, conforme se verá a seguir.

O primeiro aspecto a ser considerado diz respeito ao fato de não se poder conferir ao trabalhador, no ambiente de trabalho, o mesmo nível de liberdade que ele possui em sua residência ou em suas relações pessoais. Não há como negar que o empregado, por estar inserido na estrutura empresarial, tendo a sua atividade subordinada ao empregador por força do contrato de trabalho, não está livre para fazer o que tiver vontade. Por exemplo, se na sua residência o empregado é livre para usar (ou não) as vestimentas de acordo com a sua vontade, na empresa essa liberdade não existe, pois há, no mínimo, uma obrigação implícita para a utilização de roupas condizentes com o ambiente de trabalho.

A segunda consideração a ser realizada diz respeito ao fato de que o empregado, ao colocar a sua força de trabalho à disposição do empregador, também perde parte de sua autonomia, visto não poder se negar a cumprir determinações empresariais emanadas dentro dos limites legais. A relação contratual implica, por si só, em uma forma de autorrestrição do direito pelas partes. No contrato de trabalho, em razão da sua característica de adesão, esta restrição fica mais evidente.

Confirmando essa linha de raciocínio, Roberto Vieira de Almeida Rezende pondera que, apesar de o contrato de trabalho sempre ter que ser considerado sob a perspectiva da hipossuficiência do trabalhador, não há como negar que, ao firmá-lo, o trabalhador pratica um ato de autorrestrição, colocando à disposição do empregador não apenas a sua força de trabalho, como também parte de sua liberdade e autonomia de ação. E, conclui que se assim não fosse, não haveria sequer como se cogitar da figura do contrato. ${ }^{190}$

O terceiro ponto a ser destacado consiste no inegável fato de que o exercício dos direitos fundamentais do trabalhador encontra naturais limitações decorrentes da coexistência e eventual confronto destes com os direitos fundamentais de terceiros em geral, dos colegas e, dependendo da situação, do próprio empregador. ${ }^{191}$ Além do respeito às ordens emanadas do exercício do poder diretivo do empresário, o trabalhador deve também respeitar a liberdade dos seus colegas de trabalho, havendo, portanto, natural limitação a este direito fundamental.

\footnotetext{
${ }^{190}$ REZENDE, Roberto Vieira de Almeida. op. cit., p. 191.

${ }^{191}$ GOMES, Júlio Manuel Vieira. op. cit., v. 1, p. 265-266.
} 
No que diz respeito à garantia do exercício dos direitos fundamentais do empregador, colegas de trabalho e terceiros, é importante destacar que existem situações em que a privacidade do trabalhador e direitos de igual ou maior posição hierárquica em nosso ordenamento constitucional se opõem e se contrapõem. Como exemplo, citamos o direito à vida, à saúde, que apesar de serem direitos personalíssimos, possuem maior valor para a própria existência do homem. Nessas situações, seria impossível admitir a prevalência absoluta da privacidade do trabalhador em detrimento do direito à vida ou à segurança de todas as demais pessoas que se relacionam com o trabalhador em razão da execução do contrato de trabalho.

Como desdobramento do exposto acima, é possível também constatar situações em que, em razão da natureza da atividade desenvolvida pelo trabalhador, há obrigação legal para a limitação da sua privacidade. Como exemplo, citamos a Lei n. 7.102, de 1983, que dispõe sobre segurança para estabelecimentos financeiros e funcionamento das empresas particulares que exploram serviços de vigilância e transporte de valores. Por esta norma, o estabelecimento financeiro é obrigado a adotar sistema de vigilância ostensiva e eletrônica para a filmagem do local de trabalho. Os trabalhadores destas instituições, portanto, não podem deixar de se submeter a esse tipo de vigilância. Ainda fazendo referência a esta mesma lei, citamos a situação do vigilante, que para o exercício da profissão deve, obrigatoriamente, se submeter a exame mental e psicotécnico (além do exame físico) e apresentar certidão de antecedentes criminais sem registros anteriores.

Diante das situações acima destacadas, por mais que se busque garantir a tutela geral da privacidade do trabalhador, não há como negar que a sua inserção no ambiente empresarial, a execução do próprio contrato de trabalho e a existência de outros direitos de igual ou maior valor, além das situações propriamente previstas em lei, demandam uma limitação (em maior ou menor grau, dependendo da situação) ao exercício pleno desse direito personalíssimo.

Além do mais, como já exposto no capítulo 1, não há direito que seja imune a qualquer tipo de restrição ou limitação, sendo que a própria Declaração Francesa dos direitos do Homem e do Cidadão, de 1789, já preceituava que "A liberdade consiste em poder fazer tudo quanto não incomode o próximo; assim o exercício dos direitos naturais 
de cada homem não tem limites senão nos que asseguram o gozo destes direitos. Estes limites não podem ser determinados senão pela lei”. ${ }^{192}$ (grifamos)

No ordenamento jurídico nacional, o Artigo 11 do Código Civil ${ }^{193}$ possibilita a limitação voluntária dos direitos da personalidade, desde que esta limitação esteja prevista em lei.

Quanto à necessidade de previsão legal, o primeiro aspecto que deverá ser verificado é se existe dispositivo legal capaz de autorizar a limitação da privacidade do empregado, tendo em vista a condição imposta pelo artigo 11 do Código Civil.

Pois bem, considerando que o poder de direção tem como fundamentos legais os artigos $2^{\circ}, 3^{\circ}$ e 442 da Consolidação das Leis do Trabalho, os quais concedem ao empregador a prerrogativa de dirigir a prestação pessoal do trabalho e estabelecem a subordinação jurídica do empregado; e que o inciso III do artigo 932 do Código Civil atribui inderetamente ao empregador o dever de fiscalizar as atividades de seus empregados ou prepostos, entendemos que estes dispositivos, na esfera ordinária, autorizam a limitação da privacidade. No âmbito constitucional, o inciso IV do artigo $1^{\mathrm{o}} \mathrm{e}$ os incisos XXII e XXIII do artigo $5^{\circ}$ (direito de propriedade), bem como o artigo 170 (livre iniciativa, ordem econômica e direito de propriedade) constituem fundamento para o exercício do poder diretivo e, via de consequência, a limitação da privacidade.

De igual forma, o próprio exercício dos direitos fundamentais de terceiros previstos na Constituição Federal também autoriza, sob o aspecto legal, a limitação desse direito da personalidade relacionado à integridade moral do empregado.

Portanto, com a aplicação dos dispositivos legais existentes entendemos ser possível sustentar a existência de uma base legal para a limitação da privacidade.

Nesse ponto, é importante reforçar que a limitação não representa renúncia ou abdicação total do direito, sendo que o desafio que se coloca é como resguardar e concretizar a privacidade do empregado considerando todos os aspectos envolvidos na relação de emprego e apontados acima. Na limitação, ao contrário do que ocorre na renúncia, mantém-se o núcleo essencial do direito. A preservação do núcleo da privacidade é imprescindível para garantir a dignidade do trabalhador. Ou seja, o

\footnotetext{
${ }^{192}$ DECLARAÇÃO DOS DIREITOS DO HOMEM E DO CIDADÃO. DHnet - Direitos Humanos na Internet. Disponível em: <http://www.dhnet.org.br/direitos/anthist/dec1789.htm>. Acesso em: 22 set. 2010.

${ }^{193}$ Art. 11. Com exceção dos casos previstos em lei, os direitos da personalidade são intransmissíveis e irrenunciáveis, não podendo o seu exercício sofrer limitação voluntária.
} 
empregado não abdicará integralmente do seu direito de personalidade, mas, em razão dos aspectos envolvidos na relação de trabalho, apenas consentirá provisoriamente em não exercer plenamente esse direito.

Não defendemos a limitação em qualquer hipótese ou por qualquer interesse do empregador, tampouco fundamentada no exercício do direito de propriedade patronal. As situações nas quais admitimos a limitação estão adstritas às hipóteses em que a restrição é imprescindível, seja para a execução do próprio contrato de trabalho (em razão das suas peculiaridades técnicas), seja para a garantia de outros direitos fundamentais de igual ou maior relevância que a garantia individual de privacidade.

Concordamos com as ponderações de Teresa Alexandra Coelho Moreira que sustenta que a limitação aos direitos da personalidade do trabalhador deve ser realizada com restrições e só é admitida em certos termos, pois não é pelo fato de o trabalhador "entrar nos muros da empresa" que deixa de poder gozar dos seus direitos enquanto pessoa, enquanto cidadão. ${ }^{194}$

Por fim, entendemos que qualquer ato patronal que visar restringir a privacidade do empregado (ainda que autorizado conforme as ponderações acima) deverá observar todos os princípios e obrigações que limitam o exercício do poder diretivo ${ }^{195}$. Especialmente, a obrigação de proteção, de lealdade (boa-fé) e de informação devem servir como limitadores do empregador na prática de atos autorizados para a restrição da privacidade do trabalhador. De igual forma, os limites externos e internos do exercício do poder diretivo, em especial os direitos fundamentais, devem ser balizadores das práticas adotadas pelo empregador visando limitar a privacidade do trabalhador. Além disso, o poder diretivo não pode ser exercido em descompasso com os ditames da justiça social ${ }^{196}$, significando que a limitação da privacidade do trabalhador deve sempre respeitar as relações de integração inerentes à vida social do ser humano.

Por todo o exposto, temos que a regra geral a ser aplicada à relação de emprego é no sentido de a privacidade do empregado ser irrenunciável. Ou seja, via de regra, o empregado deve ter garantido o exercício deste direito da personalidade. No entanto, em razão da dinâmica do contrato de trabalho e da existência de outros direitos fundamentais de igual ou maior relevância, não há como negar a existência de algumas situações onde é

\footnotetext{
${ }^{194}$ MOREIRA, Teresa Alexandra Coelho. op. cit., p. 123.

${ }^{195}$ Quanto aos limitadores do poder diretivo e do contrato de trabalho, vide capítulo 2.

${ }^{196}$ REZENDE, Roberto Vieira de Almeida. op. cit., p. 140.
} 
possível admitir a limitação da privacidade do trabalhador sem que isso represente uma afronta ao núcleo essencial do direito.

Essa limitação, entretanto, somente está autorizada em situações muito específicas e diante de condições que justifiquem, efetivamente, o ato patronal limitador, conforme argumentos que desenvolveremos a seguir.

\subsection{Situações e condições para a limitação}

Conforme já sustentamos, existem situações na dinâmica laboral em que o pleno exercício do direito da personalidade do trabalhador colide com o exercício de outros direitos fundamentais de titularidade do empresário, dos demais colegas de trabalho ou de terceiros alheios à relação empregatícia, mas que de alguma forma se relacionam com o empregado em razão das suas atividades. No entanto, a limitação da privacidade decorrente da sua colisão com outras garantias fundamentais não pode ser realizada em qualquer situação e sob qualquer pretexto. Impõe-se a efetiva ponderação dos interesses em jogo, considerando a força normativa dos princípios, em especial, o princípio da proporcionalidade.

Quando nos deparamos com uma situação concreta onde há colisão de direitos, deve-se levar em conta o peso relativo de cada um deles a fim de obter a solução do conflito. JJ Gomes Canotilho ensina que "considera-se existir uma colisão autêntica de direitos fundamentais quando o exercício de um direito fundamental por parte de seu titular colide com o exercício do direito fundamental por parte de outro titular". ${ }^{197}$

Diante da verificação de conflito de direitos fundamentais, doutrina e jurisprudência têm se firmado no sentido de resolver esse confronto através da aplicação do princípio da proporcionalidade, que busca a ponderação das garantias constitucionais, dos interesses e bens jurídicos em que se expressam, de forma a permitir o máximo de respeito possível a todos os direitos envolvidos.

Por tal princípio, o intérprete deve buscar conformar os direitos e garantias aparentemente em conflito no discurso constitucional, de sorte que a aplicação de um deles

\footnotetext{
${ }^{197}$ CANOTILHO, Joaquim José Gomes. Direito constitucional e teoria da constituição. 5. ed. Coimbra: Almedina, 1991. p. 1229.
} 
não implique necessariamente a exclusão do outro. Os bens jurídicos protegidos pela Constituição devem ser tomados de forma coordenada. ${ }^{198}$

Para Alexandre de Morais, para a solução do conflito de direitos e bens constitucionalmente protegidos deve-se buscar a compatibilização das normas constitucionais, de forma que todas tenham aplicabilidade. ${ }^{199}$

Neste sentido, a doutrina aponta diversas regras de hermenêutica constitucional para auxiliar a interpretação e solução dos conflitos.

Alexandre de Morais utiliza-se de doutrina para apontar os princípios e as regras interpretativas das normas constitucionais: a) da unidade da constituição: a interpretação constitucional deve ser realizada de maneira a evitar contradições entre suas normas; b) do efeito integrador: na resolução dos problemas jurídico-constitucionais, deverá ser dada maior primazia aos critérios favorecedores da integração política e social, bem como ao reforço da unidade política; c) da máxima efetividade ou eficiência: a uma norma constitucional deve ser atribuído o sentido que maior eficácia lhe conceda; d) da justeza ou da conformidade funcional: os órgãos encarregados da interpretação da norma constitucional não poderão chegar a uma posição que subverta, altere ou perturbe o esquema organizatório-funcional constitucionalmente estabelecido pelo legislador constituinte originário; e) da concordância prática ou da harmonização: exige-se a coordenação e combinação dos bens jurídicos em conflito, de forma a evitar o sacrifício total de uns em relação aos outros; e f) da força normativa da constituição: entre as interpretações possíveis, deve ser adotada aquela que garanta maior eficácia, aplicabilidade e permanência das normas constitucionais. ${ }^{200}$

Ainda, ao apontar as formas de solução de interpretação nos conflitos e colisões de direitos e garantias, Alexandre de Morais, além de socorrer-se das lições de Canotilho, aponta, em complementação, as regras propostas por Jorge Miranda: ${ }^{201}$ a) a contradição dos princípios deve ser superada, ou por meio da redução proporcional do âmbito do alcance de cada um deles, ou, em alguns casos, mediante a preferência ou a prioridade de certos princípios; b) deve ser fixada a premissa de que todas as normas constitucionais desempenham uma função útil no ordenamento, sendo vedada a interpretação que lhe

\footnotetext{
${ }^{198}$ REZENDE, Roberto Vieira de Almeida. op. cit., p. 93.

${ }^{199}$ MORAES, Alexandre de. Direito constitucional, cit., p. 45.

${ }^{200}$ Id. Constituição do Brasil interpretada e legislação constitucional, cit., p. 109.

${ }^{201}$ Id. Direito constitucional, cit., p. 47.
} 
suprima ou diminua a finalidade; c) os preceitos constitucionais deverão ser interpretados tanto explicitamente quanto implicitamente, a fim de colher-se seu verdadeiro significado.

A palavra-chave para a solução do confronto estabelecido e ao modo de aplicação do direito chama-se equilíbrio, ou seja, a proporcionalidade de cada direito. Desta forma, do confronto entre garantias de mesmo nível hierárquico, um não pode se sobrepor ao outro, sendo que estes devem ser harmonizados através da integração das garantias, objetivando a máxima observância e mínima restrição.

De outra parte, do confronto de direitos constitucionais de níveis hierárquicos divergentes, deve-se levar em conta a natureza e a hierarquia do bem jurídico constitucionalmente protegido, bem como o peso da intervenção e a intensidade da ameaça. Quanto maior a posição hierárquica do bem tutelado pela garantia constitucional, maior o dever de proteção e a necessidade de se garantir uma maior efetividade a este no exercício de ponderação.

Para Alexandre de Morais a aplicação das regras de interpretação acima indicadas deverá, em resumo, "buscar a harmonia do texto constitucional com suas finalidades precípuas, adequando-se à realidade e pleiteando a maior aplicabilidade dos direitos, garantias e liberdades públicas". ${ }^{202}$

Nenhum direito pode ser exercido de forma irrestrita quando este exercício representar a afronta ou negação de outro direito de igual ou maior valor. $\mathrm{O}$ direito à privacidade pode sofrer ajuste ou limitação sempre quando existir a necessidade de tutelar outro direito igual ou de maior relevância no caso concreto. Daí a necessidade da interpretação responsável e coerente resguardando ao máximo a privacidade do empregado mesmo na situação onde outros princípios ou garantias constitucionais estão em jogo.

Por consequência, quando estiverem em jogo direitos maiores ou em mesmo grau hierárquico que os direitos fundamentais individuais será possível conceber a limitação da privacidade do empregado, através da aplicação do princípio da proporcionalidade, de forma a garantir a limitação mínima desse direito e a sua efetividade máxima, sem alterar o seu núcleo sensível e essencial.

A concretização dos direitos da personalidade no Código do Trabalho de Portugal confirma os argumentos ora defendidos. A tutela dos direitos personalíssimos na relação de emprego no referido ordenamento jurídico parte da regra geral da proteção máxima,

\footnotetext{
${ }^{202}$ MORAES, Alexandre de. Direito constitucional, cit., p. 47.
} 
aceitando exceções a essa regra apenas nas situações nas quais estão envolvidos outros direitos de igual ou maior valor. Com tal atitude, nota-se a preocupação do legislador português em realizar uma efetiva ponderação de interesses, onde os titulares dos direitos fundamentais devem ceder na medida do necessário para que os direitos envolvidos produzam igualmente o seu efeito, evitando ao máximo o prejuízo para ambas as partes.

Diante das considerações acima, ousamos estabelecer os seguintes critérios objetivos para que seja possível admitir a limitação da privacidade do trabalhador:

\subsubsection{Quando estiverem em jogo outras garantias constitucionais de igual ou maior relevância, especialmente relacionadas a terceiros ou à coletividade}

Não há dúvida sobre a efetividade dos direitos fundamentais do empregado na relação de emprego, pois o estado de subordinação da sua atividade não lhe retira esse direito. Contudo, conforme acima exposto, é possível admitir a limitação destes direitos fundamentais quando houver a necessidade da sua ponderação com outros direitos constitucionalmente reconhecidos, de forma a garantir o exercício de todas as garantias constitucionais em jogo, especialmente de terceiros ou da coletividade.

Segundo Ingo Wolfgang Sarlet

não podemos deixar de lembrar - na esteira de Alexy - que até mesmo o princípio da dignidade da pessoa humana (por força de sua própria condição principiológica) acaba por sujeitar-se, em sendo contraposto à igual dignidade de terceiros, a uma necessária relativização, e isto não obstante se deva admitir - no âmbito de uma hierarquização axiológica sua prevalência no confronto com outros princípios e regras constitucionais, mesmo em matéria de direitos fundamentais. ${ }^{203}$

Ingo Wolfgang Sarlet pondera que apesar de a concepção da dignidade da pessoa humana ter por escopo o indivíduo, não há como negar uma necessária dimensão comunitária ou social desta mesma dignidade, principalmente por serem todos iguais em dignidade e direitos. O autor utiliza-se dos argumentos de Kant para reforçar o caráter intersubjetivo e relacional da dignidade da pessoa humana. ${ }^{204}$ Esse raciocínio poderia nos

\footnotetext{
${ }^{203}$ SARLET, Ingo Wolfgang. op. cit., p. 151.
}

${ }^{204}$ Id. Ibid., p. 61. 
levar a pensar sobre a necessária limitação (naquilo que for possível) da dignidade de um em prol da dignidade do outro ou da coletividade.

Assim, da contraposição de direitos individuais contra direitos coletivos, ambos ligados à dignidade da pessoa humana, em princípio, entendemos que o segundo se sobrepõe ao primeiro.

De igual forma, do confronto de direitos fundamentais de escalas hierárquicas divergentes, sempre será concedida prioridade para garantias de maior relevância, cujo bem tutelado é mais caro para a própria existência humana. Nessa hipótese, a vida colocase no plano mais elevado por constituir o substrato físico da titularidade dos direitos fundamentais. A saúde e a segurança também ocupam posição destacada. No entanto, a segurança não deve ser concebida sob a ótica meramente patrimonial, sendo que a noção de segurança que se busca proteger é a relacionada com o bem-estar do indivíduo e da coletividade.

Como exemplo, indicamos situações de risco para terceiros, em que há um interesse maior (que é a vida e/ou a saúde de terceiros) onde entendemos ser possível sustentar a realização de determinados exames médicos.

Cumpre esclarecer que não estamos sustentando que nas hipóteses em que estiverem em jogo garantias constitucionais de igual ou maior relevância haverá prevalência destas sobre o direito à privacidade. $\mathrm{Na}$ realidade, defendemos que nessas hipóteses é possível a limitação proporcional desse direito da personalidade de forma a garantir a manifestação da outra garantia constitucional envolvida.

A ponderação sempre deverá ser realizada caso a caso, não podendo ser estabelecida uma regra geral de prevalência.

Por fim, cabe novamente defender que entendemos que o direito de propriedade, apesar de ser um direito fundamental arrolado pelo artigo $5^{\circ}$ da Constituição Federal, está em patamar inferior à privacidade, não admitindo, portanto, a sua ponderação na relação de emprego de forma a possibilitar a limitação do direito à privacidade. 


\subsubsection{Quando for condição para a execução do próprio contrato}

Partindo-se de premissa de que ao firmar um contrato de trabalho o empregado está, ainda que implicitamente, consentindo com a limitação da sua liberdade e da sua autonomia, existem situações em que uma maior restrição aos direitos fundamentais do trabalhador impõe-se como condição para a execução do próprio contrato, seja porque imposta por lei, seja porque decorre da ponderação de bens de interesse de igual ou maior relevância, observado o raciocínio anteriormente exposto.

Portanto, é possível também admitir a limitação da privacidade em razão de aspectos imprescindíveis para execução do próprio contrato. No entanto, o contrato deve ser interpretado de acordo com o seu valor social e terá como limitador todos os aspectos apontados no capítulo 2 (limitadores do poder diretivo), de forma a permitir apenas a restrição da privacidade quando decorrente de questões técnicas indispensáveis para a execução do próprio contrato e não de um puro e simples resguardo da propriedade do empregador.

Ou seja, a limitação dos direitos fundamentais do empregado deve ocorrer apenas dentro de uma lógica para o imprescindível desenvolvimento do contrato, principalmente em razão das suas questões técnicas. Por esse raciocínio, a limitação da privacidade pode ocorrer em casos muito especiais, de forma que sem essa limitação o próprio poder de direção - ou até mesmo, o contrato de trabalho - estaria prejudicado. São situações que decorrem da atividade executada e não da propriedade do empregador. Nessas hipóteses, a limitação da privacidade do empregado é praticamente um requisito essencial para a própria execução do contrato de trabalho.

Um bom exemplo da situação que se coloca é o caso já mencionado das instituições financeiras, que são obrigadas por lei a estabelecer sistemas ostensivos e eletrônicos de vigilância. Os empregados destes estabelecimentos, ao firmarem contrato de trabalho, já devem ter ciência que não poderão vindicar o resguardo dessa manifestação da sua privacidade. Outro exemplo é a situação também já mencionada dos vigilantes que, por lei, são obrigados a realizar testes mentais e psicotécnicos e a apresentar atestado de antecedentes criminais sem registros anteriores. Mais uma situação é a do empregado que é contratado para trabalhar em indústria farmacêutica, mantendo contato com substâncias de uso controlado, cujo controle de distribuição é de responsabilidade do empregador. Em 
razão das normas da Agência Nacional de Vigilância Sanitária (ANVISA) e das disposições do Código Penal, o empregador é responsável por guardar e monitorar o acesso a esses produtos, sob pena de ser responsabilizado civil e criminalmente, razão pela qual entendemos que está autorizado a adotar todas as medidas necessárias para garantir que esses medicamentos não saiam do âmbito da sua fábrica, o que poderá compreender a realização de revista pessoal ou monitoramento eletrônico do ambiente de trabalho. ${ }^{205}$

Nas situações acima apontadas, não há como negar a possibilidade de limitação da privacidade, principalmente porque a obrigação contratual está embasada na lei a que se submete o empregador e decorre de um dever maior (segurança à coletividade imposta por lei).

Cumpre destacar que a limitação da privacidade sob esse fundamento ocorre somente nos casos estritamente necessários, onde a lei ou interesses maiores em jogo condicionarem uma limitação aos direitos fundamentais do empregado como obrigação sine qua non para a execução do próprio contrato.

O limite deve ser dado pelo próprio contrato de trabalho ou pela lei. Ou seja, como medida técnica necessária para o cumprimento da avença contratual. Ou, ainda, o limite deve existir quando outras garantias constitucionais de igual valor estiverem em jogo (a vida, a segurança, ou a saúde do próprio trabalhador, do empregador ou de terceiros).

\subsubsection{Quando houver forte e concreto indício de má-fé por parte do empregado}

Uma das obrigações decorrentes do contrato é a sua execução de boa-fé, conforme o princípio que se extrai do artigo 422 do Código Civil. ${ }^{206}$ Tendo a relação de emprego e o poder diretivo uma origem contratual, a execução do contrato de trabalho e o exercício do poder de direção devem pautar-se pela boa-fé, conforme já sustentado no capítulo 2 da presente dissertação.

Paulo Eduardo Vieira de Oliveira destaca que o princípio da boa-fé tem um sentido muito especial na execução do contrato de trabalho, em razão do componente pessoal nele existente. Isso porque o contrato de trabalho não gera direitos e obrigações de cunho

\footnotetext{
${ }^{205}$ Os exemplos ora apresentados serão melhor analisados no capítulo 4, quando tratarmos das situações específicas de concretização da privacidade.

${ }^{206}$ Art. 422. Os contratantes são obrigados a guardar, assim na conclusão do contrato, como em sua execução, os princípios de probidade e boa-fé.
} 
exclusivamente patrimonial, criando, também, vínculos pessoais. O contrato de trabalho estabelece entre as partes uma relação estável e continuada que exige confiança recíproca em múltiplos planos, implicando a convicção de que o negócio jurídico estabelecido será cumprido normalmente, sem trapaças, abusos ou desvirtuamentos. Assim, tanto empregador quanto empregado têm obrigação de agir de boa-fé, concedendo à parte contrária a confiança necessária para a execução das respectivas obrigações. ${ }^{207}$

Sob esse raciocínio, sempre que houver forte e concreto indício de má-fé por parte do empregado, é possível sustentar que o empregador possui a faculdade de exercer o seu poder diretivo de forma mais ampla, fiscalizando e controlando a atividade do trabalhador, a fim de verificar se houve quebra desta confiança. Isso autorizaria a verificação de mensagens de e-mail ou a instalação de sistemas de gravação por vídeo quando houvesse forte e concreto indício de má utilização do correio eletrônico corporativo da empresa ou suspeita de furto.

Via de regra, o poder fiscalizatório do empregador deve ser exercido mediante instrumentos que não afrontem a privacidade do empregado. No entanto, em algumas situações muito específicas entendemos ser possível limitar o pleno gozo da privacidade, quando houver forte e concreto indício de quebra de confiança ou boa-fé, ou, ainda, indicativos de que o objeto do contrato de trabalho está sendo desvirtuado, não existindo outros meios para se averiguar a efetiva quebra de confiança.

Há de ser reforçado, também, que o indício de quebra de confiança aqui referido deve ser forte e concreto, não se baseando em uma mera suspeita. Para tanto, impõe-se a fixação de critérios objetivos prévios e expressos entre as partes para que a existência de “indícios" não esteja condicionada ao livre arbítrio do empregador. Sobre a questão dos critérios objetivos, o tema será melhor explorado no capítulo 4, quando tratarmos do monitoramento de e-mail e internet no ambiente de trabalho.

De igual forma, o exercício do poder diretivo nesses casos - que será, na maioria das vezes, externado pelo poder fiscalizatório do empregador - deverá ser exercido de boafé, de forma a garantir ao máximo a privacidade do trabalhador, evitando-se, assim, o abuso de direito patronal.

Assim, os limites à fiscalização do empregador devem ser realizados através de critérios formais de procedimento, que devem ser objetivamente indicados. Estes requisitos

\footnotetext{
${ }^{207}$ OLIVEIRA, Paulo Eduardo Vieira. O dano pessoal no direito do trabalho, cit., p. 88-89.
} 
formais são elementos que permitem o respeito à intimidade do empregado, evitando abusos do empregador e, ao mesmo tempo, possibilitam o exercício da vigilância que lhe é facultada e atribuída.

Por esse raciocínio, o empregador que, por exemplo, arrombar o armário pessoal por suspeita de má-fé do empregado, estará abusando do seu direito por tal ato implicar um completo desrespeito à dignidade do trabalhador.

A limitação da privacidade sob esse argumento, portanto, deverá ser aplicada em situações excepcionais e com muita cautela.

\subsubsection{Quando houver indício de má utilização dos instrumentos de trabalho de forma a causar prejuízos a terceiros}

A obrigação do empregador de preservar terceiros alheios ao contrato de trabalho contra atos danosos praticados por seus empregados representa um interesse maior e público, autorizando que o empregador exerça o seu poder/dever de fiscalização para evitar que os instrumentos de trabalho fornecidos não sejam utilizados de forma ilícita ou de maneira a causar prejuízo a terceiros.

Assim, a obrigação do empregador em preservar a sociedade em geral contra atos ilícitos praticados por seus empregados durante a jornada laboral - que decorre do direito de propriedade exercido dentro da sua função social - representa um interesse maior preservado e, portanto, capaz de justificar a limitação da privacidade dos empregados.

Não estamos conferindo ao empresário poder de polícia. Na realidade, estamos falando do exercício do poder/dever de fiscalização do empregador que é conferido pelo contrato de trabalho e pela responsabilidade atribuída pelo inciso III do artigo 932 do Código Civil.

Um exemplo prático dessa obrigação consiste no trabalho desenvolvido pelas empresas de banco de dados. Os trabalhadores que têm acesso a dados confidenciais e pessoais dos clientes dos seus empregadores têm o dever de manter o sigilo dessas informações. O vazamento ou a divulgação desses dados (informações bancárias e de crédito, cadastros pessoais, etc.) afrontará direitos personalíssimos de terceiros, causando prejuízos a estes. 
Desta forma, o empregador tem o dever de estabelecer mecanismos de proteção contra atos de seus empregados capazes de causar prejuízos a terceiros, estando autorizado a limitar o exercício pleno da privacidade do trabalhador.

A fiscalização do empregador deve ser realizada através de critérios formais de procedimento, que devem ser objetivamente e previamente estipulados. Estes requisitos formais são elementos que permitem o respeito à intimidade do empregado, evitando abusos do empregador e, ao mesmo tempo, possibilitam o exercício da vigilância que lhe é facultada e atribuída. Caso contrário, a subjetividade abriria a possibilidade de arbitrariedades e abusos patronais.

\subsection{Premissas para que a limitação à privacidade ocorra sem abusos por parte do empregador}

Estabelecidas as exceções à regra geral de tutela da privacidade do empregado, entendemos que estas somente podem ser consideradas válidas se forem exercidas de forma ponderada e criteriosa.

Para acolhermos a possibilidade de limitação da privacidade do empregado sem prejuízo a esse direito da personalidade, faz-se necessário o estabelecimento de algumas regras basilares, ou seja, de premissas que deverão ser obrigatoriamente observadas pelo empregador. Caso contrário, restará configurado o abuso de direito passível de reparação, conforme será tratado no capítulo 5 do presente trabalho.

Vejamos essas premissas, que se aplicam a todas as hipóteses de exceção apontadas no item 3.4 acima:

\subsubsection{Respeito máximo e limitação mínima - manutenção do núcleo essencial da privacidade, como expressão da dignidade da pessoa humana}

É possível admitir a limitação de um direito fundamental, mas não a ponto de este ser completamente esvaziado ou suprimido. Ou seja, nas hipóteses em que se admite a limitação da privacidade, esta restrição não pode acarretar o esvaziamento ou supressão do 
direito fundamental do trabalhador, devendo ser garantida a efetivação do núcleo essencial do direito objeto da restrição.

Partindo-se da premissa de que a dignidade da pessoa humana é núcleo essencial do direito à privacidade, a limitação a este direito somente pode ocorrer nas hipóteses em que a dignidade do trabalhador não for afetada. Ou seja, a limitação pode ocorrer até o limite de não se atingir a dignidade de pessoa humana, pois o "conteúdo de dignidade da pessoa humana em cada direito fundamental encontra-se imune a restrições." 208

Assim, o exercício do poder diretivo deve sempre respeitar ao máximo - sem que isso represente a sua descaracterização - os direitos da personalidade do empregado, dentre eles, a privacidade. A limitação deve ocorrer de forma a respeitar o mínimo do direito fundamental, ou seja, o seu núcleo essencial. Mesmo com a limitação, deve haver a proteção mínima dos direitos fundamentais do trabalhador, notadamente a sua dignidade.

O Código do Trabalho de Portugal, ao concretizar os direitos da personalidade das partes envolvidas na relação de emprego, utiliza essa premissa, pois mesmo concebendo a limitação destes direitos em algumas situações, não possibilita a limitação total do seu exercício. Conforme será visto no capítulo 4, dependendo dos outros direitos em jogo, o legislador português aceita a limitação dos direitos da personalidade no ambiente de trabalho, sem, contudo, restringir totalmente o seu efetivo exercício.

Portanto, não há ação legítima do empregador diante dos direitos fundamentais do empregado quando não respeitados os limites mínimos de sua tutela. ${ }^{209}$

Na ponderação dos direitos envolvidos, deve-se buscar sempre a máxima garantia dos direitos fundamentais do trabalhador, sem que isso represente a exclusão do outro direito ou negação da própria harmonia da relação jurídica.

O posicionamento ora apresentado pretende conciliar as garantias e direitos envolvidos, através da máxima observância com a mínima restrição, estabelecendo um padrão razoável de segurança para o empregado.

\footnotetext{
${ }^{208}$ SARLET, Ingo Wolfgang. op. cit., p. 136.

${ }^{209}$ REZENDE, Roberto Vieira de Almeida. op. cit., p. 193.
} 


\subsubsection{A limitação deve ser imprescindível, adequada e proporcional, não sendo possível a obtenção do mesmo fim por outros meios}

A limitação dos direitos de personalidade do empregado deve ocorrer quando imprescindível para a execução técnica do próprio contrato ou quando outros interesses de igual ou maior relevância estiverem em jogo. Qualquer restrição aos direitos fundamentais deve ser indispensável e absolutamente necessária, sob pena de configuração de abuso de direito.

Os meios utilizados pelo empregador devem ser adequados para a finalidade a que se destina. Por esse raciocínio, se o empregador tem o dever de utilizar sistemas de vigilância para a segurança de seus clientes, está autorizado a utilizar sistema interno de câmeras, mas não pode extrapolar o seu direito utilizando equipamentos que ultrapassam as vestes dos empregados (aparelhos de raio-x atualmente utilizados em alguns aeroportos americanos para evitar ameaças terroristas).

De igual forma, há de existir uma razoável proporcionalidade entre o benefício que a empresa recebe e o prejuízo acarretado ao trabalhador e se não há outras possibilidades de satisfazer aquele interesse sem provocar este prejuízo. Se existir outra forma de se chegar ao mesmo fim, sem que a privacidade do trabalhador seja limitada, esta alternativa deverá ser obrigatoriamente buscada pelo empregador.

Desta forma, a limitação da privacidade somente será aceita se for imprescindível, se estiver fundamentada em justificativa razoável, e se for adequada e proporcional, não podendo ser obtida por outros meios.

\subsubsection{Empregado deve ter conhecimento prévio do instrumento utilizado para limitar a privacidade, com a sua respectiva justificativa por parte do empregador, devendo autorizar expressamente a limitação}

O dever de boa-fé, transparência e informação inerentes ao contrato de trabalho obrigam que as práticas eventualmente adotadas pelo empregador para limitar o pleno resguardo da privacidade no ambiente de trabalho sejam prévia e expressamente 
comunicadas pelo empregador e aceitas pelo trabalhador, sendo que nessa comunicação devem ser indicados os motivos e a justificativa para tal limitação.

A premissa ora defendida é inspirada no Código do Trabalho português, que impõe ao empregador a obrigação de comunicar previamente por escrito, e com a indicação dos motivos patronais, a prática que será adotada para limitar a esfera privada do trabalhador.

A ciência prévia do trabalhador apresenta-se como o primeiro requisito a ser observado, para que se estabeleça uma definição razoável da prática restritiva que será adotada pelo empregador, devendo constar em quais circunstâncias haverá a limitação. Entretanto, a ciência prévia não é suficiente para afastar o problema da oposição entre os interesses dos empregados e dos empregadores.

Somente através da utilização de critérios objetivos - onde restar estabelecido, de forma clara, as circunstâncias da fiscalização - é possível respeitar a dignidade do empregado.

Assim, deve ser exposto previamente ao empregado o motivo e em quais situações a verificação será realizada, sendo vedada a limitação em outras hipóteses que não previamente informadas e justificadas.

Da necessidade de informação prévia decorre o dever do empregador de somente adotar práticas restritivas de direitos da personalidade quando estas forem expressamente autorizadas pelo empregado. Por mais que se questione a autonomia do empregado nesta manifestação de vontade, a imposição desta obrigação visa proporcionar ao empregado, ainda que de forma acanhada, a possibilidade de se opor à prática pretendida pelo empregador.

A participação e assistência do sindicato ou do Ministério Público do Trabalho na manifestação deste ato de vontade é importante para garantir a livre manifestação da vontade do empregado

Quanto à necessidade de concordância escrita, podemos utilizar, por analogia, a regra prevista no artigo 468 da Consolidação das Leis do Trabalho, por meio da qual qualquer alteração contratual somente poderá ser realizada se contar com a concordância expressa do empregado e, mesmo sob essa condição, desde que não ocasione prejuízos a este. Assim, mesmo que o empregado concorde expressamente com a limitação, essa manifestação de vontade será considerada nula se não garantir a preservação do núcleo essencial do direito limitado. 


\subsubsection{O instrumento de limitação deve ser negociado com entidades representantes dos trabalhadores (comissão de fábrica, sindicato) e, na ausência destes, deverá contar com a anuência do Ministério Público do Trabalho}

Conforme exposto acima, diante da natural limitação da autonomia e liberdade do trabalhador em razão da sua hipossuficiência, a premissa anterior (autorização expressa do empregado para a prática de limitação) é mais efetiva se a entidade de representação do trabalhador estiver envolvida na definição dos procedimentos que acabarão acarretando na limitação da privacidade. Além do seu envolvimento, a entidade deve efetivamente anuir com as práticas a serem adotadas pelo empregador.

Na impossibilidade de envolvimento da entidade representativa dos trabalhadores, $o$ Ministério Público do Trabalho deverá, obrigatoriamente, anuir com a prática pretendida pela empresa, de forma a evitar abusos por parte do empregador, garantindo, também, maior legitimidade à manifestação de vontade a ser externalizada pelos empregados, indicando a concordância com a prática a ser adotada pela empresa.

\subsection{Necessidade de aplicação do conceito geral para o caso concreto}

Conforme exposto, a concretização da privacidade do trabalhador no ambiente de trabalho deve coexistir com os demais direitos envolvidos na dinâmica do trabalho, sem deixar de se considerar que o objetivo, antes de tudo, é a proteção do indivíduo.

Do confronto dos direitos envolvidos, a concretização da privacidade não pode anular integralmente o poder de direção do empregador, sob pena de descaracterização da natureza da própria relação de emprego. No entanto, através da observação dos princípios da dignidade da pessoa humana, finalidade, pertinência, proporcionalidade, simplificação, harmonização e necessidade, a adoção de práticas pelo empregador para o exercício do seu poder diretivo deve estar limitada ao mínimo necessário para garantir a maior liberdade possível ao empregado, observando-se, também, a finalidade perseguida. Assim, somente se aceita a limitação à privacidade do empregado por parte do empregador quando a finalidade assim justificar, sendo que as razões devem ser objetivas e o objeto da averiguação deve ser limitado. 
Apesar do conceito geral ora proposto, não há, entretanto, uma fórmula previamente estabelecida para determinar a solução da colisão de direitos. A solução das colisões entre a privacidade do empregado e o exercício do poder diretivo de empregador é casuística. Assim, a fim de ilustrar a concretização da privacidade do trabalhador no ambiente de trabalho, o presente trabalho passará a apresentar no próximo capítulo exemplos desses conflitos e qual a solução que se propõe - considerando as convicções ora apresentadas - para garantir a concretização da privacidade do empregado sem afastar os outros interesses em jogo, quais sejam, o exercício do poder diretivo do empregador e impossibilidade de afronta ou negação de outros direitos fundamentais existentes (caso da vida, liberdade, saúde, segurança, etc.). 


\section{A CONCRETIZAÇÃo dA PRIVACIDAdE NO AMBIENTE DE TRABALHO}

Após o estabelecimento dos conceitos e das bases necessárias para a compreensão da privacidade do empregado e do poder diretivo do empregador, bem como da possibilidade de coexistência de ambos os direitos na relação de emprego sem que isso represente uma afronta à esfera privada do trabalhador, utilizaremos as condições e premissas apresentadas no capítulo 3 para demonstrar, em exemplos práticos, como a concretização da privacidade no ambiente de trabalho deverá ser perquirida.

Conforme já sustentado, apesar de inexistirem dispositivos legais expressos no direito do trabalho nacional disciplinando o tratamento da privacidade do trabalhador, ${ }^{210} \mathrm{o}$ conceito geral extraído da Constituição e da legislação ordinária vigente, realizado através da interpretação e ponderação com os outros direitos em jogo, é suficiente para garantir a concretização da privacidade do trabalhador.

Pensar de forma contrária e negar a concretização desse direito fundamental, representa a negação da própria dignidade do ser humano. ${ }^{211}$

A concretização da privacidade no contrato de trabalho deverá ser considerada em seu aspecto temporal mais amplo, abrangendo todas as fases da relação de emprego. As possibilidades de violação da esfera privada do trabalhador não estão limitadas ao momento da execução do contrato, podendo também ocorrer na fase de pré (processo seletivo e estabelecimento das condições laborais) e pós-contratual.

Especialmente quanto à fase pré-contratual, a discussão sobre a possibilidade de ocorrer violação da privacidade do empregado nesse período escapou durante muito tempo de uma análise mais atenta por parte da doutrina e jurisprudência. No âmbito nacional, certamente tal situação se deve ao fato de somente em dezembro de 2004, com a edição da Emenda Constitucional n. 45, a Justiça do Trabalho ter sido considerada competente para apreciar e julgar matéria de dano moral na relação de emprego.

A fase pré-contratual não pode ser ignorada, merecendo a tutela do direito do trabalho e, principalmente, a tutela do direito geral de personalidade do trabalhador, visto que esta é uma das fases em que a desigualdade entre as partes que compõem a relação de

\footnotetext{
${ }^{210}$ Com exceção de pouquíssimos artigos, conforme visto na capítulo 1 do presente trabalho.

${ }^{211}$ SARLET, Ingo Wolfgang. op. cit., p. 97.
} 
emprego é mais visível. É inegável que, salvo raríssimas exceções, o candidato à vaga de emprego está em desvantagem econômica e social (pois necessita do emprego para a sua sobrevivência), e o empregador está em situação mais vantajosa, pois poderá facilmente descartar qualquer candidato e substituí-lo por outro, o que torna o primeiro muito mais vulnerável que o segundo. Desta situação de desequilíbrio decorre a necessidade de verificar quais os limites do empregador na fase pré-contratual, de forma a proteger a pessoa do candidato ao emprego na fase de recrutamento e seleção.

De qualquer sorte, independente da fase contratual, certo é que a privacidade do empregado deverá ser garantida, mesmo que ponderados os demais direitos envolvidos.

A seguir, a partir da indicação de algumas situações práticas de vulnerabilidade da privacidade do trabalhador apontaremos quais os procedimentos que, de acordo com as premissas indicadas no capítulo anterior, recomendamos ser adotados de forma a garantir a efetiva concretização desse direito da personalidade sem que isso represente a negação dos demais direitos envolvidos.

O rol a ser apresentado não tem a pretensão de exaurir as inúmeras possibilidades de violação da privacidade no ambiente de trabalho, tendo tomado por base as práticas atualmente mais adotadas no mercado de trabalho.

Por fim, destacamos que, das hipóteses ora apresentadas, algumas (a exemplo da realização de testes e exames) poderão ocorrer em mais de uma fase contratual, razão pela qual a presente dissertação não dividiu as situações a serem analisadas em fases pré, inter e pós-contratual. De qualquer forma, a grande maioria das ocorrências se dá na fase de execução do contrato, principalmente porque é nessa fase que eclode o exercício do poder diretivo do empregador.

\subsection{Realização de testes e exames médicos}

\subsubsection{Testes e exames de gravidez}

A exigência da realização de testes ou exames de gravidez para a contratação ou a manutenção do contrato representa uma violação da privacidade da empregada, além de ter caráter flagrantemente discriminatório. Tal prática, portanto, é completamente vedada ao empregador. 
O legislador ordinário, em uma das poucas referências realizadas aos direitos da personalidade do trabalhador, incluiu o artigo 373-A na Consolidação das Leis do Trabalho $^{212}$ proibindo expressamente a exigência de atestado ou da realização de exames de qualquer natureza para a comprovação de esterilidade ou gravidez. Tal disposição se coaduna com a previsão contida no artigo $391^{213}$ da Consolidação das Leis do Trabalho, que estipula que o fato de a mulher ter se casado ou estar grávida não constituem motivos para a rescisão do seu contrato de trabalho, proibindo, também, a existência de regulamentos, normas coletivas ou contratos de trabalho restringindo o direito da mulher ao emprego por tais motivos.

Quanto ao tema, o legislador foi além, chegando a ponto de tipificar como crime a prática discriminatória de exigência de teste ou qualquer outro documento com a finalidade de atestar ou não estado de gravidez da trabalhadora no inciso I do artigo $2^{\circ}$ da Lei 9.029/95. Ainda relacionado à gravidez, o inciso II do artigo $2^{\circ}$ da mesma lei dispõe que também constitui crime a adoção de qualquer medida capaz de induzir ou instigar a esterilização genética ou controle de natalidade. ${ }^{214}$

O Code du Travail francês também contém previsão expressa sobre a matéria no artigo L1225-1, que proíbe o empregador solicitar ou obter informações sobre eventual gravidez da mulher. Já o artigo L1225-2 do Código determina que a candidata à vaga de emprego não é obrigada a revelar o seu estado gravídico, salvo se estiver requerendo o benefício das disposições legais que protegem as mulheres grávidas.

O Código do Trabalho de Portugal cuidou, também, de dispor expressamente sobre o tema, sendo que o seu artigo 19.2 determina que "O empregador não pode, em

\footnotetext{
${ }^{212}$ Art. 373-A. Ressalvadas as disposições legais destinadas a corrigir as distorções que afetam o acesso da mulher ao mercado de trabalho e certas especificidades estabelecidas nos acordos trabalhistas, é vedado: (...) IV - exigir atestado ou exame, de qualquer natureza, para comprovação de esterilidade ou gravidez, na admissão ou permanência no emprego (...)

${ }^{213}$ Art. 391. Não constitui justo motivo para a rescisão do contrato de mulher o fato de haver contraído matrimônio ou de encontrar-se em estado de gravidez.

Parágrafo Único. Não serão permitidos em regulamentos de qualquer natureza, contratos coletivos ou individuais de trabalho, restrições ao direito da mulher ao seu emprego, por motivo de casamento ou de gravidez.

${ }^{214}$ Art. $2^{\circ}$ Constituem crime as seguintes práticas discriminatórias:

I - a exigência de teste, exame, perícia, laudo, atestado, declaração ou qualquer outro procedimento relativo à esterilização ou a estado de gravidez;

II - a adoção de quaisquer medidas, de iniciativa do empregador, que configurem;

a) indução ou instigamento à esterilização genética;

b) promoção do controle de natalidade, assim não considerado o oferecimento de serviços e de aconselhamento ou planejamento familiar, realizados através de instituições públicas ou privadas, submetidas às normas do Sistema Único de Saúde (SUS).

Pena: detenção de um a dois anos e multa.
} 
circunstância alguma, exigir a candidata a emprego ou a trabalhadora a realização ou apresentação de testes ou exames de gravidez", estabelecendo como contra ordenação muito grave a violação dessa regra.

Os dispositivos legais acima invocados são absolutamente imperativos, não sendo admitida a sua derrogação ou limitação, em razão da garantia da dignidade da pessoa humana.

No caso da legislação brasileira, a existência de expressa proibição legal quanto à realização do exame de gravidez impede qualquer possibilidade de limitação ao direito da trabalhadora. Se o artigo 11 do Código Civil somente possibilita a limitação dos direitos da personalidade quando houver previsão legal, a contrário sensu, devemos entender como completamente vedada a mitigação desse direito quando houver norma expressa impedindo esse ato.

A informação sobre o estado gestacional da empregada possui caráter personalíssimo, sendo que qualquer intromissão do empregador nessa esfera de resguardo representará uma violação de privacidade da trabalhadora, além de dar margem à adoção de atos patronais discriminatórios.

A proibição da realização de testes de gravidez não admite, portanto, qualquer exceção ou limitação, mesmo nas situações em que a função para a qual a empregada está se candidatando está exposta a condições de risco. Nessas hipóteses, é até possível discutir se a empregada tem o dever ou não de informar sobre o seu estado gravídico ${ }^{215}$; no entanto, a imposição patronal para a realização de exames para comprovar essa condição jamais deverá ser admitida.

A dignidade da pessoa humana, o princípio geral de igualdade e não discriminação e a garantia fundamental de proteção da esfera íntima da trabalhadora, além da expressa vedação legal, não admitem qualquer sopesamento ou ponderação de interesses do empregador.

\footnotetext{
${ }^{215}$ Esse tema será melhor analisado no item 4.3 do presente trabalho.
} 


\subsubsection{Testes e exames médicos}

Da verificação da prática empresarial, é possível constatar a existência de três tipos de exames médicos que podem ser realizados nas três fases contratuais (admissão, execução e rescisão), a saber: exames determinados pela legislação, exames de qualquer natureza não previstos na legislação e testes toxicológicos.

\subsubsection{Exames médicos determinados por Lei}

O artigo 168, da Consolidação das Leis do Trabalho, ${ }^{216}$ obriga o empregado a realizar exame médico admissional, periódico e demissional, mesmo contra a sua vontade. A Norma Regulamentadora n. 7 (NR-7) incluiu como obrigação do Programa de Controle Médico de Saúde Ocupacional - $\mathrm{PCMSO}^{217}$ a realização de exames médicos na admissão, periodicamente, no retorno ao trabalho, nas hipóteses de mudança de função e na demissão, sendo que esses exames compreendem exames comuns a todos os trabalhadores e exames complementares aplicáveis a categorias de trabalhadores e funções específicas para a verificação de patologias específicas do trabalho em razão das atividades desenvolvidas. $^{218}$

O caput do artigo 225 da Constituição Federal ${ }^{219}$ garante o direito e impõe o dever de todos a um meio ambiente sadio. A concepção de meio ambiente incluiu o meio ambiente do trabalho. Desta previsão decorre o princípio geral que impõe ao empregador a responsabilidade pela adoção e custeio das práticas necessárias para a preservação do

\footnotetext{
${ }^{216}$ Art. 168. Será obrigatório exame médico, por conta do empregador, nas condições estabelecidas nesse artigo e nas instruções complementares a serem expedidas pelo Ministério do Trabalho:

I - na admissão;

II - na demissão;

III - periodicamente.

${ }^{217} 7.4 .1$ O PCMSO deve incluir, entre outros, a realização obrigatória dos exames médicos:

a) admissional;

b) periódico;

c) de retorno ao trabalho;

d) de mudança de função;

e) demissional.

2187.4.2 Os exames de que trata o item 7.4.1 compreendem:

a) avaliação clínica, abrangendo anamnese ocupacional e exame físico e mental;

b) exames complementares, realizados de acordo com os termos específicos nesta NR e seus anexos.

${ }^{219}$ Art. 225. Todos têm direito ao meio ambiente ecologicamente equilibrado, bem de uso comum do povo e essencial à sadia qualidade de vida, impondo-se ao Poder Público e à coletividade o dever de defendê-lo e preservá-lo para as presentes e futuras gerações.
} 
ambiente do trabalho. O trabalhador, por sua vez, tem o dever de se submeter aos exames e adotar as medidas recomendadas para a proteção da vida e saúde própria e dos demais colegas.

Assim, o empregador tem o dever de propiciar a realização dos exames genéricos e específicos nos seus empregados, podendo, inclusive, ser penalizado caso não proceda aos exames determinados por lei; e o empregado, por sua vez, não poderá se eximir de se submeter a estes exames.

A obrigatoriedade à submissão ao exame não retira do empregado o direito ao resguardo da sua privacidade, sendo que o resultado do exame deve ser comunicado diretamente ao trabalhador, observados os preceitos da ética médica, conforme determina o parágrafo $5^{\circ}$ do artigo 168 da Consolidação das Leis do Trabalho. Sob o mesmo raciocínio, ainda que o empregador seja obrigado a submeter os seus empregados ou candidatos a emprego a alguns tipos de exames, isso não lhe confere a prerrogativa de ter acesso a esses exames, pois a ele interessa apenas saber se existe ou não aptidão para a função oferecida ou desempenhada pelo trabalhador.

O papel do médico é muito importante para a preservação da privacidade do trabalhador, pois a ele cabe o acesso e a divulgação da informação sobre a saúde do empregado, devendo manter sigilo sobre essas informações e fornecer ao empregador somente o necessário para indicar se existe ou não aptidão para o trabalho. Trata-se do sigilo profissional médico imposto nos artigos 73 e 76 da Resolução do Conselho Federal de Medicina n. 1.931, de 17 de setembro de 2009 (Código de Ética Médica) ${ }^{220}$, cuja quebra é tipificada como crime pelo artigo 154 do Código Penal.

A vedação de divulgação dos resultados dos exames aplica-se, inclusive, na esfera judicial, visto que o artigo 89 do Código de Ética Médica ${ }^{221}$ impede a liberação de cópias

\footnotetext{
${ }^{220}$ É vedado ao médico: (...) Art. 73. Revelar fato de que tenha conhecimento em virtude do exercício de sua profissão, salvo por motivo justo, dever legal ou consentimento, por escrito, do paciente. (...)

Art. 76. Revelar informações confidenciais obtidas quando do exame médico de trabalhadores, inclusive por exigência dos dirigentes de empresas ou de instituições, salvo se o silêncio puser em risco a saúde dos empregados ou da comunidade. - Inteiro teor da Resolução CFM 1.931/2009 obtida através do site CREMESP.

Disponível

em: <http://www.cremesp.org.br/library/modulos/legislacao/versao_impressao.php?id=8822>. Acesso em: 20 dez. 2010.

${ }^{221}$ É vedado ao médico: (...) Art. 89. Liberar cópias do prontuário sob sua guarda, salvo quando autorizado, por escrito, pelo paciente, para atender ordem judicial ou para a sua própria defesa.

$\S 1^{\circ}$ Quando requisitado judicialmente o prontuário será disponibilizado ao perito médico nomeado pelo juiz.

$\S 2^{\circ}$ Quando o prontuário for apresentado em sua própria defesa, o médico deverá solicitar que seja observado o sigilo profissional.
} 
do prontuário que estiver sob a sua guarda, mesmo que determinado por ordem judicial, salvo se for autorizado por escrito pelo paciente. Portanto, a juntada de ficha médica em processo judicial pela empresa, com os resultados dos exames e a ficha de anamnese, acarreta a afronta da privacidade do trabalhador.

A exceção ao sigilo profissional médico especialmente aplicado aos exames médicos laborais está prevista na parte final do artigo 76 da Resolução 1.931/2009, e ocorre quando o silêncio sobre a condição da saúde do trabalhador colocar em risco a saúde dos empregados ou da comunidade. No mesmo sentido, o médico tem obrigação de comunicar às autoridades competentes quaisquer formas de deterioração do ecossistema, prejudiciais à saúde e à vida, conforme princípio elencado no inciso XIII do Código de Ética Médica. Há, também, obrigatoriedade legal de notificação da Vigilância Sanitária em casos de doenças contagiosas.

A divulgação dos resultados dos exames realizados em pessoas com deficiência merece ser concebida de forma diferente, pois nessas hipóteses, por obrigação legal, haverá necessidade de indicação de qual o tipo e grau de deficiência e se a deficiência existente é compatível com a atividade a ser desenvolvida. Contudo, as informações sobre as condições de saúde da pessoa com deficiência repassadas ao empregador devem observar o limite necessário para o atendimento da lei, não se admitindo, sob qualquer hipótese, a extrapolação deste limite.

Por todo o exposto, o fato de os exames médicos serem impostos ou autorizados por lei não afasta o direito à privacidade do empregado, visto que o médico que realiza esses exames tem dever profissional de sigilo, sendo que as informações a serem repassadas ao empregador devem estar limitadas à aptidão ou à inaptidão para o exercício da função, salvo as exceções previstas em lei indicadas acima.

\subsubsection{Exames de qualquer natureza não determinados por Lei - teste de HIV e exames toxicológicos}

Outro enfoque deve ser dado à realização de exames de qualquer natureza não determinados por lei que são realizados em processos de seleção e durante ou após a execução do contrato de trabalho. Tais exames - como teste de HIV, exame para detectar a presença de substâncias ilícitas ou álcool - apesar de não obrigatórios por lei, são 
praticados por alguns empregadores sob o argumento de serem necessários em razão da atividade desenvolvida pelo empregado.

A lei brasileira não veda de forma expressa esses exames, ao contrário do que estabelece a primeira parte do artigo 19.1 do Código do Trabalho de Portugal ${ }^{222}$, que afirma o princípio geral de que o empregador não pode, para efeitos de admissão e permanência do trabalhador no emprego, exigir do empregado a realização ou apresentação de testes ou exames médicos de qualquer natureza para a comprovação das suas condições físicas, salvo se decorrerem de situações previstas na legislação de segurança e higiene e saúde do trabalho. No entanto, a segunda parte do artigo 19.1 do mesmo diploma legal admite limitações a essa regra geral, desde que observados os seguintes requisitos: i) a finalidade do pedido de exames deve estar fundamentada na segurança do trabalhador ou de terceiros ou quando as exigências inerentes à atividade assim exigirem; ii) o empregador deve fornecer, por escrito, ao candidato ou trabalhador a fundamentação que justifica a realização do exame; e iii) a intermediação de um médico.

O artigo 20.4 do Estatuto de los Trabajadores possibilita a verificação particular pelo empregador, através de uma equipe médica, do estado de incapacidade ou lesão que é alegado pelo empregado para justificar a sua ausência ao trabalho, sendo que a recusa do empregado a se submeter a esse exame poderá suspender os direitos econômicos a que o empregado faria jus nessa situação.

A recente Recomendação 200 da Organização Internacional do Trabalho ${ }^{223}$ - que trata sobre a infecção do HIV no mundo do trabalho adotada pela $99^{a}$ Seção da Conferência Internacional do Trabalho, em 17 de junho de 2010 - estabelece que os

\footnotetext{
${ }^{222}$ Testes e exames médicos

1 - Para além das situações previstas em legislação relativa a segurança e saúde no trabalho, o empregador não pode, para efeitos de admissão ou permanência no emprego, exigir ao candidato a emprego ou ao trabalhador a realização ou apresentação de testes ou exames médicos, de qualquer natureza, para comprovação das condições físicas ou psíquicas, salvo quando estes tenham por finalidade a protecção e segurança do trabalhador ou de terceiros, ou quando particulares exigências inerentes à actividade o justifiquem, devendo em qualquer caso ser fornecida por escrito ao candidato a emprego ou trabalhador a respectiva fundamentação.

2 - O empregador não pode, em circunstância alguma, exigir a candidata a emprego ou a trabalhadora a realização ou apresentação de testes ou exames de gravidez.

3 - O médico responsável pelos testes e exames médicos só pode comunicar ao empregador se o trabalhador está ou não apto para desempenhar a actividade.

4 - Constitui contra -ordenação muito grave a violação do disposto nos n.os 1 ou 2.

${ }^{223} \mathrm{O}$ inteiro teor da Recomendação 200 da OIT foi obtido em: INTERNATIONAL LABOUR ORGANIZATION. Conferência Internacional do Trabalho. Recomendação 200. Recomendação sobre a infecção VIH e SIDA e o mundo do trabalho, adoptada pela Conferência Internacional do Trabalho na sua nonagésima nona sessão, em Genebra, a 17 de junho de 2010. Disponível em: $<$ http://www.ilo.org/public/portugue/region/eurpro/lisbon/pdf/recomendacao_200.pdf> Acesso em: 05 dez. 2010.
} 
portadores de HIV, bem como os seus familiares, deverão ter a sua privacidade garantida, também não sendo permitido que o empregador obrigue qualquer trabalhador ou candidato à vaga de emprego a se submeter a teste de HIV. No entanto, ao mesmo tempo em que a Recomendação proíbe a imposição dos exames, determina que o empregador tem o dever de adotar medidas necessárias para a proteção de seus empregados que, em razão das atividades desenvolvidas, estão mais expostos aos riscos de infecção pelo vírus.

Pelo raciocínio da Recomendação em questão, é possível sustentar que os empregados que estão expostos, em razão das peculiaridades de suas atividades, a uma maior incidência ao vírus HIV, devem se submeter frequentemente ao exame para sua detecção, como medida de proteção da sua saúde. Atualmente, sabe-se que quanto mais cedo o vírus é detectado, maior a probabilidade de não manifestação da doença e de expectativa e qualidade de vida do portador do vírus. Desta forma, pela aplicação da própria recomendação da OIT é possível sustentar a possibilidade de submissão dos empregados ao teste do HIV em situações muito particulares, quando estas decorrerem do exercício do próprio contrato de trabalho, estando vinculadas à proteção de um bem maior, que é a preservação da saúde do trabalhador.

Por outro lado, a própria Recomendação 200 da OIT determina que os exames devem ser voluntários e que os dados desses exames devem ser tratados de forma a resguardar a privacidade do trabalhador, restando garantida a confidencialidade dos dados médicos dos empregados.

Em razão da omissão do legislador ordinário nacional em matéria de direito do trabalho, a doutrina e a jurisprudência têm utilizado a previsão constitucional para resolver casos concretos. Com relação a exames não obrigatórios por lei, a discussão doutrinária e jurisprudencial se dá, na maioria das vezes, com relação à realização de testes para detecção do vírus HIV ou exames toxicológicos, sendo que existe uma corrente que sustenta não ser possível a realização destes exames, por afrontarem a intimidade do empregado, e outra corrente que admite esse tipo de teste quando a natureza da atividade assim demandar.

Julio Manuel Vieira Gomes, por exemplo, apesar de fazer referência à legislação portuguesa, aceita a realização de exames toxicológicos em situações excepcionais, apresentando, com base na doutrina de John Craig, os seguintes princípios para que se considere lícito o teste: 
em primeiro lugar, só os trabalhadores que desempenham funções em que exista um risco considerável é que devem ser sujeitos a testes. Além disso, há-de existir uma impossibilidade de supervisão (trata-se, por exemplo, de trabalhadores que trabalham tipicamente fora do estabelecimento ou de situações em que há uma razoável suspeita de que um determinado candidato ou trabalhador usa drogas, até por uma aparente redução de produtividade) não existindo alternativas razoáveis aos testes para averiguar o consumo de droga. Acresce que devem existir garantias procedimentais: aviso prévio do teste, notificação dos resultados logo que possível, verificação dos resultados positivos através de um segundo teste de confirmação, acesso aos resultados antes de qualquer decisão e confidencialidade em relação aos resultados assim obtidos (os resultados dos referidos testes estarão sujeitos ao sigilo médico, limitando-se o médico responsável a comunicar ao empregador a aptidão ou não aptidão para o trabalho. ${ }^{224}$

Alice Monteiro de Barros sustenta que, excepcionalmente, o empregador poderá interferir na vida extracontratual do empregado, quando o seu comportamento colidir com os interesses da empresa. Cita como exemplo dessa hipótese o empregado que trabalha em entidade de auxílio a dependentes alcoólicos e que não poderá tornar pública a ostentação de suas inclinações alcoólicas. ${ }^{225}$

Utilizando as premissas apresentadas no capítulo anterior, temos que qualquer exame admissional ou realizado durante a execução do contrato de trabalho não previsto em lei é, via de regra, ilegal, pois inexiste dispositivo legal expresso que lhe dê suporte.

No entanto, é possível estabelecer algumas exceções a essa regra, principalmente quando o exame a que deve ser submetido o empregado estiver justificado na proteção de um bem ou direito maior, que é a vida do próprio empregado ou de terceiros.

Nesse aspecto, a previsão da legislação portuguesa é muito valiosa, sendo que nos socorremos dela para encontrar uma solução para o presente debate. Com efeito, a redação do artigo 19.1 do Código do Trabalho de Portugal representa a concretização dos critérios sustentados no capítulo anterior deste trabalho, no sentido de estabelecer, como regra geral, a preservação da privacidade do trabalhador através da proibição de exames não previstos na lei, exceto quando estritamente necessários para o exercício da função e desde que a realização destes exames observe critérios definidos em lei.

No caso do HIV, os profissionais da saúde que trabalham constantemente com materiais perfuro-cortantes e com atendimento ao público estão sujeitos a se contaminar e

\footnotetext{
${ }^{224}$ GOMES, Júlio Manuel Vieira. op. cit., v. 1, p. 353.

${ }^{225}$ BARROS, Alice Monteiro de. Curso de direito do trabalho, cit., p. 555.
} 
a contaminarem outros pacientes com o vírus. Apenas para essas situações especialíssimas seria possível a realização de teste de HIV, desde que observados cuidados apontados no capítulo anterior, adicionando, também, a obrigação de confidencialidade destacada no item anterior (aplicável aos exames determinados por lei). Apesar de ser possível sustentar a legalidade do exame nesses casos, não há como aceitar que o empregador tenha o direito de ter acesso a esses exames, pois tal informação é de caráter privado do trabalhador. A Recomendação 200 da OIT deve ser respeitada quanto a este aspecto.

Assim, o tratamento da realização do exame de HIV deve ser realizado de forma muito mais cuidadosa e sigilosa do que outros exames, especialmente em razão do caráter pejorativo e discriminatório com que a doença é tratada pela sociedade.

No que diz respeito aos testes toxicológicos, novamente temos que a regra geral é a sua proibição, sendo possível apenas aceitar a sua realização quando, em razão da natureza da atividade exercida pelo empregado, a realização do exame for imprescindível para garantir a preservação de um direito de igual ou maior relevância e abrangência, como a vida ou a saúde de terceiros, por exemplo.

É o caso do motorista de ônibus, do maquinista, do piloto de avião e atividades afins. O exercício profissional sob o efeito de álcool ou drogas (lícitas ou não) poderá colocar em risco e causar efetivos danos à vida e/ou à saúde de um grande universo de pessoas. A preocupação do legislador no exercício destas atividades sob o efeito de drogas é tão relevante que justificou a sua tipificação penal no artigo 39 da Lei 11.343/06. ${ }^{226}$

Para esses casos, além da tipificação penal, entendemos que existe um bem de maior relevância e abrangência capaz de justificar a limitação da privacidade do trabalhador.

Acolhidas as razões que autorizam a realização destes exames, destacamos que em razão do princípio da boa-fé que deve permear as relações laborais, a submissão do empregado a testes toxicológicos na hipótese acima ventilada não deverá ser realizada de forma periódica ou indiscriminada, mas apenas nas situações em que houver fortes indícios

\footnotetext{
${ }^{226}$ Art. 39. Conduzir embarcação ou aeronave após o consumo de drogas, expondo a dano potencial a incolumidade de outrem:

Pena - detenção, de 6 (seis) meses a 3 (três) anos, além da apreensão do veículo, cassação da habilitação respectiva ou proibição de obtê-la, pelo mesmo prazo da pena privativa de liberdade aplicada, e pagamento de 200 (duzentos) a 400 (quatrocentos) dias-multa.

Parágrafo único. As penas de prisão e multa, aplicadas cumulativamente com as demais, serão de 4 (quatro) a 6 (seis) anos e de 400 (quatrocentos) a 600 (seiscentos) dias-multa, se o veículo referido no caput deste artigo for de transporte coletivo de passageiros.
} 
de que o empregado está praticando atos capazes de colocar em risco a vida ou a saúde de terceiros. A imposição desta condição visa garantir a maior preservação possível ao direito personalíssimo do trabalhador.

\subsubsection{Testes e exames genéticos}

Os testes e exames genéticos consistem na identificação e mapeamento de todo o material biológico que determina a carga genética existente em cada pessoa, sendo capaz de identificar genes que causam doenças ou que contribuem para o seu aparecimento.

A primeira questão que se coloca sobre os testes genéticos é se estes devem ser considerados como mais um instrumento para obter informações sobre o estado de saúde da pessoa ou se devem ser considerados como algo extraordinário, porquanto isto constitui uma intervenção extremamente profunda na esfera da personalidade do examinado.

Apesar da novidade que aparenta existir na discussão sobre a licitude dos exames de DNA realizados em trabalhadores e candidatos ao emprego, Julio Manuel Vieira Gomes destaca que em 1989 já havia discussão na doutrina alemã ${ }^{227}$ sobre a matéria. Mesmo não sendo um tema muito recente, certo é que com a evolução tecnológica e com o aperfeiçoamento destes testes, a discussão sobre a matéria ganha maior relevância e atualidade.

Os que defendem os testes genéticos destacam as suas vantagens científicas e terapêuticas, sob o argumento de que possuem uma aplicação essencialmente preventiva, evitando que o empregado se exponha a determinadas substâncias ou desenvolva determinadas atividades que, aliadas a sua predisposição genética, poderão ser nocivas a sua saúde. Ainda, sustentam que os testes beneficiam o próprio trabalhador examinado, proporcionando-lhe uma valiosa informação sobre as suas suscetibilidades genéticas, possibilitando que trabalhe em um ambiente menos danoso para a sua saúde. E, por fim, argumentam que em alguns postos de trabalho muito sensíveis, os testes genéticos seriam importantes para resguardar a segurança do próprio trabalhador e de terceiros.

\footnotetext{
${ }^{227} \mathrm{O}$ autor cita as obras de Erwin Deutsch, Die Genomanalyse im Arbeits - und Sozialrecht - Ein Beitrag zum genetischen Datenschutz, NZA, 1989, p. 657 e segs. e Günther Wiese, Genetische Analyse bei Arbeitenehemern, RdA, 1986, p. 120 e segs. In: GOMES, Júlio Manuel Vieira. op. cit., v. 1, p. 345.
} 
Os que sustentam a ilegitimidade dos testes genéticos contra-atacam argumentando que este exame, além de afrontar integralmente a privacidade obreira, acarreta na discriminação e na segregação dos trabalhadores.

Os exames de DNA são instrumentos poderosos, pois através deles é possível verificar o genoma completo não apenas do indivíduo em causa, mas de todos os seus familiares próximos. Assim, os testes genéticos representam uma ameaça à privacidade não só da pessoa pesquisada (no caso, em análise, o trabalhador), mas de todos os seus familiares que não possuem qualquer relação com o empregador.

Outro aspecto que distingue os exames comuns dos testes genéticos consiste no fato de os primeiros não analisarem o estado de saúde da pessoa, mas sim a sua predisposição genética. Julio Manuel Vieira Gomes, utilizando a análise feita por Günter Wiese, pondera que os exames genéticos estão estritamente ligados à personalidade da pessoa submetida ao teste, visto que um dado genético não é uma mera informação sobre a presumível aptidão do trabalhador para determinada tarefa, mas constitui antes uma informação sobre um elemento essencial da sua personalidade, uma predisposição que faz parte, por assim dizer, do seu destino. ${ }^{228}$

Além disso, os resultados obtidos através dos testes são totalmente especulativos, pois somente indicam a probabilidade do desenvolvimento de determinada doença que, na realidade, pode efetivamente não se desenvolver. Assim, mesmo que utilizado para salvaguardar a saúde do empregado - em razão do risco da atividade, por exemplo questiona-se a legitimidade destes exames, em razão de a mera probabilidade de desenvolver a doença acabar por estigmatizar o trabalhador, criando uma discriminação genética. $^{229}$

Outro risco destacado por Julio Manuel Vieira Gomes, com quem concordamos, diz respeito à utilização dos testes genéticos, sob o argumento de determinar quais os trabalhadores são mais suscetíveis a determinadas doenças ou vulneráveis a certos riscos; na realidade, fazer uma utilização inversa, ou seja, para tentar encontrar os trabalhadores mais capazes de resistir, mais tolerantes ao risco. Desta forma, conclui o autor que, ao invés de reduzir a toxidade ou nocividade de determinada substância a que os empregados

\footnotetext{
${ }^{228}$ GOMES, Júlio Manuel Vieira. op. cit., v. 1, p. 350.

${ }^{229}$ Id. Ibid., p. 346.
} 
estão sujeitos, os empregadores tenderiam a perpetuar o uso de agentes tóxicos, selecionando os trabalhadores mais resistentes. ${ }^{230}$

João Nuno Zenha Martins entende que o risco da utilização indevida de testes genéticos não está limitado à fase pré-contratual ou à execução do contrato. $\mathrm{O}$ autor entende ser possível a utilização de exames genéticos em situações de dispensa coletiva eminente, quando o empregador poderá valer-se da averiguação genética para definir quem será e quem não será despedido, dando preferência para a manutenção daqueles com menores propensões genéticas a doenças. ${ }^{231}$ Diante dos avanços da tecnologia e da facilidade com que tais exames vêm sendo aplicados, entendemos que tal risco efetivamente existe.

Em Portugal, a Lei n. 12, de 26 de janeiro de 2005, que dispõe sobre informação genética pessoal e informação de saúde, determina nos itens $1^{\circ}$ e $2^{\circ}$ do artigo $13^{\circ}$ que "a contratação de novos trabalhadores não pode depender de selecção assente no pedido, realização ou resultados prévios de testes genéticos" e "às empresas e outras entidades patronais não é permitido exigir de seus trabalhadores, mesmo que com o seu consentimento, a realização de testes genéticos ou a divulgação de resultados previamente obtidos".

Artigo 13.3 da Lei 12/2005 estabelece que:

\begin{abstract}
nos casos em que o ambiente de trabalho possa colocar riscos específicos para um trabalhador com uma dada doença ou susceptibilidade, ou afectar a sua capacidade de desempenhar com segurança uma dada tarefa, pode ser usada a informação genética relevante para benefício do trabalhador e nunca em seu prejuízo, desde que tenha em vista a protecção da saúde da pessoa, a sua segurança e a dos restantes trabalhadores, que o teste genético seja efectuado após consentimento informado e no seguimento do aconselhamento genético apropriado, que os resultados sejam entregues exclusivamente ao próprio e ainda que não seja nunca posta em causa a sua situação laboral.
\end{abstract}

No entanto, o artigo 13.4 do mesmo dispositivo legal apresenta uma exceção à regra, pois faculta que "as situações particulares que impliquem riscos graves para a segurança ou a saúde pública podem constituir uma excepção ao anteriormente estipulado, observando-se, no entanto, a restrição imposta no número seguinte". De qualquer sorte, o artigo 13.5 da mesma lei apresenta uma condição para a realização do teste, qual seja: "nas

\footnotetext{
${ }^{230}$ GOMES, Júlio Manuel Vieira. op. cit., v. 1, p. 347.

${ }^{231}$ MARTINS, João Nuno Zenha. O genoma humano e a contratação laboral: progresso ou fatalismo? Oeiras: Celta Ed., 2002. p. 17.
} 
situações previstas nos números anteriores os testes genéticos, dirigidos apenas a riscos muito graves e se relevantes para a saúde actual do trabalhador, devem ser seleccionados, oferecidos e supervisionados por uma agência ou entidade independente e não pelo empregador."

Analisando o disposto na Lei 12/2005, Julio Manuel Vieira Gomes, assevera que mesmo o consentimento do candidato (ou trabalhador) só deveria ser relevante face a situações em que a protecção da própria integridade do trabalhador e, sobretudo, de terceiros, justificasse a realização do teste. Aliás, talvez nem mesmo a protecção da integridade do trabalhador pudesse justificá-la já que o que está aqui em jogo é tão-só um perigo potencial e o trabalhador deve poder decidir se assume ou não um determinado risco de cuja existência foi previamente informado pelo empregador $^{232}$.

Após as considerações acima é possível concluir que mesmo considerando a necessidade de proteção de saúde do trabalhador e de terceiros, a realização do teste genético não está autorizada sob qualquer hipótese, em razão da possibilidade da sua utilização indiscriminada e em prejuízo ao empregado. Seja porque a questão genética é de foro extremamente íntimo - desconhecido, inclusive, pelo próprio empregado, seja porque a investigação genética extrapola a verificação da pessoa (se estendendo à vida e ao histórico familiar pregresso e futuro do trabalhador), seja porque em razão de demonstrar apenas uma tendência ao desenvolvimento de doença que sequer poderá ser confirmada não poderá ser considerada como um instrumento a ser utilizado no ambiente de trabalho de forma a preservar um bem maior.

Portanto, entendemos que o teste genético não admite exceção, sendo regra a sua vedação em razão da aplicação dos princípios da dignidade da pessoa humana e garantias fundamentais correlatas. Nesse sentido, não concordamos com a previsão contida na lei portuguesa, pois não conseguimos vislumbrar qualquer hipótese em que o teste genético poderá ser utilizado como um instrumento necessário para a execução do contrato de trabalho.

\footnotetext{
${ }^{232}$ GOMES, Júlio Manuel Vieira. op. cit., v. 1, p. 348.
} 


\subsection{Elaboração de formulários e questionários}

Os formulários e questionários utilizados pelo empregador como meio de obtenção de informações de seus empregados são utilizados atualmente em grande escala pelo empregador, sendo aplicados nas mais diversas fases contratuais. Na fase pré-contratual, são utilizados como um primeiro instrumento de seleção. Durante a execução do contrato, como instrumento de avaliação e feedback. $\mathrm{Na}$ fase de rescisão, é muito frequente a entrevista de dispensa, onde o empregado é questionado sobre vários aspectos da relação que está sendo rescindida naquele momento.

Além da larga aplicação nas diversas fases contratuais, os questionários adentram em matérias cada vez mais amplas, extrapolando, na maioria das vezes, o objeto do contrato de trabalho.

Não há dúvida de que os formulários de entrevistas e o preenchimento de questionários são instrumentos importantes no processo de seleção, manutenção e rescisão do contrato de trabalho. No entanto, a questão que se coloca é até onde o empregador pode ir com a aplicação destes questionários. Isso porque o empregador não tem o direito de adentrar na esfera privada do trabalhador e questionar aquilo que não é necessário para o exercício da função para a qual está se candidatando ou está executando.

Novamente, o raciocínio a ser aplicado é estabelecer o limite do próprio contrato de trabalho, qual seja: o empregador tem o direito - com o respectivo dever do trabalhador de responder às perguntas diretamente relacionadas à vaga ou função a ser desempenhada. Qualquer questionamento que extrapole esse limite será considerado abusivo.

A questão que se coloca diz respeito a quais informações são estritamente necessárias para o desempenho da função. Entendemos que raça, religião, condição social, convicções políticas, vida familiar ou afetiva, etc., são informações desnecessárias para o exercício da função. Sexo poderá ser uma informação importante caso a vaga oferecida necessite de alguma proteção especial para a mulher.

A apresentação de questionários com perguntas desta natureza pelo empregador, além de afrontar a privacidade do trabalhador, poderá ser utilizada como uma ferramenta de discriminação, pois categorias de empregados poderão ser excluídas já no início do processo de seleção. Na França, por exemplo, atualmente, constata-se um grande problema com relação aos questionários que solicitam a indicação da nacionalidade dos 
trabalhadores, em razão do atual problema de discriminação racial na Europa e, especialmente, na França.

O artigo L-121-7 do Code du Travail francês obriga o empregador, sob controle do Comitè d'entreprise (L-432-2-1), a informar previamente o candidato dos meios, métodos, técnicas auxiliares ao recrutamento que vai utilizar, sendo que estes devem ser proporcionais e adequados ao escopo pretendido. Por sua vez, o artigo L-121-6 estabelece que o empregador somente pode questionar o candidato sobre assuntos que tenham conexão direta e necessária com a vaga colocada à disposição, e cujo objetivo seja o de apreciar a sua aptidão profissional e a sua capacidade para ocupar o posto de trabalho. Sobre os artigos em questão, Julio Manuel Vieira Gomes concorda com a disposição francesa, sob pena de, de outro modo, se permitir uma agressão extremamente intensa a aspectos da personalidade e da privacidade do trabalhador. ${ }^{233}$

Sobre os limites estipulados pela doutrina francesa para os questionários e documentos pré-contratuais solicitados pelo empregador, Julio Manuel Vieira Gomes comenta o entendimento firmado no sentido de que o empregador está autorizado a solicitar ao candidato o certificado de escolaridade e os diplomas que ele obteve ou a demonstração de uma experiência profissional que pretende ter tido. No entanto, é vedado ao empregador questionar aspectos sobre o estado de saúde, a vida sexual, o domicílio, a profissão dos pais e/ou cônjuge ou o modo como o trabalhador ocupa o seu tempo livre. ${ }^{234}$

$\mathrm{O}$ artigo $8^{\circ}$ do Estatuto dei Lavoratori da Itália proíbe, para fins de recrutamento ou de pesquisa durante o contrato de trabalho, o questionamento ou a investigação, mesmo que através de terceiros, da opinião política, religiosa ou sindical dos trabalhadores, por entender que estes são irrelevantes para a avaliação da competência profissional do empregado.

O Código do Trabalho de Portugal, além de definir, expressamente no artigo $16.2^{235}$, que as informações referentes à vida familiar e sexual, o estado de saúde e as convicções políticas e religiosas são protegidas pela reserva da vida privada, também

\footnotetext{
${ }^{233}$ GOMES, Júlio Manuel Vieira. op. cit., v. 1, p. 342.

${ }^{234}$ Id. Ibid., p. 343.

${ }^{235}$ Artigo 16. - Reserva da intimidade da vida privada

1 - O empregador e o trabalhador devem respeitar os direitos de personalidade da contraparte, cabendo lhes,designadamente, guardar reserva quanto à intimidade da vida privada.

2 - $\mathrm{O}$ direito à reserva da intimidade da vida privada abrange quer o acesso, quer a divulgação de aspectos atinentes à esfera íntima e pessoal das partes, nomeadamente relacionados com a vida familiar, afectiva e sexual, com o estado de saúde e com as convicções políticas e religiosas.
} 
impede, no seu artigo $17.1^{236}$, que o empregador exija a candidato a emprego ou a trabalhador que preste informações relativas à sua vida privada, exceto quando estas forem necessárias e relevantes para a avaliação da respectiva aptidão para o trabalho, devendo o empregador apresentar por escrito a justificativa para tal questionamento.

A previsão do artigo 17.1 do Código do Trabalho de Portugal nos parece acertada, pois questões relacionadas com a experiência profissional do trabalhador, suas habilitações ou endereço de seu domicílio, por exemplo, não integram a esfera privada, sendo relevantes para a execução do contrato de trabalho. Portanto, poderão ser questionadas pelo empregador.

As disposições legais dos países europeus citados estão em consonância com a Diretiva 95/46/CE do Parlamento Europeu e do Conselho, publicada em 24 de outubro de 1995, na qual o Estados-membros deverão proibir a coleta e a manutenção de dados pessoais que revelem a origem racial ou étnica, as opiniões políticas, as convicções religiosas ou filosóficas, a filiação sindical, bem como dados relativos à saúde ou à vida sexual. A Diretiva estabelece exceções à regra, admitindo o questionamento e o arquivamento de informações de natureza privada quando o titular do direito tiver dado o seu consentimento explícito, salvo se a legislação do Estado-membro proibir esse ato de vontade; ou quando o questionamento for necessário para o cumprimento das obrigações e dos direitos decorrentes do contrato de trabalho, desde que este seja autorizado por legislação nacional que estabeleça garantias adequadas; ou quando o questionamento for necessário para proteger interesses vitais da pessoa ou de terceiros, dentre outras exceções. ${ }^{237}$

\footnotetext{
${ }^{236}$ Artigo $17^{\circ}$ - Protecção de dados pessoais

1 - O empregador não pode exigir a candidato a emprego ou a trabalhador que preste informações relativas:

a) À sua vida privada, salvo quando estas sejam estritamente necessárias e relevantes para avaliar da respectiva aptidão no que respeita à execução do contrato de trabalho e seja fornecida por escrito a respectiva fundamentação;

b) À sua saúde ou estado de gravidez, salvo quando particulares exigências inerentes à natureza da actividade profissional o justifiquem e seja fornecida por escrito a respectiva fundamentação.

2- As informações previstas na alínea b) do número anterior são prestadas a médico, que só pode comunicar ao empregador se o trabalhador está ou não apto a desempenhar a actividade.

3 - O candidato a emprego ou o trabalhador que haja fornecido informações de índole pessoal goza do direito ao controlo dos respectivos dados pessoais, podendo tomar conhecimento do seu teor e dos fins a que se destinam, bem como exigir a sua rectificação e actualização.

4 - Os ficheiros e acessos informáticos utilizados pelo empregador para tratamento de dados pessoais do candidato a emprego ou trabalhador ficam sujeitos à legislação em vigor relativa à protecção de dados pessoais.

5 - Constitui contra -ordenação muito grave a violação do disposto nos n.os 1 ou 2.

${ }^{237}$ Artigo $8^{\circ}$ - Tratamento de certas categorias específicas de dados

1. Os Estados-membros proibirão o tratamento de dados pessoais que revelem a origem racial ou étnica, as opiniões políticas, as convicções religiosas ou filosóficas, a filiação sindical, bem como o tratamento de dados relativos à saúde ou à vida sexual.
} 
Apesar da omissão do legislador trabalhista, tomamos como inspiração a Diretiva da União Europeia citada acima para sustentar que as perguntas formuladas em questionários pré, durante e pós-contratuais devem estar limitadas às matérias necessárias para a verificação da aptidão ou inaptidão para o trabalho. Qualquer questionamento que extrapole esse limite será considerado abusivo.

Quando o questionamento para o desempenho da função tiver que, de forma imprescindível, abranger aspectos da vida privada do trabalhador, a intromissão nessa esfera de resguardo do indivíduo somente pode ocorrer se justificada por escrito pelo empregador e contar com a autorização do empregado e a anuência do sindicato. Essas precauções são necessárias para garantir o núcleo essencial da privacidade do trabalhador.

2. $\mathrm{O} \mathrm{n}^{\circ} 1$ não se aplica quando: a) A pessoa em causa tiver dado o seu consentimento explícito para esse tratamento, salvo se a legislação do Estado-membro estabelecer que a proibição referida no ${ }^{\circ} 1$ não pode ser retirada pelo consentimento da pessoa em causa; ou b) O tratamento for necessário para o cumprimento das obrigações e dos direitos do responsável pelo tratamento no domínio da legislação do trabalho, desde que o mesmo seja autorizado por legislação nacional que estabeleça garantias adequadas; ou c) $\mathrm{O}$ tratamento for necessário para proteger interesses vitais de pessoa em causa ou de uma outra pessoa se a pessoa em causa estiver física ou legalmente incapaz de dar o seu consentimento; ou d) O tratamento for efectuado, no âmbito das suas actividades legítimas e com as garantias adequadas, por uma fundação, uma associação ou qualquer outro organismo sem fins lucrativos de carácter político, filosófico, religioso ou sindical, na condição de o tratamento dizer unicamente respeito aos membros desse organismo ou às pessoas que com ele mantenham contactos periódicos ligados às suas finalidades, e de os dados não serem comunicados a terceiros sem o consentimento das pessoas em causa; ou e) $\mathrm{O}$ tratamento disser respeito a dados manifestamente tornados públicos pela pessoa em causa ou for necessário à declaração, ao exercício ou à defesa de um direito num processo judicial.

3. $\mathrm{O} \mathrm{n}^{\circ} 1$ não se aplica quando o tratamento dos dados for necessário para efeitos de medicina preventiva, diagnóstico médico, prestação de cuidados ou tratamentos médicos ou gestão de serviços da saúde e quando o tratamento desses dados for efectuado por um profissional de saúde obrigado ao segredo profissional pelo direito nacional ou por regras estabelecidas pelos organismos nacionais competentes, ou por outra pessoa igualmente sujeita a uma obrigação de segredo equivalente.

4. Sob reserva de serem prestadas as garantias adequadas, os Estados-membros poderão estabelecer, por motivos de interesse público importante, outras derrogações para além das previstas no $n^{\circ} 2$, quer através de disposições legislativas nacionais, quer por decisão da autoridade de controlo referida no artigo $28^{\circ}$.

5. O tratamento de dados relativos a infracções, condenações penais ou medidas de segurança só poderá ser efectuado sob o controlo das autoridades públicas ou se o direito nacional estabelecer garantias adequadas e específicas, sob reserva das derrogações que poderão ser concedidas pelo Estado-membro com base em disposições nacionais que prevejam garantias específicas e adequadas. Contudo, o registo completo das condenações penais só pode ser mantido sob o controlo das autoridades públicas.

Os Estados-membros podem estabelecer que o tratamento de dados relativos a sanções administrativas ou decisões cíveis fique igualmente sujeito ao controlo das autoridades públicas.

6. As derrogações ao $n^{\circ} 1$ previstas nos $n^{\circ} 4$ e 5 serão notificadas à Comissão.

7. Cabe aos Estados-membros determinar as condições em que um número nacional de identificação ou qualquer outro elemento de identificação de aplicação geral poderá ser objecto de tratamento. 


\subsection{Direito de omitir informações em entrevista, questionário ou exame}

Conforme esclarecido, empregado e empregador têm o dever recíproco de informação e lealdade. Pelo dever de informação, as partes devem trocar todos os elementos necessários ou úteis para a formação, execução e, até mesmo, extinção do contrato. Por sua vez, o dever de lealdade obriga as partes a prevenir qualquer comportamento capaz de afrontar a confiança ou a primazia da materialidade subjacente, onde a norma deve buscar prescrever saídas e soluções efetivas e não meramente formais. ${ }^{238} \mathrm{O}$ dever de informação, que decorre do princípio geral da boa-fé, é necessário para a formação e manutenção do contrato de trabalho.

No entanto, o dever de prestação de informações pessoais por parte do empregado está adstrito ao mínimo necessário para o atendimento do próprio contrato de trabalho, principalmente quando estas informações forem capazes de violar direitos fundamentais. Segundo Antonio Menezes Cordeiro, ninguém é, em princípio, obrigado a contar fatos "infamantes" que não tenham uma absoluta relação objetiva com o trabalho a prestar. Já o trabalhador no curso do contrato de trabalho não tem o dever de revelar esse fato, salvo se a natureza das funções assim justificar. Informações sobre o estado clínico ou sobre anteriores doenças do trabalho só são requeridas quando objetivamente relevantes para o desempenho da atividade ou em razão de perigo que essa atividade possa causar ao trabalhador ou a terceiros. ${ }^{239}$

Desta forma, se o questionamento formulado pelo empregador extrapolar o limite necessário para a execução do próprio trabalho e, portanto, invadir indevidamente a sua privacidade, entendemos que o empregado está autorizado a não responder a esses questionamentos.

Se o empregador questionar aspectos que não têm relação com o emprego ou a atividade a ser desempenhada ou atualmente desenvolvida, o trabalhador tem a faculdade de mentir ou de se calar. A faculdade de mentir não é um "direito geral de mentira", mas um "direito" particular em razão da matéria proibida sobre a qual incide a questão. ${ }^{240}$

O empregado tem o direito de omitir informações, mesmo quando essa omissão representar um risco à sua saúde. A obrigação de informação é do empregador, que deve

\footnotetext{
${ }^{238}$ CORDEIRO, Antonio Menezes. Manual de direito do trabalho. Coimbra: Almedina, 1991. p. 557-558.

${ }^{239}$ Id. Ibid., p. 560-561.

${ }^{240}$ GOMES, Júlio Manuel Vieira. op. cit., v. 1, p. 343.
} 
apontar os riscos da atividade, sendo que se o empregado não manifestar qualquer fato prejudicial a sua saúde ou que possa agravar eventual enfermidade, entende-se que ele assumiu esse risco.

Nesta hipótese, se o empregado omitir informações a respeito da sua condição e sofrer algum dano em razão do risco causado pela atividade desenvolvida é possível sustentar que, por mais que exista responsabilidade objetiva do empregador, este não pode ser responsabilizado por este dano, em razão de o trabalhador não ter prestado as informações necessárias sobre a sua condição, capazes de reduzir ou eliminar o risco da função. O empregado, nesse caso, assumiu o risco.

A assunção desta responsabilidade por parte do empregado ocorre apenas quando é demonstrado, de forma inequívoca, que o empregador informou, no ato da contratação ou quando da alteração da função, sobre os riscos inerentes à função. $\mathrm{O}$ empregador cumpriu com o seu dever de informar sobre os riscos inerentes à atividade. Contudo, se o empregado resguardou o seu direito de omitir a sua condição de saúde, não poderá responsabilizar o empregador no futuro, caso sofra algum dano por ter ficado exposto a este risco em uma situação de maior vulnerabilidade.

Se o empregado tem direito de omitir informações sobre a sua vida pessoal não relacionadas com o trabalho, esse direito de omissão é ainda mais acentuado quando a pergunta apresentada diz respeito sobre o estado de gravidez da empregada. Conforme visto acima, o questionamento ou imposição para a realização de exame, além de afrontar a privacidade de trabalhadora, constitui prática discriminatória. Desta forma, entendemos que a trabalhadora tem garantido integralmente o seu direito de omissão.

Aspecto interessante a ser analisado diz respeito ao direito da empregada em ocultar o seu estado gravídico quando exercer ou estiver se candidatando ao exercício de atividade nociva para a sua saúde e para a do feto.

O tratamento desse tema em Portugal foi sendo desenvolvido ao longo do tempo, visto que o primeiro entendimento foi no sentido de que se a mulher grávida pretendesse celebrar um contrato deveria, sempre, esclarecer esse fato para o empregador. Depois, passou-se a entender que esse dever era discriminatório, sendo que a obrigação de informar a gravidez somente ocorreria quando se tratasse de preencher lugares em que concorressem 
apenas mulheres. Atualmente, entende-se que a exigência de informação sobre gravidez é inadmissível, pois atenta contra a esfera da intimidade da trabalhadora. ${ }^{241}$

Pela disposição atual do Código do Trabalho português, a empregada não tem obrigação de prestar informação sobre a sua gravidez, sendo do empregador a obrigação de advertir a empregada sobre eventual perigo ou nocividade da função para a grávida, cabendo à empregada decidir se irá exercer ou não essa função. Segundo Julio Manuel Viera Gomes

os deveres do empregador de avaliar a natureza, grau e duração da exposição da trabalhadora grávida a riscos para a sua segurança e saúde, bem como tomar as medidas necessárias para evitar a exposição da trabalhadora a esses riscos, ficam dependentes da apresentação pela própria trabalhadora de atestado médico que comprove o estado de gestação (...) embora nos pareça que tais deveres já se deverão afirmar se a gestação for um facto notório, mesmo que a trabalhadora, por hipótese, não tenha apresentado qualquer atestado médico. ${ }^{242}$

A legislação brasileira, em especial as disposições que impedem a realização ou questionamentos sobre o estado gravídico da empregada, nos leva à conclusão de que a candidata ao emprego tem plena possibilidade de ocultar a sua gravidez, sendo que tal omissão não importa em violação ao princípio da boa-fé, já que esta informação encontrase resguardada no âmbito da intimidade da empregada. ${ }^{243}$

Contudo, entendemos existir exceção a essa regra nas hipóteses em que a gravidez constituir obstáculo ao exercício das funções e realização das tarefas, situação na qual a mulher não pode ocultar a sua condição, como é o caso do trabalho em usinas nucleares ou clínicas radiológicas, uma vez que em tais situações a exposição à radiação poderá causar a malformação do feto. ${ }^{244}$

Trata-se de um típico exemplo de limitação da privacidade decorrente do exercício do próprio contrato e, mais, que visa resguardar a saúde da trabalhadora e, principalmente, do bebê. Nesse caso, o dever de informação deve ser imposto em casos muito extremos, que envolvam radiação ou contato com produtos que possam acarretar a malformação do feto.

${ }^{241}$ CORDEIRO, Antonio Menezes. op. cit., p. 561.

${ }^{242}$ GOMES, Júlio Manuel Vieira. op. cit., v. 1, p. 351.

${ }^{243}$ OLIVEIRA, Paulo Eduardo Vieira de. A privacidade da pessoa humana no ambiente de trabalho, cit., p. 174.

${ }^{244}$ Id. $O$ dano pessoal no direito do trabalho, cit., p. 102. 
Por esse raciocínio, a realização de teste de gravidez como pressuposto para a contratação de trabalhadoras é defensável, pois nos casos em que a própria empregada desconhece o seu estado gravídico, não parece ser razoável prejudicar a formação do feto e comprometer-lhe toda a sua futura vida - pela exposição indevida da grávida a radiações, pelo simples fato de desconhecer o seu estado gravídico.

\subsection{Tratamento de dados do empregado}

Durante todas as fases contratuais, o empregador tem acesso a dados importantes do empregado (para citar alguns exemplos, informações referentes ao processo de seleção, ao processo de avaliação e promoção, e a dados referentes à rescisão, sons, imagens), sendo que todos esses dados pessoais, sejam eles privados ou não, merecem ser tratados de forma cuidadosa.

Consideram-se dados pessoais quaisquer informações referentes a uma pessoa singular relativa à sua identidade física, fisiológica, psíquica, econômica, cultural ou social. $^{245}$

No tratamento de dados pessoais, os desdobramentos da privacidade vão além dos limites da sua própria definição, pois na medida em que a privacidade do indivíduo é violada para coletar informações sobre a pessoa, esta poderá ser julgada por esses dados coletados, o que poderá acarretar na perda de parte da sua autonomia, individualidade e liberdade. Na sociedade moderna da informação, a afronta à privacidade não está exclusivamente relacionada aos meios "clássicos" de invasão, tais como intrusão na habitação, divulgação de notícias na imprensa ou violação de correspondência, mas se dá com maior frequência através da divulgação de dados pessoais ${ }^{246}$

A exposição cada vez maior de dados pessoais do indivíduo em sites de relacionamento e redes sociais (Orkut, Facebook, Twitter, etc.) justifica a preocupação com o tratamento que deve ser conferido aos dados do empregado que o empregador tem acesso.

\footnotetext{
${ }^{245}$ A definição de dados pessoais foi extraída do artigo 2.1.a da Diretiva 95/46/CE.

${ }^{246}$ DONEDA, Danilo. Da privacidade à proteção de dados pessoais, cit., p. 1-2.
} 
Nesse sentido, a preocupação com o tratamento patronal aos dados pessoais do empregado representa a nova face do direito ao resguardo. Para Danilo Doneda, a proteção de dados nada mais é do que a evolução do direito à privacidade. ${ }^{247}$

A União Europeia demonstrou a sua preocupação com o tratamento de dados do cidadão e, consequentemente, do empregado ${ }^{248}$. A mais representativa Diretiva para a finalidade do presente trabalho é a de número 46, do ano de 1995 (95/46/CE), que tem como objetivo assegurar a proteção das liberdades e dos direitos fundamentais dos cidadãos europeus, especialmente do direito à vida privada, e quanto ao tratamento de dados pessoais, tendo influenciado o tratamento dessa matéria pelo ordenamento interno dos Estados integrantes da União Europeia.

A Diretiva instituiu as principais diretrizes para o tratamento de dados pessoais no âmbito geral, determinando a obrigação dos Estados-membros de estabelecer dentro do ordenamento interno o tratamento legal e lícito dos dados pessoais, impondo que o recolhimento destes dados deve ser realizado com finalidades determinadas, explícitas e legítimas, através de instrumentos adequados, pertinentes e não excessivos, devendo ser mantidos de forma a permitir a identificação da pessoa em causa apenas durante o período necessário à consecução das finalidades às quais foram coletados.

A coleta e a manutenção de dados pessoais são autorizadas pela Diretiva mediante as seguintes condições: i) consentimento inequívoco do titular do direito, estabelecendo que o tratamento de dados deve ocorrer somente quando for necessário para a execução de um contrato no qual a pessoa em causa é parte ou para a realização de diligências prévias à formação do contrato; ii) o tratamento for necessário para cumprir uma obrigação legal à qual o responsável pelo tratamento esteja sujeito; iii) o tratamento for necessário para a proteção de interesses vitais da pessoa em causa; iv) o tratamento for necessário para a execução de uma missão de interesse público ou o exercício da autoridade pública de que é investido o responsável pelo tratamento ou um terceiro a quem os dados sejam comunicados; ou v) o tratamento for necessário para a defesa de interesses legítimos do

\footnotetext{
${ }^{247}$ DONEDA, Danilo. Da privacidade à proteção de dados pessoais, cit., p. 1.

${ }^{248}$ Sobre tratamento de dados, indicamos a Diretiva 95/46/CE, do Parlamento Europeu e do Conselho, de 24 de outubro de 2005, sobre proteção das pessoas singulares no que respeita ao tratamento de dados pessoais e à livre circulação desses dados; Diretiva 97/66/CE, do Parlamento Europeu e do Conselho, de 15 de dezembro de 1997, sobre o tratamento de dados pessoais e proteção da privacidade no setor das telecomunicações; Diretiva 2000/31CE, de 8 de junho de 2000, sobre comércio eletrônico; Diretiva 2002/58/CE, do Parlamento Europeu e do Conselho, sobre tratamento de dados pessoais e proteção da privacidade no setor das comunicações eletrônicas; e Diretiva 2006/24/CE, de 15 de março de 2006, sobre a conservação de dados das comunicações eletrônicas e alteração da Diretiva 2002/58/CE.
} 
responsável pela coleta de dados ou de terceiros a quem os dados sejam comunicados, desde que não prevaleçam os interesses ou os direitos e liberdades fundamentais da pessoa em causa. $^{249}$

As obrigações determinadas pela Diretiva foram transpostas aos ordenamentos internos dos Estados-membros. Na Espanha, citamos a Lei Orgânica 15/1999 de Proteção de Dados de Caráter Pessoal (LOPD). Na Itália, temos o Decreto Legislativo n. 276/2003 (que regulamentou a Lei 30/2003, conhecida como Legge Biaggi), que possui disciplina sobre a privacidade no recrutamento e seleção do candidato ao emprego. $\mathrm{O}$ artigo $8^{\circ}$ deste Decreto determina que no processo de recrutamento e seleção o empregado tem o direito de indicar as pessoas ou a classe de pessoas a quem os seus dados podem ser compartilhados. Ainda na Itália, o artigo 111 do Decreto Legislativo 196/2003 (Codice della privacy) dispõe sobre a coleta e processamento de informações de empregados, recomendando que o empregador adote um código de ética e boa conduta dispondo sobre o tratamento de dados pessoais e sensíveis do trabalhador.

As disposições do Código de Portugal sobre o tratamento de dados pessoais do trabalhador podem talvez ser consideradas como as mais completas e detalhadas dos Estados-membros da União Europeia. Segundo Maria Regina Redinha ${ }^{250}$, o Código do Trabalho português, ao dispor sobre a proteção de dados pessoais, além de ter como matriz a Diretiva da UE, realizou uma transposição da regulamentação geral da matéria constante na Lei n. 97/98, de 26 de outubro, nomeadamente no que se refere ao acesso, controle e conhecimento da finalidade da solicitação e/ou do tratamento. Da leitura do tratamento conferido pelo Código do Trabalho sobre a matéria também é possível observar referências às leis 41/2004, de 18 de agosto (tratamento de dados pessoais e proteção da privacidade no setor das comunicações eletrônicas) e 12/2005, de 26 de janeiro, (informação genética pessoal e informação de saúde).

O artigo 17 do Código do Trabalho de Portugal, conforme esclarecido anteriormente, estabelece a proteção a dados pessoais do empregado, impedindo o empregador de exigir informações sobre a vida privada do trabalhador, salvo quando estas foram estritamente necessárias e relevantes para avaliar a aptidão para o trabalho.

\footnotetext{
${ }^{249}$ Esta é a redação do artigo $7^{\circ}$ da Diretiva 95/46/CE. COMUNIDADE EUROPEIA. Diretiva 95/46/CE do Parlamento Europeu e do Conselho de 24 de outubro de 1995. Relativa à protecção das pessoas singulares no que diz respeito ao tratamento de dados pessoais e à livre circulação desses dados. Disponível em: $<$ http://www.umic.pt/images/stories/publicacoes200709/Directiva95_46_CE.pdf>. Acesso em: $02 \mathrm{dez}$. 2010.

${ }^{250}$ REDINHA, Maria Regina. Direitos de personalidade, cit., p. 5 .
} 
A previsão da legislação trabalhista portuguesa impõe que caso o empregado ou candidato ao emprego forneça informações de índole pessoal, deve lhe ser garantido o controle destes dados, podendo tomar conhecimento do seu teor e dos fins a que se destinam, bem como exigir a sua retificação ou atualização. O legislador português também determina que os arquivos e meios eletrônicos e de informática utilizados pelo empregador para o tratamento de dados pessoais do trabalhador ou candidato à vaga de emprego ficam sujeitos ao tratamento especial conferido por lei.

No Brasil, não constatamos o mesmo cuidado que teve o legislador europeu. De qualquer forma, entendemos que os deveres de proteção, boa-fé e informação que permeiam o contrato de trabalho obrigam o empregador a tratar dignamente os dados pessoais do empregado. As informações pessoais coletadas em processo seletivo, durante a execução do contrato ou em entrevista demissional não podem ser divulgadas pelo empregador para colegas de trabalho (exceto àqueles cujas informações são relevantes para a avaliação do empregado) ou para terceiros.

Os dados pessoais devem ser arquivados de forma a garantir o sigilo dessas informações e somente devem ser mantidos nos arquivos do empregador durante o período de execução do contrato de trabalho. Tendo em vista que a coleta de dados pessoais se dá em razão da execução do próprio contrato de trabalho, não nos parece razoável sustentar a manutenção destes dados mesmo após o término da relação empregatícia.

Aspecto interessante a ser analisado diz respeito ao tratamento dos dados pessoais do trabalhador a que o empregador tem acesso, não por questionamento direto, mas por consulta a sites de relacionamento ou redes sociais da internet.

Em princípio, considerando que as informações pessoais não devem interessar para a execução do contrato de trabalho (salvo situações específicas, como a do vigilante, conforme visto no capítulo 3), o empregador sequer estaria legitimado a averiguar páginas de internet ou de redes sociais para buscar informações sobre o trabalhador. Entretanto, não há como sustentar um efetivo direito à privacidade do empregador quando o próprio titular do direito personalíssimo torna público os seus dados pessoais através da sua divulgação na rede mundial de computadores. Uma vez os dados pessoais incluídos em sites de relacionamento ou redes sociais pelo empregado, estes se tornam públicos, facultando-se o acesso a qualquer um, inclusive o empregador. 
Não há, portanto, como sustentar que o empregador está impedido de acessar sites de relacionamento e redes sociais para buscar informações pessoais que foram tornadas públicas pelo próprio empregado. O que não se admite, contudo, é que essas informações de caráter pessoal sejam utilizadas para influenciar o modo pelo qual o empregado é visto ou tratado no seu ambiente de trabalho (até mesmo porque estas não têm qualquer relação com a execução do serviço), sendo vedada a adoção de qualquer atitude patronal discriminatória que vise impedir o desenvolvimento do trabalhador em razão das suas convicções pessoais.

\subsection{Controle de dados biométricos}

A captação de dados biométricos e a sua utilização para identificação e controle do trabalhador também merece ser analisada no presente trabalho, em razão do seu potencial de afronta a um dos bens de maior importância para o trabalhador, que representa a sua própria identidade.

Por dados biométricos se entendem as características físicas ou comportamentais mensuráveis, utilizadas para a verificação de uma identidade. São os dados biológicos que abrangem a impressão digital, a íris, a geometria da mão ou a geometria facial e que constituem, em princípio, características únicas de cada pessoa e permitem, assim, a sua identificação.

O controle laboral através de dados biométricos é uma realidade cada vez mais presente, pois, não é raro encontrar empresas que controlam a jornada de trabalho de seus empregados através da coleta da impressão digital.

O Código do Trabalho de Portugal foi pioneiro ao dispor, na sua redação de 2009, sobre o tratamento dos dados biométricos na relação de emprego. O artigo 18 do Código, na sua redação de $2009,,^{251}$ não trata da fiscalização do trabalho através de dados

\footnotetext{
${ }^{251}$ Dados biométricos

1 - O empregador só pode tratar dados biométricos do trabalhador após notificação à Comissão Nacional de Protecção de Dados.

2 - O tratamento de dados biométricos só é permitido se os dados a utilizar forem necessários, adequados e proporcionais aos objectivos a atingir.

3 - Os dados biométricos são conservados durante o período necessário para a prossecução das finalidades do tratamento a que se destinam, devendo ser destruídos no momento da transferência do trabalhador para outro local de trabalho ou da cessação do contrato de trabalho.
} 
biométricos, mas impõe uma limitação ao tratamento destes dados, tendo sido influenciado pela Diretiva 95/46/CE.

Pela previsão do artigo 18 do Código do Trabalho português, o empregador somente pode proceder ao recolhimento e tratamento de dados biométricos dos trabalhadores se os seus objetivos forem legítimos e os dados forem necessários, adequados e proporcionais à realização desses objetivos. Além disso, o empregador deve notificar previamente a Comissão Nacional de Proteção de Dados - CNPD ${ }^{252}$ de que vai instalar um sistema biométrico, e esta notificação deverá ser acompanhada do parecer prévio da Comissão de Trabalhadores. Além disso, os dados biométricos só podem ser conservados pelo tempo estritamente necessário ao atendimento das finalidades do tratamento e devem ser destruídos quando o trabalhador é transferido para outro local de trabalho ou quando cessa o seu contrato.

No Brasil, por ser um assunto relativamente novo, não há legislação específica cuidando do tratamento de dados biométricos. Mesmo diante da ausência de previsão legal, há necessidade de proteção a estes dados, visto que além de estarem relacionados à privacidade, também dizem respeito à imagem e às partes do corpo do indivíduo.

Por concretizarem mais de um direito da personalidade, entendemos que os dados biométricos somente poderão ser recolhidos em situações especialíssimas, principalmente quando, por questões de segurança, se fizer imprescindível a identificação do trabalhador através dos seus dados personalíssimos.

Diante da ausência de previsão legal no âmbito nacional, a solução dada pelo legislador português quanto ao tratamento de dados biométricos nos parece acertada, pois condiciona a captação e guarda destes somente quando necessária, adequada e proporcional ao objetivo buscado pelo empregador. A autorização para a captação e guarda de dados biométricos se dá, portanto, em razão do próprio contrato de trabalho, quando existir motivo contratual justificável ou quando esse controle é necessário para a garantia de um bem maior, como a vida ou a segurança.

4 - A notificação a que se refere o n. ${ }^{\circ} 1$ deve ser acompanhada de parecer da comissão de trabalhadores ou, não estando este disponível 10 dias após a consulta, de comprovativo do pedido de parecer.

5 - Constitui contra-ordenação grave a violação do disposto no n. ${ }^{\circ} 3$.

${ }^{252}$ A Comissão Nacional de Proteção de Dados é uma entidade administrativa independente com poderes de autoridade, que funciona junto da Assembleia da República. Tem como atribuição controlar e fiscalizar o processamento de dados pessoais, em rigoroso respeito pelos direitos do homem e pelas liberdades e garantias consagradas na Constituição e na lei. 
De igual forma, nos parece acertada a posição do legislador português ao determinar que os dados biométricos do empregado somente poderão ser mantidos durante o período em que perdurar a relação de emprego, devendo ser inutilizados quando da transferência do trabalhador para outro local de trabalho ou quando da rescisão do seu contrato. Considerando que o motivo que justifica a manutenção dos dados biométricos no arquivo do empregador é a existência e a execução do contrato de trabalho, não há que se falar em qualquer motivo legítimo para justificar a guarda destes dados após a cessação da relação de emprego.

Por fim, a necessidade de notificação da Comissão Nacional de Proteção de Dados imposta pela legislação portuguesa também nos parece acertada, pois visa evitar abusos por parte do empregador, equiparando-se à figura do sindicato, como garantidor dos direitos dos empregados, nas premissas indicadas no capítulo 3 do presente trabalho.

\subsection{Sistemas de vigilância presencial e a distância e outras formas de monitoramento}

A fiscalização presencial e ostensiva das atividades do empregado é regulada expressamente por algumas legislações estrangeiras.

Um exemplo é o artigo $2^{\circ}$ do Estatuto de Los Trabajadores da Espanha, que disciplina a contratação de vigias por parte do empregador, onde os profissionais da segurança somente podem ser utilizados para fins de proteção de ativos da empresa, sendo vedado esse serviço para o controle das atividades exercidas pelos empregados. Ainda no âmbito da fiscalização no ambiente de trabalho, o artigo $3^{\circ}$ do Estatuto de Los Trabajadores determina que o empregados devem ser comunicados sobre o nome e a função exercida pelos profissionais responsáveis por fiscalizar as suas atividades.

Ainda quanto à fiscalização direta e presencial, o artigo $2^{\circ}$ do Statuto dei Lavoratori impede o empregador de contratar seguranças com a finalidade específica de fiscalizar as atividades dos trabalhadores, sendo facultada apenas a utilização de seguranças para a proteção de ativos da empresa.

A fiscalização ostensiva no ambiente de trabalho, realizada mediante o emprego de seguranças ou vigias, deve ter como finalidade apenas o resguardo e a segurança dos trabalhadores e de terceiros, não havendo motivo razoável para a utilização deste sistema 
de controle para o acompanhamento das atividades dos empregados, eis que tal prática caracteriza nítido constrangimento aos trabalhadores. É o caso, por exemplo, dos empregados de agências bancárias que estão inseridos em ambiente ostensivamente fiscalizado por seguranças.

A fiscalização a distância é mais perversa, pois o empregado não sabe e sequer tem condições de saber por quem, quando e como está sendo fiscalizado. A fiscalização remota é realizada, geralmente, mediante o emprego de dispositivos tecnológicos para rastrear, monitorar e controlar os indivíduos. Existem vários instrumentos de vigilância eletrônica à disposição do empregador, podendo ser citados, como exemplos, os mecanismos dos automóveis que gravam as distâncias percorridas ou o consumo de combustível, o sistema de posicionamento global por satélite (global positioning system - GPS) e o sistema vídeo eletrônico, sendo este último a espécie mais comum de vigilância eletrônica, realizada mediante a captação de imagens por meio de circuitos internos de televisão integrados a câmeras instaladas em espaços públicos ou privados.

Maria Regina Redinha cita outros sistemas de controle eletrônico a distância, como o software que permite registros quantitativos e descritivos das tarefas realizadas no equipamento utilizado pelo empregado, os programas que registram o tráfico na internet, os sensores de cadeira que registram o tempo em que o trabalhador permanece sentado em seu posto de trabalho ou as placas de identificação dos trabalhadores com chip incorporado, que permitem reconstituir o percurso dos trabalhadores nas instalações da empresa. $^{253}$

A legislação trabalhista nacional nada menciona quanto aos mecanismos de controle eletrônico a distância do trabalhador. A legislação estrangeira, por sua vez, preocupou-se em disciplinar essa matéria no ambiente de trabalho.

O artigo 20 do Estatuto de Los Trabajadores é invocado para disciplinar a utilização de sistemas de vigilância eletrônica no ambiente de trabalho, e determina que o empresário pode adotar medidas que entenda oportunas de vigilância e controle para verificar o cumprimento das obrigações por parte do trabalhador, devendo, no entanto, respeitar a dignidade do empregado.

Já o artigo $4^{\circ}$ do Statuto dei Lavoratori da Itália trata da utilização de equipamentos audiovisuais e de outros equipamentos para monitoramento remoto dos trabalhadores que

\footnotetext{
${ }^{253}$ REDINHA, Maria Regina. Direitos de personalidade, cit.
} 
são facultados somente quando há necessidade organizacional, de produção ou por questão de segurança, desde que previamente negociados com o sindicato.

Na legislação italiana, também merece menção o artigo 114 do Decreto Legislativo 196/2003 (Codice della privacy) que reforça a disposição do artigo $4^{\circ}$ do Statuto dei Lavoratori sobre controle remoto e o artigo 115 que determina que, no âmbito do teletrabalho, o empregado deve ter respeitada a sua privacidade, dispositivo que pode ser invocado para impedir a utilização de instrumentos de monitoramento a distância nessa modalidade de trabalho.

Na Alemanha, segundo Julio Manuel Vieira Gomes, existe doutrina ${ }^{254}$ e jurisprudência defendendo a possibilidade de vigilância por sistemas de vídeo, mesmo oculta e secreta, sob o argumento de que tal prática é único meio efetivo de vigiar os trabalhadores. No entanto, apesar de não ter sido editada lei específica aplicável ao contrato de trabalho, o autor entende que tal posição perdeu força diante do que passou a dispor o parágrafo 6 II BDSG, que proibiu os controles ocultos nos locais de acesso público. Sustenta, entretanto, que esta posição mais permissiva encontrou forte resistência de parte da doutrina ${ }^{255}$ e jurisprudência, que entende que este tipo de controle afronta o direito geral de personalidade do empregado, desumanizando o trabalho, sendo que para a licitude da instalação de câmeras de vigilância faz-se necessária a participação do conselho da empresa, devendo haver proporcionalidade e adequação na utilização dos sistemas de vigilância. No mais, esclarece que a doutrina dominante na Alemanha entende que a instalação de meios de controle audiovisuais somente pode se justificar quando visar a proteção da vida ou da integridade do próprio trabalhador ou de terceiros. ${ }^{256}$

Em Portugal, o artigo $20^{\circ}$ do Código do Trabalho ${ }^{257}$ protege o empregado contra a utilização de meios de vigilância remoto com a finalidade exclusiva de controle do

\footnotetext{
${ }^{254} \mathrm{O}$ autor cita Johannes Röckl e Christian Fahl, Kündingung nach heimlicher Videoüberwanchung, NZA, 1988, p. 1035 e segs. In GOMES, Júlio Manuel Vieira. op. cit., v. 1, p. 327.

${ }^{255} \mathrm{O}$ autor cita, como exemplo, Marie-Theres Tinnefeld e Hans-Peter Viethen, Das Recht AM eigenen Bild als besondere Form des allgemeinen Persönlichkeitsrechts, Grundgendanken um spezielle Fragen des Arbeitnehemerdatenschutzes, NZA, 2003, p. 468 e segs. In: GOMES, Júlio Manuel Vieira. op. cit., v. 1, p. 328.

${ }^{256}$ GOMES, Júlio Manuel Vieira. op. cit., v. 1, p. 329.

${ }^{257}$ Meios de vigilância a distância

1 - O empregador não pode utilizar meios de vigilância a distância no local de trabalho, mediante o emprego de equipamento tecnológico, com a finalidade de controlar o desempenho profissional do trabalhador.

2 - A utilização de equipamento referido no número anterior é lícita sempre que tenha por finalidade a proteç̧ão e segurança de pessoas e bens ou quando particulares exigências inerentes à natureza da actividade o justifiquem.
} 
desempenho profissional. Apesar de a previsão legal fazer referência aos sistemas de circuito interno de televisão, a proibição não se limita aos sistemas de câmara de vídeo, mas a qualquer tipo de sistema de controle quantitativo ou descritivo das atividades realizadas, desde que a vigilância não seja realizada de modo presencial e imediatamente perceptível.

No entanto, a proibição de fiscalização na legislação portuguesa não é absoluta, na medida em que o mesmo artigo 20 do Código do Trabalho autoriza o controle a distância quando a utilização do meio de vigilância tiver como finalidade a proteção e a segurança de pessoas e bens ou quando a natureza da atividade exercida pelo empregado ou pelo empregador assim exigir; nesses casos, o empregador deve informar ao empregado sobre a existência e a finalidade dos meios de vigilância utilizados, sendo obrigatória, também, a afixação de cartazes indicativos sobre a utilização do sistema de vigilância.

A exceção do artigo 20 do Código do Trabalho português, tal como ocorre com os dispositivos legais anteriormente analisados, subordina-se ao critério de necessidade, proporcionalidade e adequação. $\mathrm{O}$ que se pretende é evitar que os sistemas de controle a distância sejam utilizados com a única e exclusiva finalidade de controle do modo de execução das tarefas por parte do empregado.

Os dados decorrentes das gravações e fiscalizações eletrônicas são considerados dados pessoais, razão pela qual o artigo 21 do Código do Trabalho de Portugal ${ }^{258}$ determina que a utilização de meios de vigilância remota no local de trabalho está condicionada à autorização da Comissão Nacional de Proteção de Dados, cujo

3 - Nos casos previstos no número anterior, o empregador deve informar o trabalhador sobre a existência e finalidade dos meios de vigilância utilizados, devendo nomeadamente afixar nos locais sujeitos os seguintes dizeres, consoante os casos: «Este local encontra-se sob vigilância de um circuito fechado de televisão» ou «Este local encontra--se sob vigilância de um circuito fechado de televisão, procedendo-se à gravação de imagem e som», seguido de símbolo identificativo.

4 - Constitui contra-ordenação muito grave a violação do disposto no n. ${ }^{\circ} 1$ e constitui contra -ordenação leve a violação do disposto no n. ${ }^{\circ} 3$.

${ }^{258}$ Utilização de meios de vigilância a distância

1 - A utilização de meios de vigilância a distância no local de trabalho está sujeita a autorização da Comissão Nacional de Protecção de Dados.

2 - A autorização só pode ser concedida se a utilização dos meios for necessária, adequada e proporcional aos objectivos a atingir.

3 - Os dados pessoais recolhidos através dos meios de vigilância a distância são conservados durante o período necessário para a prossecução das finalidades da utilização a que se destinam, devendo ser destruídos no momento da transferência do trabalhador para outro local de trabalho ou da cessação do contrato de trabalho.

4 - O pedido de autorização a que se refere o $n^{\circ} 1$ deve ser acompanhado de parecer da comissão de trabalhadores ou, não estando este disponível 10 dias após a consulta, de comprovativo do pedido de parecer.

5 - Constitui contra -ordenação grave a violação do disposto no $\mathrm{n}^{\mathrm{o}} 3$. 
requerimento de autorização deve estar acompanhado de parecer da comissão de trabalhadores. A autorização somente será concedida caso demonstrada a necessidade, adequação e proporcionalidade dos objetivos buscados com a fiscalização e manutenção dos dados. Uma vez autorizada a utilização do respectivo sistema de controle, o empregador deverá cuidar como irá tratar esses dados, na medida em que o item 3 do artigo 21 do Código do Trabalho de Portugal determina que os dados pessoais recolhidos deverão ser conservados durante o período necessário para o desenvolvimento da finalidade para a qual se destina, devendo ser destruído no momento da rescisão do contrato de trabalho ou quando da transferência do empregado para outro local de trabalho.

As soluções encontradas pela legislação estrangeira em matéria de sistema de controle presencial ou remoto nos parecem razoáveis e podem ser aplicadas no Brasil. Não há como admitir a utilização do sistema de controle presencial ostensivo e intimidador com a exclusiva finalidade de controlar a produtividade do empregado. De igual forma, o sistema de controle eletrônico a distância também não nos parece justificável em razão da simples necessidade de controle da produtividade do empregado.

O controle ostensivo intimida e o controle a distância deixa o empregado em constante alerta, pois não sabe e sequer tem condições de saber por quem, quando e como está sendo fiscalizado. Trata-se, portanto, de instrumentos de fiscalização - sendo a fiscalização um dos desdobramentos do poder diretivo - que, se não utilizados com proporcionalidade, necessidade e adequação, poderão afrontar a dignidade e a privacidade do trabalhador.

Por esse raciocínio, a utilização de sistemas de controle somente seria possível quando necessária para o estrito exercício da atividade, como o controle técnico da produção, por exemplo, e quando necessária para garantir a segurança do ambiente no qual os trabalhadores estão inseridos. O controle a distância com a simples finalidade de controle da produção não é possível, pois não é um meio necessário, adequado e proporcional para este fim.

Esta posição é confirmada por Jorge Luiz Souto Maior, que entende que no ambiente de trabalho a vigilância por sistemas de vídeo somente se justifica nos restritos limites da manutenção da segurança, sustentando que fora desse limite as câmeras servem 
somente para manter o empregado sob extremo controle, o que extrapola os limites do poder de direção do empregador, ferindo, por decorrência, a intimidade do empregado. ${ }^{259}$

Em posição contrária, Alice Monteiro de Barros entende ser possível a utilização de sistemas de vigilância por vídeo, inclusive para verificar a produtividade dos empregados, por inexistir dispositivo legal vedando tal prática na legislação brasileira. No entanto, sustenta que a utilização dos sistemas de vigilância no ambiente de trabalho não pode ser utilizada de forma indistinta, sendo vedada a fiscalização do empregado em locais privados por natureza ou que se destinam ao seu descanso, tais como banheiro ou cantina. Entende que a "vigilância eletrônica poderá ter um futuro promissor desde que utilizada de forma humana, combatendo-se os abusos na sua utilização e permitindo-se o acesso do obreiro às informações que lhe digam respeito". ${ }^{260}$

Não concordamos com essa última posição, pois o fato de inexistir legislação pátria expressa proibindo a utilização de sistemas de vigilância remota para controle da produtividade dos empregados não autoriza a afronta à privacidade e à dignidade da pessoa humana, garantidas constitucionalmente. Pela aplicação das garantias em questão, a melhor conduta a ser praticada é a já regulada pelos países europeus, ou seja, vedar a fiscalização eletrônica como mero instrumento de medição de produtividade, autorizando a sua utilização apenas para questões técnicas e de segurança, desde que a ferramenta de vigilância eletrônica seja adequada e proporcional ao fim pretendido.

\subsection{Sistemas de gravação de conversas telefônicas}

Apesar de não ser um sistema eletrônico, a discussão referente à legalidade da gravação das conversas telefônicas no ambiente de trabalho pode ser analisada sob a mesma lógica utilizada para os sistemas eletrônicos de controle a distância. Na gravação telefônica, assim como ocorre no sistema de controle eletrônico remoto, o empregado não sabe por quem, quando e como está sendo monitorado.

O Supremo Tribunal Espanhol utiliza a redação do artigo 20.3 do Estatuto de Los Trabajadores como fundamento para a gravação de conversas telefônicas do empregado, desde que observadas certas condições, de forma a restar caracterizado um consentimento

\footnotetext{
${ }^{259}$ SOUTO MAIOR, Jorge Luiz. op. cit., p. 112.

${ }^{260}$ BARROS, Alice Monteiro de. Curso de direito do trabalho, cit., p. 567-568.
} 
tácito do empregado ao tomar ciência de que suas ligações são passíveis de monitoramento. ${ }^{261}$

O artigo 20 do Código do Trabalho de Portugal refere-se à utilização de meios de vigilância a distância e o artigo 21 faz referência à confidencialidade das mensagens e de acesso à informação, sendo que Julio Manuel Vieira Gomes utiliza esses dispositivos legais para sustentar a proibição da gravação das ligações telefônicas realizadas pelo trabalhador com telefones da empresa. $\mathrm{O}$ autor refuta totalmente a conversa oculta, ou seja, aquela que o empregado não tem ciência, no entanto, entende possível a gravação de conversas com o conhecimento prévio do trabalhador e do terceiro (cliente), para proporcionar prova da transação comercial ou operação efetuada pela empresa (é o caso dos call centers). ${ }^{262}$

Julio Manuel Viera Gomes destaca que parte da doutrina italiana ${ }^{263}$ e francesa ${ }^{264}$ tem aceitado a possibilidade de controle das chamadas telefônicas realizadas, não através da averiguação do seu conteúdo (escuta), mas sim pela averiguação dos números discados e cujas ligações foram recebidas, assim como a duração e horário da chamada.

Assim como concluímos na análise dos sistemas eletrônicos de vigilância a distância, a gravação de conversas telefônicas somente se justifica quando necessária para o exercício da respectiva atividade ou para preservar a segurança das partes envolvidas na ligação. Por esse raciocínio, entende-se possível a gravação do conteúdo das ligações telefônicas quando o empregado de call center tiver acesso às informações e dados bancários do cliente. A proteção, nesse caso, é para o terceiro alheio à relação de empregado, qual seja, o cliente, que também tem o direito de ter os seus dados pessoais e financeiros tratados de forma sigilosa e com cautela. Outro exemplo seria o trabalho em mesas de operação financeira, nas quais o empregador, por trabalhar com ligações telefônicas para compra e venda de ações, também é obrigado legalmente a submeter o conteúdo de suas conversas telefônicas à gravação.

\footnotetext{
${ }^{261}$ THIBAULT ARANDA, Javier. Aula ministrada na Disciplina: Reforma Trabalhista - A Experiência Espanhola, na Pós-Graduação da Faculdade de Direito da Universidade de São Paulo, em set. 2008.

${ }^{262}$ GOMES, Júlio Manuel Vieira. op. cit., v. 1, p. 322.

${ }^{263} \mathrm{O}$ autor menciona Lucia D’Arcangelo, Uso privato del telefono, riservatezza e poteri di controllo del datore di lavoro, Rivista Giuridica del Lavoro e della Previdenza Sociale 2003, parte II, p. 72 e segs. In: GOMES, Júlio Manuel Vieira. op. cit., v. 1, p. 322.

${ }^{264} \mathrm{O}$ autor menciona François Vélot, Du badge à l'autocommuteur, les limites du controle, Semaine Sociale Lamy, 26 avril 2004, n. 1166, p. 10 e segs. e Bernard Bossu, Nouvelles Technologies et surveillance du salarié, Revue de Jurisprudence Sociale, 2001, p. 663 e segs. In: GOMES, Júlio Manuel Vieira. op. cit., v. 1, p. 268.
} 
Por outro lado, não se admite sob qualquer hipótese a gravação de conversas pessoais; tampouco é autorizada a gravação de conversas profissionais cuja atividade exercida pelo empregado ou cujas questões de segurança envolvidas não justificarem a necessidade de gravação do conteúdo da conversa. Nessa hipótese, é possível sustentar que qualquer monitoramento ou gravação telefônica extrapola o exercício do poder diretivo do empregador, ferindo a privacidade do empregado.

A possibilidade de gravação e monitoramento das conversas telefônicas é facultada, portanto, em casos muito excepcionais, até mesmo porque a discussão sobre a licitude desta prática adentra, também, no sigilo das comunicações telefônicas, garantia fundamental estabelecida no inciso XII do artigo $5^{\circ}$ da Constituição Federal e ilícito penal tipificado no parágrafo $1^{\circ}$ do artigo 151 do Código Penal, e através da legislação específica na Lei n. 9.296/96. Portanto, além da privacidade, busca-se proteger constitucionalmente a liberdade das comunicações.

\subsection{Contratação de espiões}

Temos notado certa tendência empresarial, principalmente naquelas atividades que envolvem comércio e prestação de serviços, em avaliar a qualidade do atendimento ou dos serviços oferecidos através da contratação de espiões, que atuam travestidos como clientes com o intuito de averiguar anonimamente a forma como o serviço é prestado pelo empregado.

Julio Manuel Vieira Gomes demonstra a sua preocupação com essa tendência e questiona a licitude desta prática. ${ }^{265}$

Considerando que o efeito da utilização de espiões é o mesmo da utilização de câmeras de vídeo ou escutas escondidas - visto que o empregado não tem ciência de que está sendo vigiado - entendemos que esta prática não pode ser utilizada com a finalidade específica de controlar a atividade ou a produtividade do empregado.

Fernando de Vicente Pachés segue a mesma linha e considera inadmissível a contratação formal de trabalhadores para exercer uma determinada atividade quando, na

\footnotetext{
${ }^{265}$ GOMES, Júlio Manuel Vieira. op. cit., v. 1, p. 321.
} 
realidade, a verdadeira atividade destes empregados consiste em fiscalizar e vigiar as atividades dos outros trabalhadores. ${ }^{266}$

O meio empregado para a avaliação e fiscalização do empregado não nos parece adequado, tampouco proporcional, visto que existem outros meios para o empregador averiguar a satisfação dos seus clientes com os serviços prestados por seus empregados. A utilização de espiões é, portanto, uma medida que representa um claro abuso de direito, razão pela qual deve ser rechaçada.

\subsection{Monitoramento do correio eletrônico (e-mail) e acesso à rede mundial de computadores (internet)}

A discussão relativa ao monitoramento do $e$-mail e internet no ambiente de trabalho é complexa e, no que concerne ao monitoramento da correspondência eletrônica, envolve, além da discussão sobre a privacidade em si, a análise do sigilo da correspondência e o limite do empregador ao dispor aos seus empregados instrumentos de trabalho, no caso específico, o computador, o provedor de internet e a conta eletrônica de e-mail.

No âmbito europeu, a discussão encontra-se mais avançada que no Brasil, conforme veremos a seguir.

O artigo 20.3 do Estatuto dos Trabalhadores da Espanha é utilizado como fundamento para monitoramento do empregado enquanto usuário do computador da empresa (e-mail e internet). Atualmente, entende-se que o monitoramento do computador não deve ser analisado sob a perspectiva do artigo 18 do Estatuto dos Trabalhadores, pois apesar de este equipamento eletrônico possuir no seu interior arquivos e dados pessoais do empregado, não é considerado como um elemento pessoal. Assim, no que se refere ao computador, deve ser aplicado, no estudo do caso concreto, a previsão do art. 20.3 do Estatuto dos Trabalhadores, que autoriza o monitoramento como exercício do poder de controle do empregador, desde que respeitada a dignidade do empregado. ${ }^{267}$

Javier Thibault Aranda sustenta que, para ser válido o monitoramento das atividades do empregado frente ao computador, alguns procedimentos devem ser

\footnotetext{
${ }^{266}$ PACHÉS, Fernando de Vicente. El Derecho Del Trabajador al Respeto de su Intimidad. Madrid: CES (Consejo Económico Y Social), 1998, p. 307, apud GOMES, Júlio Manuel Vieira. op. cit., v. 1, p. 322.

${ }^{267}$ THIBAULT ARANDA, Javier. Aula ministrada na Disciplina: Reforma Trabalhista - A Experiência Espanhola, na Pós-Graduação da Faculdade de Direito da Universidade de São Paulo, em set. 2008.
} 
observados pelo empregador, tais como informar o empregado por escrito sobre as condições de uso do computador (fins profissionais) e das eventuais situações de monitoramento, visando elidir a expectativa de privacidade. ${ }^{268}$

$\mathrm{Na}$ Espanha o tratamento do monitoramento das páginas da web (internet) visitadas pelo empregado é diverso do monitoramento da correspondência eletrônica (e-mail), pois enquanto o primeiro é tratado sob a perspectiva do artigo 20.3 do Estatuto dos Trabalhadores, o segundo é tratado como sigilo das comunicações. Assim, a violação do correio eletrônico, mais que afrontar a intimidade do empregado, afronta o sigilo das comunicações. Com base nesse entendimento, a jurisprudência da Espanha, segundo Javier Thibault Aranda, tem entendido ser necessária a concessão de duas contas de correio eletrônico: uma onde o empregado possui total liberdade e outra onde ele pode ser monitorado. $^{269}$

A confidencialidade de mensagens e de acesso à informação é tratada no artigo 22 do Código do Trabalho de Portugal $^{270}$, que resguarda o direito de reserva e confidencialidade sobre mensagens pessoais e de informações de natureza não profissional consultadas pelo empregado no tempo e no local de trabalho, através da utilização dos instrumentos colocados à disposição pelo empregador. A segunda parte do artigo 22 do Código do Trabalho apresenta exceção à regra e faculta ao empregador o estabelecimento de regras para a utilização do correio eletrônico no ambiente de trabalho.

A previsão legal portuguesa, nesse aspecto, ao possibilitar somente a adoção de práticas patronais para disciplinar o uso dos meios de comunicação da empresa, deixa a desejar, pois não enfrenta de forma clara a existência de autorização ou não para a verificação do conteúdo das mensagens profissionais recebidas pelo trabalhador no computador da empresa.

A legislação trabalhista nacional, como ocorre com a grande maioria das questões relativas à privacidade, não disciplina sobre matéria, sendo que, atualmente, não existe na doutrina uma posição unânime sobre a legalidade da prática patronal de acessar o conteúdo

\footnotetext{
${ }^{268}$ THIBAULT ARANDA, Javier. Control multimedia de la actividade laboral. Valencia: Tirant le Blanch: 2006. p. 91.

${ }^{269}$ Id. Aula ministrada na Disciplina: Reforma Trabalhista - A Experiência Espanhola, cit.

${ }^{270}$ Confidencialidade de mensagens e de acesso a informação.

1 - O trabalhador goza do direito de reserva e confidencialidade relativamente ao conteúdo das mensagens de natureza pessoal e acesso a informação de carácter não profissional que envie, receba ou consulte, nomeadamente através do correio electrónico.

2 - O disposto no número anterior não prejudica o poder de o empregador estabelecer regras de utilização dos meios de comunicação na empresa, nomeadamente do correio electrónico.
} 
das mensagens eletrônicas enviadas e páginas da web visitadas pelos empregados. A discussão da doutrina encontra-se dividida, de forma geral, em duas correntes: i) aqueles que argumentam não ser possível a violação da intimidade e da privacidade do empregado, entendendo ser ilegal o monitoramento de e-mail e internet no ambiente de trabalho; e ii) aqueles que utilizam o exercício do poder diretivo e o direito de propriedade da empresa sobre os instrumentos de trabalho para legitimar o monitoramento cibernético no ambiente de trabalho.

O primeiro grupo defende a garantia da privacidade e da intimidade do empregado no ambiente de trabalho, não admitindo qualquer intromissão na vida privada do trabalhador, por sustentar que o poder de direção não poderá se sobrepor à preservação dos direitos da personalidade do empregado, que são indisponíveis e irrenunciáveis. Ainda, existem os que justificam a vedação do monitoramento da correspondência eletrônica na proteção do sigilo de correspondência, equiparando o meio eletrônico ao de papel. ${ }^{271}$

Apesar de concordarmos com a posição da primeira corrente no sentido de defender a necessidade de preservação da reserva da vida privada do empregado, entendemos que o correio eletrônico deve ser concebido como uma comunicação de dados e não como correspondência.

Em razão dessa posição, não concordamos com a corrente que justifica a impossibilidade do monitoramento de e-mail na disposição constitucional que protege o sigilo das correspondências. Entendemos não ser possível equiparar o correio tradicional ao correio eletrônico, por possuírem características distintas: enquanto a correspondência tradicional é fechada e somente pode ser encaminhada para um destinatário (ainda que se encaminhe uma mesma carta para várias pessoas, não haverá simultaneidade no recebimento da correspondência, pois o documento terá que ser transmitido de uma pessoa para a outra), a correspondência eletrônica é aberta, podendo ser enviada de forma ágil para um infinito número de destinatários. Entendemos, portanto, que em razão das características do correio eletrônico não é possível aplicar a este meio de comunicação a proteção conferida às correspondências tradicionais.

\footnotetext{
${ }^{271} \mathrm{Na}$ primeira corrente destacamos Alice Monteiro de Barros (Proteção à intimidade do empregado, cit., p. 33), Tulio Lima Vianna (VIANNA, Túlio Lima. Violação à privacidade: quero monitorar os e-mails dos ministros do TST! Conjur. Disponível em: <http://www.conjur.estadao.com.br>. Acesso em: 21 maio 2005); e Eduardo Milleó Baracat (BACARAT, Eduardo Milléo. A boa-fé no direito individual do trabalho. São Paulo: LTr, 2002. p. 245).
} 
Os argumentos que utilizamos para defender a impossibilidade de violação do conteúdo das mensagens enviadas e recebidas nos computadores consistem na aplicação da cláusula de tutela geral da privacidade do trabalhador.

Para o segundo grupo, a inserção do trabalhador no ambiente de trabalho patronal, o estado de subordinação a que o empregado se coloca na relação de emprego e o exercício do poder diretivo patronal, assim como o direito de propriedade do empregador autorizam a fiscalização do conteúdo das mensagens eletrônicas enviadas e páginas acessadas na internet pelo trabalhador. Para essa corrente doutrinária, o poder de fiscalização do empregador confere a este a prerrogativa de verificar as atividades desenvolvidas pelo empregado no horário de trabalho, limitando ou, até mesmo, se sobrepondo ao resguardo da privacidade do obreiro. A mesma corrente sustenta que a empresa, por ser proprietária dos computadores, do programa de software, do provedor e da linha telefônica, tem o direito de dispor dos referidos bens para o desenvolvimento da sua atividade, podendo limitar e monitorar o uso dos meios de produção. ${ }^{272}$

Ousamos também em discordar do segundo grupo de doutrinadores em razão de sustentarmos que o direito de propriedade patronal, por si só, não tem o condão de afastar a garantia à privacidade do empregado e, tampouco, que o exercício do poder diretivo não autoriza o empregador a violar direitos personalíssimos do trabalhador ${ }^{273}$.

Sustentamos ser possível estabelecer uma terceira via de entendimento quanto à matéria, para defender a impossibilidade de acesso total ao conteúdo das mensagens eletrônicas (pessoais ou profissionais) enviadas pelos empregados no ambiente de trabalho, mas, ao mesmo tempo, aceitar a possibilidade de imposição de algumas limitações ao trabalhador na utilização do computador, do correio eletrônico e dos provedores de internet colocados à sua disposição pelo empregador.

Defendemos, como regra geral, portanto, a proibição de qualquer atitude patronal que tenha como finalidade simplesmente acessar o conteúdo das mensagens enviadas ou destinadas ao trabalhador.

\footnotetext{
${ }^{272} \mathrm{Na}$ segunda corrente podemos incluir Estevão Mallet, para quem o poder de direção é o principal limitador da privacidade do empregado. Para o doutrinador, não havendo proibição expressa na legislação trabalhista para a fiscalização por meio eletrônico - diversamente do que ocorre em outros países - deve-se considerar lícita a prática (MALLET, Estêvão. op. cit., p. 15). Sérgio Pinto Martins também fundamenta a legalidade do monitoramento de e-mail no exercício do poder diretivo do empregador (MARTINS, Sérgio Pinto. op. cit., p. 225).

${ }^{273}$ Nesse sentido, nos reportamos ao capítulo 3 do presente trabalho.
} 
Como exceção a essa regra, entendemos que o empregador estará autorizado a limitar a utilização do correio eletrônico e o acesso à internet no ambiente de trabalho não em razão do exercício do seu poder diretivo ou de propriedade, mas sim por obrigação legal. Nossos argumentos estão fundamentados na responsabilidade que é atribuída ao empregador por atos praticados por seus prepostos ou empregados no exercício da atividade laboral, em razão da redação do artigo 932, inciso III do Código Civil. A responsabilidade determinada por esse dispositivo legal é objetiva e decorre de vários fatores, dentre eles, a culpa in vigilando, que decorre da falha patronal no ato de fiscalizar os seus empregados de forma a evitar a prática de atos ilícitos. Utilizando a lógica do inciso III do artigo 932 do Código Civil, se ao empregador é atribuída a responsabilidade pelos atos praticados por seus empregados durante a jornada de trabalho, por consequência a ele é também imposto o dever de fiscalizar a atuação de seus subordinados, a fim de evitar a prática de atos que causem prejuízos a terceiros a que possa ser responsabilizado.

Melhor explicando, é possível sustentar a limitação da privacidade do empregado na utilização de e-mail e internet no ambiente de trabalho sob o fundamento da preservação de um bem e interesse maior, qual seja, a segurança de terceiros, já que é sabido que a má utilização do correio eletrônico pode dar ensejo à prática de crimes e prejuízos contra terceiros. ${ }^{274}$ Cabe ao empregador, como responsável pelos atos de seus subordinados no ambiente de trabalho, coibir tal prática enquanto estes estiverem sob suas ordens, de forma a garantir que os instrumentos de trabalho colocados à disposição de seus empregados não sejam utilizados para a prática de atos ilícitos para lesar interesses e bens de terceiros alheios à relação de emprego.

Assim, diante da responsabilidade do empregador perante terceiros, que impõe ao primeiro a obrigação de zelar para impedir a utilização indevida dos instrumentos de trabalho colocados à disposição do trabalhador, de forma a causar prejuízos a terceiros, o empregador está autorizado a estabelecer critérios objetivos para a verificação da atuação do empregado frente à internet e ao correio eletrônico. Ou seja, a intimidade do empregado não é limitada em decorrência do direito de propriedade do empregador sobre o computador ou do exercício do seu poder diretivo, mas sim em razão do interesse público

\footnotetext{
${ }^{274}$ Apenas para citar alguns exemplos, os equipamentos eletrônicos colocados à disposição pela empresa poderão ser utilizados indevidamente para o envio de mensagens com pedofilia, vírus, pornografia; prática de transações ilícitas pela internet; acesso a contas bancárias de forma ilegal; prática de jogos de azar; invasão de banco de dados, informações bancárias e fiscais, etc.
} 
envolvido, para que o uso ilícito da internet e do correio eletrônico não vise à prática de atividades ilícitas ou para causar prejuízos a terceiros alheios à relação de emprego.

Nesse ponto, cumpre esclarecer que o poder/dever conferido ao empregador como reflexo da sua responsabilidade objetiva pelos atos praticados por seus empregados e prepostos não pode ser confundido com poder de polícia, cuja atribução é do Estado e visa estabelecer, em benefício da ordem social e jurídica, medidas necessárias para a manutenção da ordem, da moralidade, da saúde pública ou a garantia de direitos fundamentais dos particulares e o bem-estar coletivo. Trata-se, na realidade, do exercício do poder de fiscalização patronal, que decorre do poder de direção e da responsabilidade objetiva prevista no inciso III do artigo 932 do Código Civil.

Para que a limitação ora sustentada seja considerada legítima e resulte no menor prejuízo ao direito personalíssimo do empregado, defendemos que o monitoramento deverá ser realizado de forma criteriosa, como meio de garantir o máximo da preservação da privacidade do trabalhador, aplicando-se a premissa de limitação mínima visando a máxima garantia do direito. Por este raciocínio, entendemos que o empregador está autorizado a acessar o conteúdo das mensagens ou páginas visitadas pelo empregado somente nas hipóteses em que houver a concreta suspeita de que o computador, o software, o provedor, ou outros instrumentos eletrônicos fornecidos pela empresa, estão sendo utilizados indevidamente de forma a causar danos ou prejuízos a terceiros.

Os indícios que levarão o empregador a suspeitar do empregado de forma a autorizar a verificação das mensagens e páginas da web visitadas serão constatados através da forma como o empregado se comporta frente ao computador. Se o empregado envia uma única mensagem a um número excessivo de destinatários; se abre páginas ou envia mensagens que contenham palavras relacionadas a sexo, pedofilia e correlatas; se envia ou recebe mensagens contendo arquivos com imagens com tamanho acima do normal, existem indícios razoáveis de que o computador da empresa está sendo utilizado de forma ilícita.

Nestas hipóteses - que serão constatadas através do estabelecimento de critérios objetivos, como tamanho da mensagem, número de destinatários, tipos de páginas da internet - sustentamos ser possível monitorar as mensagens enviadas e páginas visitadas pelos seus empregados durante a jornada de trabalho. 


\subsection{Revista íntima e revista pessoal}

No âmbito da concretização da proteção da esfera privada do trabalhador, no Brasil, a proibição da revista íntima é única previsão expressa que existe na legislação ordinária no âmbito do direito do trabalho, mais precisamente no artigo 373-A da Consolidação das Leis do Trabalho. ${ }^{275}$ Tal dispositivo legal, em razão do princípio da igualdade, previsto no $\operatorname{artigo~} 5^{\circ}$, inciso I da Constituição Federal ${ }^{276}$ não está limitado às mulheres, sendo também aplicável aos empregados de sexo masculino.

A revista íntima, por expressa vedação legal, é proibida, portanto. Não há como abrir qualquer exceção a esta regra diante da proibição legal, sendo que qualquer prática adotada pelo empregador neste sentido será considerada ilegal.

Em razão de o artigo 373-A da Consolidação das Leis do Trabalho somente vedar a revista íntima, nada dispondo sobre a revista pessoal, discute-se na doutrina e na jurisprudência se este segundo tipo de revista está autorizado, indiretamente, pela legislação.

Antes de analisarmos a licitude ou não da revista pessoal, faz-se necessário estabelecer a diferenciação entre este tipo de revista e a íntima. A expressão "íntima" remete à ideia de intimidade, podendo ser relacionada à revista realizada em partes íntimas, estando, portanto, ligada às partes íntimas do corpo. Já a revista pessoal, é realizada sobre a pessoa do indivíduo sem adentrar na sua intimidade. A bolsa ou sacola do empregado, bem como os armários onde o trabalhador guarda os seus pertences pessoais, por não estarem relacionados a partes íntimas do corpo, devem ser concebidos como bens pessoais, razão pela qual deverão ser analisados sob a perspectiva da revista pessoal e não íntima.

Há uma parte da doutrina ${ }^{277}$ que entende não ser possível a revista pessoal, por adentrar na esfera de resguardo do empregado sob pretexto meramente patrimonial.

Entretanto, outra parte da doutrina entende ser possível a revista pessoal, por decorrer do exercício do poder de direção e controle do empregador, com o objetivo de

\footnotetext{
${ }^{275}$ Art. 373-A. Ressalvadas as disposições legais destinadas a corrigir as distorções que afetam o acesso da mulher ao mercado de trabalho e certas especificidades estabelecidas nos acordos trabalhistas, é vedado: (...) VI - proceder o empregador ou preposto a revistas íntimas nas empregadas ou funcionárias (...)

${ }^{276}$ Art. $5^{\circ}$ Todos são iguais perante a lei, sem distinção de qualquer natureza, garantindo-se aos brasileiros e aos estrangeiros residentes no País a inviolabilidade do direito à vida, à liberdade, à igualdade, à segurança e à propriedade, nos termos seguintes: I - homens e mulheres são iguais em direitos e obrigações, nos termos desta Constituição

${ }^{277}$ Dentre outros, citamos SIMÓN, Sandra Lia. op. cit.
} 
evitar prejuízos ao patrimônio do empregador, desde que realizada sem caráter discriminatório e sem afrontar a intimidade e a privacidade do empregado. Uma terceira vertente da doutrina entende ser possível a revista pessoal somente nas hipóteses de segurança das próprias pessoas que circulam no ambiente de trabalho.

Alice Monteiro de Barros entende que a revista se justifica apenas quando constituir o último meio a ser utilizado pelo empregador para garantir a segurança de seu patrimônio e a salvaguarda da segurança das pessoas que circulam no ambiente de trabalho. Sustenta que a genérica alegação de propriedade não justifica a revista, sendo que devem existir na empresa bens suscetíveis de subtração e ocultação, com valor material ou relevância para o funcionamento empresarial. Argumenta, também, que se existirem outros meios de garantir a segurança no ambiente de trabalho, estes sempre deverão ser utilizados em detrimento da revista. De qualquer sorte, quando a revista for inevitável, Alice Monteiro de Barros defende que esta deve ser feita em caráter geral, impessoal, por meio de critério objetivo, mediante ajuste prévio com a entidade sindical ou com o próprio empregado; na falta daquela, respeitando-se, ao máximo, a honra, a intimidade e os demais direitos da personalidade do empregado. $^{278}$

$\mathrm{O}$ artigo $6^{\circ}$ do Statuto dei Lavoratori da Itália proíbe as revistas pessoais, salvo nos autos em que são indispensáveis para a proteção dos ativos da empresa em relação à qualidade das ferramentas de trabalho, às matérias-primas ou aos produtos. Nesses casos, o artigo disciplina que as revistas devem ser realizadas na saída do trabalho, com a aplicação de sistemas de seleção automática à coletividade ou a grupos de empregados e respeitando a dignidade e a privacidade dos empregados. As hipóteses e condições nas quais será permitida a revista pessoal, como também as correspondentes modalidades deverão ser acordadas entre o empregador e o representante sindical ou, na falta deste, a comissão interna.

O artigo 18 do Estatuto de Los Trabajadores da Espanha trata da revista da pessoa do trabalhador, do armário e de seus pertences pessoais. O dispositivo legal prevê que a revista somente se justifica quando visa resguardar o patrimônio da empresa ou de seus trabalhadores, sendo que, para tanto, deve ser realizada no horário de trabalho, respeitando ao máximo a dignidade e a privacidade do empregado, além de realizar-se na presença de um representante legal dos trabalhadores ou se este não estiver presente, na presença de outro trabalhador.

\footnotetext{
${ }^{278}$ BARROS, Alice Monteiro de. Curso de direito do trabalho, cit., p. 558.
} 
Segundo Javier Thibault Aranda, o Supremo Tribunal da Espanha entende que a gaveta do local de trabalho, apesar de conter pertences pessoais do empregado, não é considerada como "pessoal”, pois é um instrumento da empresa. ${ }^{279}$

Para Alice Monteiro de Barros, o artigo 18 do Estatuto de Los Trabajadores tem sido objeto de várias críticas pela doutrina, sob o argumento de que o empregado poderá resistir a essa ordem, por ser ilegítima, eis que o preceito vulnera o direito à privacidade do empregado e a presunção de inocência consagrada no artigo 24.4 da Constituição espanhola. $^{280}$

Apesar da omissão do Código do Trabalho de Portugal sobre a matéria, Julio Manuel Vieira Gomes entende ser possível a revista pessoal quando esta for o único meio apto para a proteção dos trabalhadores ou do patrimônio da empresa. No entanto, defende que as revistas deverão ser realizadas com o máximo de respeito à dignidade do trabalhador, devendo ser feitas com a maior discrição e menor publicidade, contando sempre com a presença de um representante dos trabalhadores ou, pelo menos, de outro trabalhador escolhido pelo revistado. ${ }^{281}$

Em razão das premissas estabelecidas no capítulo 3, não aceitamos a hipótese de revistas pessoais com o exclusivo intuito de proteção patrimonial do empregador. Conforme já sustentado, o direito fundamental à propriedade privada - de cunho nitidamente patrimonial - não é suficiente para anular ou até mesmo limitar a privacidade do trabalhador, já que este direito fundamental está intimamente ligado à dignidade da pessoa humana. O empregador pode dispor de outros meios de controle e segurança do seu patrimônio, sendo que a revista pessoal não se mostra o meio necessário e imprescindível para a proteção patrimonial patronal.

No entanto, existem situações em que a revista pessoal do trabalhador é requisito para a execução do próprio contrato de trabalho ou, ainda, deve ser aplicada para resguardar a segurança ou a saúde da coletividade, envolvendo bens maiores e que, portanto, devem ser devidamente ponderados com a privacidade do trabalhador. É o caso, por exemplo, dos trabalhadores em indústrias farmacêuticas que produzem remédios de uso controlado ou que fabricam ou manipulam matéria-prima, insumo ou produto químico destinado à preparação de drogas.

\footnotetext{
${ }^{279}$ THIBAULT ARANDA, Javier. Aula ministrada na Disciplina: Reforma Trabalhista - A Experiência Espanhola, cit.

${ }^{280}$ BARROS, Alice Monteiro de. Curso de direito do trabalho, cit., p. 564.

${ }^{281}$ GOMES, Júlio Manuel Vieira. op. cit., v. 1, p. 335.
} 
A Portaria n. ${ }^{\circ}$ 344, de 12 de maio de 1998, da Agência Nacional de Vigilância Sanitária (que aprova o Regulamento Técnico sobre substâncias e medicamentos sujeitos a controle especial) apresenta um rol das substâncias que deverão ter a sua produção e transporte controlados, obrigando a fabricante destes produtos a adotar todas as medidas de segurança e fiscalização necessárias para evitar que saiam do âmbito da fábrica sem autorização ou controle.

Por sua vez, o parágrafo $1^{\circ}$ do artigo 33 da Lei $n^{\circ} 11.343$, de 23.08.2006 que, entre outras providências, estabelece normas para repressão à produção não autorizada e ao tráfico ilícito de drogas, tipifica como crime a produção de matéria-prima, insumo ou produto químico destinado à preparação de drogas ou de plantas que constituam matéria prima para a preparação de drogas. ${ }^{282}$

À luz dos dispositivos legais ora invocados, temos que o empregador possui a obrigação de controlar o armazenamento e circulação destas substâncias e medicamentos controlados, sob pena de os seus administradores, na omissão, praticarem crime tipificado no parágrafo $1^{\circ}$ do artigo 33 da Lei 11.343/06. Mais do que um poder fiscalizatório, há, neste caso, dever de fiscalização. A verificação pessoal do empregado que mantém contato direto ou manipula substâncias arroladas pela Portaria n. ${ }^{\circ}$ 344/98 da ANVISA é condição necessária para a própria execução do contrato, como uma forma de garantir a segurança e a saúde da população em geral.

Mesmo nas hipóteses em que sustentamos ser possível a revista pessoal, entendemos que a verificação da bolsa, armários ou pertences pessoais do empregado deve ser realizada somente com a autorização e a presença do trabalhador, como instrumento necessário para garantir a manutenção da dignidade do empregado.

\footnotetext{
${ }^{282}$ Art. 33. Importar, exportar, remeter, preparar, produzir, fabricar, adquirir, vender, expor à venda, oferecer, ter em depósito, transportar, trazer consigo, guardar, prescrever, ministrar, entregar a consumo ou fornecer drogas, ainda que gratuitamente, sem autorização ou em desacordo com determinação legal ou regulamentar.

Pena - reclusão de 5 (cinco) a 15 (quinze) anos e pagamento de 500 (quinhentos) a 1.500 (mil e quinhentos) dias-multa.

$\S 1^{\circ}$ Nas mesmas penas incorre quem:

I - importa, exporta, remete, produz, fabrica, adquire, vende, expõe à venda, oferece, fornece, tem em depósito, transporta, traz consigo ou guarda, ainda que gratuitamente, sem autorização ou em desacordo com determinação legal ou regulamentar, matéria-prima, insumo ou produto químico destinado à preparação de drogas;

II - semeia, cultiva ou faz a colheita, sem autorização ou em desacordo com determinação legal ou regulamentar, de plantas que se constituam em matéria-prima para a preparação de drogas;

III - utiliza local ou bem de qualquer natureza de que tem a propriedade, posse, administração, guarda ou vigilância, ou consente que outrem dele se utilize, ainda que gratuitamente, sem autorização ou em desacordo com determinação legal ou regulamentar, para o tráfico ilícito de drogas
} 
Concluímos, portanto, que a revista íntima, por expressa vedação legal, é proibida, sendo que a revista pessoal somente será autorizada quando constituir requisito essencial para a execução do próprio contrato de trabalho ou quando for necessária para garantir a preservação da segurança ou da saúde da coletividade. Nas hipóteses em que a revista pessoal for admitida, o empregador deverá adotar todas as precauções necessárias no sentido de garantir ao máximo o respeito à privacidade do trabalhador, conforme recomendações indicadas na parte final do capítulo 3 do presente trabalho.

\subsection{Controle por meio de polígrafo - detector de mentiras}

Apesar de o polígrafo - também conhecido como "detector de mentiras" - ter caído em desuso nos Estados Unidos após a edição da Public Law 100-347, de 27 de junho de 1988, também conhecida como Employee Polygraph Protection Act of 1988 (EPPA) ${ }^{283}$, que proíbe a utilização de detector de mentiras para a contratação e durante a execução do contrato de trabalho, a análise da jurisprudência brasileira revela que essa prática ainda continua ocorrendo no Brasil. ${ }^{284}$

Sob qualquer ângulo que se analise, não há qualquer argumento plausível capaz de justificar a aplicação do polígrafo no ambiente de trabalho.

Em primeiro lugar, não há qualquer prova de que o polígrafo possa efetivamente medir se o indivíduo está mentindo ou se é desonesto; assim, a validade das informações fornecidas por este instrumento, por si só, já é questionável.

Em segundo lugar, conforme já sustentado, o empregado não tem obrigação de responder perguntas que não estão estritamente relacionadas com a execução do contrato de trabalho, sendo-lhe facultado omitir ou, até mesmo, mentir sobre dados pessoais cuja obrigatoriedade de prestar informação não possui.

Em terceiro lugar, conforme também já sustentado, o contrato de trabalho deve ser executado de boa-fé, sendo que os atos das partes sempre devem estar pautados pela

\footnotetext{
${ }^{283}$ UNITED STATES DEPARTAMENT OF LABOUR. Employee Polygrafh Protection Act of 1988. Disponível em: <http://www.dol.gov/esa/whd/regs/statutes/poly01.pdf>. Acesso em: 28 jun. 2009.

${ }^{284}$ Como exemplo, citamos os julgamentos (TRT $2^{\mathrm{a}} \mathrm{R}$. - RO 01262-2002-316-02-00 - (20050873860) - 6 $6^{\mathrm{a}} \mathrm{T}$. - Rel. p/o Ac. Juiz Rafael E. Pugliese Ribeiro - DOESP 13.01.2006); (TRT 2 ${ }^{\mathrm{a}}$ R. - RO 01275-2003-31102-00 - (20050694051) - 6 $6^{\mathrm{a}}$ T. - Rel. p/o Ac. Juiz Valdir Florindo - DOESP 14.10.2005); e (TRT $3^{\mathrm{a}}$ R. RO 00298-2003-092-03-00-0 - 1 a T. - Rel. Juiz Manuel Cândido Rodrigues - DJMG 30.04.2004 - p. 05), todos obtidos através do acesso ao JÚRIS Sintese IOB, mar./abr. 2009. CD-ROM.
} 
confiança, o que, evidentemente, não abre qualquer espaço para a utilização de qualquer instrumento que coloque em xeque a idoneidade ou o caráter do trabalhador.

Em quarto lugar, é evidente que a utilização de equipamento técnico questionável, para fins de avaliação da idoneidade do trabalhador, como instrumento inadequado e evidentemente falho, só por si, acaba por representar um ato de constrangimento ao empregado.

Em quinto lugar, mesmo que fosse possível admitir eficiência do resultado obtido através do detector de mentiras, não há dúvidas de que a investigação sobre estado íntimo e não manifestamente expresso - do empregado configura total violação da pessoa e da dignidade do trabalhador.

Não se admite, portanto, qualquer justificativa ou interesse maior capaz de autorizar a aplicação do detector de mentira, sendo que a utilização deste método representa um atentado à privacidade e à dignidade do empregado. 


\section{INSTRUMENTOS PARA A CONCRETIZAÇÃO DA PRIVACIDADE}

Estabelecidas as premissas necessárias para a concretização da privacidade no ambiente de trabalho e, após a aplicação destas aos diversos casos concretos onde este direito fundamental é suscetível de ofensa, não poderíamos deixar de analisar, sem a pretensão de aprofundar e esgotar o tema ${ }^{285}$, os instrumentos colocados à disposição no âmbito da relação de emprego para fazer valer o direito à privacidade do trabalhador.

De nada adiantaria a extração de conceitos na Constituição Federal e na legislação ordinária para concretizar a privacidade do trabalhador se não existissem instrumentos capazes de garantir a sua efetividade. Isso porque, conforme destaca Raimundo Simão de Melo, a garantia da proteção efetiva dos direitos fundamentais se dá através da utilização dos instrumentos eficazes pelos legitimados. ${ }^{286}$

Essas medidas visam evitar a afronta à privacidade do empregado, estabelecendo vedações ao empregador no exercício do seu poder diretivo. Nesse sentido, o papel do empregado, dos sindicatos, dos Auditores Fiscais do Trabalho e do Ministério Público do Trabalho é muito importante, pois a estes cumpre zelar por um ambiente de trabalho sadio, que também compreende o respeito aos direitos da personalidade do trabalhador.

\subsection{Ações preventivas}

O artigo 21 do Código Civil possibilita ao interessado a adoção das providências necessárias para impedir ou fazer cessar atos que ocasionem violação aos direitos da personalidade.

Por representar um direito individual de primeira geração, que atinge o indivíduo de forma direta, por regra geral, a tutela da privacidade é realizada individualmente. No entanto, no âmbito da relação de emprego a tutela individual preventiva da privacidade não

\footnotetext{
${ }^{285}$ Por não ser o objeto principal do trabalho e em razão da complexidade das discussões que a matéria envolve.

${ }^{286}$ MELO, Raimundo Simão de. op. cit., p. 83.
} 
se apresenta efetiva, pois ao exercê-la o empregado ou candidato à vaga de emprego se expõe, colocando em risco o seu próprio emprego ou a sua contratação.

O trabalhador, em razão da sua posição de hipossuficiência na relação de emprego, normalmente terá maiores dificuldades para fazer valer os seus direitos na resistência aos avanços do empregador contra a sua esfera privada. Isso porque a legislação brasileira não prevê qualquer garantia contra a dispensa arbitrária ou sem justa causa, bem como a jurisprudência dos tribunais trabalhistas tem sido pouco receptiva quanto à aplicação da teoria do abuso de direito a este tipo de dispensa, o que, de fato, dificulta o exercício individual de ação. Além disso, a instabilidade econômica mundial, refletida de modo especialmente forte no mercado de trabalho, tem sido outro fator a impedir ações da autoproteção eficazes por parte dos trabalhadores. ${ }^{287}$

Desta forma, embora o direito de ação seja garantido constitucionalmente a todos os cidadãos, o exercício deste direito por parte do empregado de forma preventiva, ou seja, durante a execução do contrato de trabalho, não é efetivo, em razão da posição de hipossuficiência do trabalhador. ${ }^{288}$

Diante desta dificuldade, os órgãos de representação dos trabalhadores dentro da empresa (comissão de fábrica, CIPA), os sindicatos, a fiscalização do trabalho e o Ministério Público do Trabalho exercem papel importante para assegurar a concretização da privacidade do empregado, pois o trabalhador, individualmente, pouco ou nada poderá fazer frente ao exercício abusivo do poder diretivo do empregador. Além da dificuldade para o exercício do direito de ação antes e durante a execução do contrato, o próprio jus resistentiae do empregado frente a uma ordem patronal ofensiva à privacidade é prejudicado, visto a sua posição de hipossuficiência e dependência econômica ao emprego.

Assim, no âmbito da relação de emprego, os órgãos de representação dos trabalhadores, os sindicatos, auditores fiscais e membros do Ministério Público do Trabalho devem agir de forma a prevenir a adoção de práticas por parte do empregador que representem o afastamento ou uma limitação ilegítima da privacidade do empregado. De igual forma, nas oportunidades em que esta limitação for possível, de acordo com as exceções verificadas no capítulo 3 do presente trabalho, os órgãos internos de representação dos trabalhadores, os sindicatos representantes das respectivas categorias e, na falta destes, o Ministério Público do Trabalho devem estar presentes no processo de

\footnotetext{
${ }^{287}$ REZENDE, Roberto Vieira de Almeida. op. cit., p. 196.

${ }^{288}$ SIMÓN, Sandra Lia. op. cit., p. 187.
} 
regulamentação da prática limitadora a ser implementada pelo empregador, visando garantir maior efetividade ao direito da privacidade dos trabalhadores afetados.

Os órgãos internos de representação dos empregados, por estarem inseridos na rotina da empresa, em razão do contato direto com os trabalhadores envolvidos e por estarem amparados pela garantia de emprego conferida por lei, podem ser considerados como os sujeitos mais aptos a adotar práticas preventivas para garantir a concretização da privacidade no ambiente de trabalho.

O sindicato, como associação profissional, cuja atribuição é a defesa dos interesses coletivos ou individuais da categoria profissional que representa, inclusive em questões judiciais e administrativas, também desempenha papel importante na salvaguarda da privacidade do trabalhador. Os sindicatos devem atuar como garantidores e fiscalizadores da idoneidade dos métodos utilizados pelo empregado para limitar a privacidade dos trabalhadores. Conforme destacado no capítulo 3, o papel do sindicato é importantíssimo, pois além de democratizar o ambiente de trabalho, possibilitando uma maior participação dos trabalhadores através da negociação coletiva, garantirá a transparência e a adequação das práticas adotadas pelo empregador.

Raimundo Simão de Melo, ao discorrer sobre o papel dos sindicatos na defesa do meio ambiente do trabalho, sustenta que, atualmente, cabe cada vez mais às entidades sindicais a defesa da saúde dos trabalhadores, principalmente por intermédio da negociação coletiva, apoiada pelo direito de greve. ${ }^{289}$

No que diz respeito ao movimento paredista, Raimundo Simão de Melo apresenta a possibilidade de deflagração de greve ambiental como um instrumento constitucional de autodefesa a fim de garantir a salubridade do meio ambiente de trabalho e a preservação da segurança, da saúde e da integridade física e psíquica dos trabalhadores. ${ }^{290}$

Sobre a atuação do Ministério Público na salvaguarda da privacidade dos trabalhadores na relação de emprego, Sandra Lia Simón aponta as seguintes prerrogativas do Parquet:

(i) na fase de contratação, fiscalizar todo o processo de seleção, atentando para eventuais requisitos que importem discriminação, bem como para os métodos que tenham por objetivo 'desvendar' aspectos íntimos ou privados da personalidade do trabalhador; (ii) sobre a exigência de exames médicos de quaisquer espécies, verificar aqueles que são

\footnotetext{
${ }^{289}$ MELO, Raimundo Simão de. op. cit., p. 84.

${ }^{290}$ Id. Ibid., p. 107.
} 
realizados, se são feitos com a concordância dos trabalhadores e se estes são devidamente cientificados do resultado dos mesmos; (iii) sobre as revistas, checar se há justificativa para a realização delas, bem como se os métodos utilizados não atentam contra a intimidade e a vida privada dos trabalhadores; (iv) sobre a instalação de equipamentos audiovisuais, verificar se o objetivo para a referida instalação (segurança ou fiscalização do serviço) está sendo observado e se os trabalhadores foram cientificados dela; (v) sobre a utilização de computador, checar se as fiscalizações às quais procede o empregador encontram-se nos limites do seu poder de direção; (vi) sobre os dados pessoais dos trabalhadores, analisar o motivo do seu armazenamento e sua utilização, bem como viabilizar o acesso dos trabalhadores a esses dados; (vii) sobre a liberdade de pensamento do trabalhador, fiscalizar procedimento empresariais que atentem contra esse direito; (viii) sobre o assédio sexual, verificar se houve responsabilidade in eligendo e in vigilando da empresa; (ix) sobre o controle externo (fora do horário e do local de trabalho), verificar se as práticas adotadas não atentam contra a intimidade e a vida privada dos trabalhadores ${ }^{291}$.

Por fim, a atuação do Ministério do Trabalho, por intermédio dos seus Auditores Fiscais, buscará a concretização da privacidade através da fiscalização, orientação e, caso necessário, a fixação de multas por não observação das regras de direito do trabalho relacionadas com a proteção da privacidade, especialmente as Normas Regulamentadoras que impõem obrigações ao empregador para a manutenção de um ambiente de trabalho sadio.

\subsection{Ações reativas}

\subsubsection{Afronta aos direitos da personalidade - consequências}

O artigo 186 do Código Civil determina que "aquele que, por ação ou omissão voluntária, negligência ou imprudência, violar direito e causar dano a outrem, ainda que exclusivamente moral, comete ato ilícito". O artigo 187 do mesmo diploma legal reconhece, também, a ilicitude do ato praticado pelo titular do direito que excede manifestamente os limites impostos pelo seu fim econômico ou social, pela boa-fé ou pelos bons costumes.

O empregador, ao exercer o seu poder diretivo, seja por ação, omissão ou até mesmo abuso de direito, pode cometer atos ilícitos, acarretando um dano ao empregado.

${ }^{291}$ SIMÓN, Sandra Lia. op. cit., p. 201-202. 
Na definição de Paulo Eduardo Vieira de Oliveira "dano é a lesão (efeito) de um ato humano ilícito, comissivo ou omissivo, decorrente de dolo ou culpa, que fere interesse alheio juridicamente protegido." 292

A afronta a um direito da personalidade resulta em um dano de natureza material e/ou moral, sendo que a definição da natureza do dano está relacionada com o âmbito da esfera do bem jurídico lesado.

O dano material ou patrimonial pode ser conceituado como aquele que "afeta o conjunto de bens pertencentes a uma pessoa, passíveis de estimação pecuniária". ${ }^{293}$ Apesar de o direito à privacidade se relacionar com um valor subjetivo do titular, a lesão deste direito pode atingir o patrimônio do empregado. A perda de uma oportunidade de emprego pela divulgação de dados privados do trabalhador é um bom exemplo de dano patrimonial decorrente da afronta à privacidade do empregado.

O dano moral ${ }^{294}$, em sua concepção moderna, não está ligado somente a dor ou a aspectos morais do indivíduo e ocorre quando há uma lesão a um direito da personalidade lato sensu, mais especificamente à sua integridade física, psíquica, intelectual, afetiva, moral e social. ${ }^{295}$

O dano moral pode ser direto, quando se origina diretamente do fato lesivo; ou indireto, quando o dano tem origem em um inadimplemento patrimonial (em razão do inadimplemento das verbas rescisórias o credor tem seu nome inscrito no órgão de proteção ao crédito); pode ser, também, reflexo ou em ricochete, quando atinge, por reflexo, pessoa diversa da que sofre diretamente o dano moral. ${ }^{296}$

Desta forma, não sendo possível agir preventivamente e uma vez configurado o dano material e/ou moral, a concretização da privacidade no ambiente de trabalho também se dá mediante o estabelecimento de reações contra atos patronais que acarretam a violação deste direito, trazendo como consequência sanções materiais e econômicas ao empregador que violar indevidamente a privacidade do empregado.

\footnotetext{
${ }^{292}$ OLIVEIRA, Paulo Eduardo Vieira. O dano pessoal no direito do trabalho, cit., p. 28.

${ }^{293}$ Id. Ibid., p. 32.

${ }^{294}$ A moderna doutrina critica a utilização da expressão "dano moral" preferindo se referir a "dano pessoal" como o ato que viola qualquer direito da personalidade (integridade psicofísica, intelectual, afetiva, moral e social). No entanto, considerando que a expressão "dano moral" já encontra-se arraigada no dia a dia jurídico, utilizaremos esse termo com a mesma compreensão que o dano pessoal.

${ }^{295} \mathrm{~A}$ concepção de dano moral ora apresentada foi extraída do conceito de dano pessoal exposto por Paulo Eduardo Vieira de Oliveira in $O$ dano pessoal no direito do trabalho, cit., p. 35 e 39.

${ }^{296}$ SCHIAVI, Mauro. Ações de reparação por danos morais decorrentes da relação de trabalho. 2. ed. São Paulo: LTr, 2008. p. 61.
} 
No que diz respeito à indenização pelo dano material sofrido, a definição da sua quantificação não suscita maiores discussões, pois a indenização é fixada objetivamente, considerando aquilo que o indivíduo perdeu diretamente, representado pela diminuição do seu patrimônio (dano emergente) e o que deixou de ganhar, ou seja, o lucro que deixou de auferir (lucro cessante) em razão do dano sofrido.

Todavia, se no dano material a fixação da indenização pode ser estabelecida de forma objetiva, tal situação não ocorre com o dano moral, cujo ressarcimento é uma questão polêmica, tendo em vista o caráter subjetivo do próprio direito cujo dano a indenização visa ressarcir.

Conforme já esclarecido, a doutrina e a jurisprudência moderna concebem dupla natureza à reparação do dano moral, qual seja: compensatória para a vítima e punitiva para o agente.

A ideia da imposição da reparação pecuniária como instrumento punitivo ou de desestímulo à prática do dano tem origem no direito americano, através da chamada punitive damages, onde o objetivo não é apenas a punição ao ofensor, mas também o exemplo que esta punição irá gerar na sociedade, com o intuito de desestimular a prática do ato ilícito. $\mathrm{O}$ conceito americano sofre críticas sob o argumento de dar margem a uma indústria de indenizações, estabelecendo patamares indenizatórios não condizentes com a realidade socioeconômica do Brasil e acarretando o enriquecimento indevido da parte lesada.

A legislação brasileira não estabeleceu critérios expressos para a fixação do valor da indenização por dano moral, sendo que o artigo 944 do Código Civil limita-se a prever, de forma genérica, que "a indenização mede-se pela extensão do dano", facultando, no seu parágrafo único, a redução da indenização na hipótese de excessiva desproporção entre a gravidade da culpa e o dano. O legislador brasileiro optou, portanto, pela adoção do sistema aberto para o estabelecimento da indenização do dano moral, na qual a fixação do ressarcimento pecuniário fica a critério do julgador, que deverá analisar os aspectos envolvidos caso a caso. ${ }^{297}$

Se, por um lado, a falta de fixação de critérios pré-determinados para a valoração da indenização "personaliza" o caso, forçando o intérprete a estabelecer, como base no seu livre convencimento, parâmetros fundamentados em razão da realidade colocada nos autos,

\footnotetext{
${ }^{297}$ O sistema aberto se contrapõe ao sistema fechado, também conhecido como tarifado, no qual o legislador estabelece critérios objetivos para a fixação do valor da indenização por dano moral.
} 
por outro lado, a falta de um balizamento maior dá margem à produção de decisões totalmente discrepantes para danos, aparentemente semelhantes.

Antonio Jeová Santos, utilizando as conclusões de Jorge Mosset Iturraspe, devidamente adaptadas ao sistema jurídico brasileiro, sugere os seguintes parâmetros para nortear juízes no estabelecimento do quantum do dano moral: a) a indenização é meramente convencional, sendo certo que não adotará critérios matemáticos certos e indiscutíveis, em razão de o dano moral ser incomensurável; b) a indenização não pode ser tão baixa a ponto de parecer uma indenização simbólica, devendo o valor estipulado se aproximar da tendência de castigar e suavizar, de algum modo, a dor e o sofrimento; c) a indenização não pode ser tão elevada a ponto de parecer extravagante, levando a um enriquecimento injusto da vítima ou a uma situação que nunca gozou; d) o valor a ser arbitrado deve estar dentro do contexto econômico do país; e) a indenização deve levar em conta a peculiaridade do caso discutido e a prova produzida nos autos; f) o juiz deve ter capacidade moderadora, de forma a estabelecer como indenização uma cifra razoável, condigna e que tenha relevância para ambas as partes; g) aplicação do critério da equidade e observação das circunstâncias particulares; h) estabelecimento de um ponto comum entre os juízes sobre a quantia na indenização dos danos morais, evitando-se diferenças exageradas, sem que isso represente tarifação ou vulneração à independência do juiz; i) a segurança jurídica deve ser perseguida, por isso a necessidade do consenso; e j) as decisões devem guardar entre si, de alguma forma, coerência. ${ }^{298}$

O estabelecimento de parâmetros mínimos a serem considerados pelo judiciário, ainda que respeitado o sistema aberto de fixação do valor da indenização vigente na legislação brasileira, bem como a necessidade de manter a independência do juiz na apreciação e mensuração individualizada no caso concreto, evitaria discrepâncias jurídicas e, em alguns casos, situações de injustiça.

O estabelecimento de indenizações justas e ponderadas - que visam não apenas reparar o prejuízo sofrido pelo empregado, como, também, buscam repreender o empregador pela prática adotada - também é um instrumento efetivo de concretização da privacidade do trabalhador. Isso porque, somente através da fixação de indenizações que atendam, efetivamente, à dupla natureza da indenização por dano moral é que será possível desenvolver a concretização da privacidade no ambiente de trabalho, visto que será muito difícil ao empregador reiterar a prática ofensiva a um direito da personalidade se for

\footnotetext{
${ }^{298}$ SANTOS, Antonio Jeová. Dano moral indenizável. São Paulo: Lejus, 1997. p. 70-77.
} 
condenado a pagar quantia expressiva de indenização em razão da afronta a este direito fundamental.

\subsubsection{Ações reativas individuais}

O titular do direito de reação contra a ofensa da privacidade é, em primeira instância, o próprio lesado, sendo que na relação de emprego o mais usual é o empregado ser o titular desse direito, não obstante se admita a afronta aos direitos da personalidade do empregador. $^{299}$ Além das partes diretamente envolvidas na relação de emprego, os descendentes, ascendentes, cônjuges, herdeiros e colaterais da parte lesada podem buscar a reparação do prejuízo causado.

O empregado dispõe de algumas medidas de reação contra atos patronais atentatórios à sua privacidade. O primeiro deles está previsto no artigo 483 da Consolidação das Leis do Trabalho e consiste na possibilidade de o empregado denunciar indiretamente o contrato de trabalho por falta grave praticada pelo empregador, recebendo os direitos rescisórios como se tivesse sido dispensado sem justa causa.

O Código do Trabalho português prevê que o empregador que descumprir uma de suas obrigações contratuais é passível de sanção com a responsabilidade prevista no artigo 363 do Código do Trabalho ou com a resolução do contrato na forma do artigo 441.2.b. Maria Regina Redinha sustenta que a afronta à reserva da vida privada, por configurar uma violação culposa aos deveres do empregador - notadamente o tratamento urbano e probo que é devido ao trabalhador - poderá ser invocada para a resolução do contrato e a aplicação de sanção ao empregador. ${ }^{300}$

O segundo instrumento consiste no habeas data, previsto no artigo $5^{\circ}$, LXXII, "a", da Constituição Federal, que é destinado a assegurar o conhecimento de informações relativas à pessoa do impetrante, constante de registro ou banco de dados de entidades governamentais ou de caráter público ou para a retificação de dados quando o titular não

\footnotetext{
${ }^{299} \mathrm{O}$ Código do Trabalho de Portugal, em razão do caráter bilateral do contrato de trabalho, prevê expressamente a concretização da privacidade para ambas as partes da relação de emprego. No direito do trabalho brasileiro, apesar da ausência de previsão legal expressa, é possível conceber o empregador como titular de direitos da personalidade que devem ser respeitados pelo empregado. No entanto, para a finalidade do presente trabalho, não nos interessa a verificação dos direitos da personalidade e o respectivo direito de reação do empregador.

${ }^{300}$ REDINHA, Maria Regina. Direitos de personalidade, cit., p. 2 .
} 
preferir fazê-lo por processo sigiloso, judicial ou administrativo. A Lei no 9.507/97, artigo $7^{\circ}$, inciso III também assegura a impetração do habeas data para a anotação nos assentamentos do interessado, de contestação ou explicação sobre dado verdadeiro, mas justificável, e que esteja sob pendência judicial ou amigável.

Sandra Lia Simón entende ser incontestável a relação do habeas data com a salvaguarda do direito à autodeterminação informativa, que é uma das manifestações do direito à privacidade. ${ }^{301}$

O terceiro instrumento é apontado por Raimundo Simão de Melo e consiste na propositura de ação popular, cujo direito de ação é garantido a qualquer cidadão pelo inciso LXXIII do artigo $5^{\circ}$ da Constituição e visa anular, dentre outros atos, a ação lesiva ao meio ambiente. No entanto, conforme destaca o mesmo autor, esse instrumento não tem sido utilizado em razão das dificuldades de ordem técnica, política e financeira, que acabam desencorajando a sua utilização. ${ }^{302}$

O quarto instrumento compreende o ajuizamento de ação reparatória com o objetivo de reconstituir o status quo do ofendido. Trata-se do instrumento mais utilizado pelo empregado em razão da dinâmica da relação de emprego.

Inobstante o empregado possa, a qualquer momento, adotar medidas para evitar ou fazer cessar a ameaça ao seu direito da personalidade, na quase totalidade dos casos, ele somente busca a tutela jurisdicional contra atos do empregador que afrontam a sua privacidade após a rescisão do contrato de trabalho, quando a lesão já foi consumada, sendo que a tutela somente serve para reparar o direito lesado. ${ }^{303}$

Duas são as modalidades de ação reparatória à disposição do ofendido, a saber: a natural (in natura) e a indenizatória ou pecuniária. Um mesmo ato de afronta à privacidade pode dar ensejo à cumulação das duas obrigações reparatórias ${ }^{304}$, sendo possível, também, a conversão da reparação natural em indenização.

A reparação natural consiste geralmente em uma obrigação de fazer, que visa reconstituir ao ofendido o estado natural das coisas à época da ofensa, mesmo que tal situação seja difícil de ser alcançada completamente quando estamos falando em dano moral. Na reparação da afronta aos direitos da personalidade na relação de emprego podem

\footnotetext{
${ }^{301}$ SIMÓN, Sandra Lia. op. cit., p. 196.

${ }^{302}$ MELO, Raimundo Simão de. op. cit., p. 88-89.

${ }^{303}$ Id. Ibid., p. 188.

${ }^{304}$ A maioria da doutrina e da jurisprudência trabalhista entendem ser possível a dupla indenização pelo mesmo ato.
} 
ser citados, como exemplo de reparação natural: eliminação do objeto causador do dano; suspensão da publicação ou da circulação de publicação ofensiva; destruição do documento ofensivo; retratação pública; reintegração ao emprego, dentre outros. A Lei 9.029/95 prevê expressamente a hipótese de reintegração ao emprego do trabalhador quando a sua dispensa for considerada discriminatória. Esta mesma norma legal também prevê a possibilidade de indenização tarifada por esta despedida ${ }^{305}$, cabendo ao empregado escolher o tipo de reparação que melhor lhe atender.

A reparação pecuniária, ou indenizatória, é assegurada a todos os cidadãos pelo inciso X do artigo $5^{\circ}$ da Constituição Federal. Atualmente, concebe-se como dúplice a natureza jurídica da reparação indenizatória, pois além de buscar compensar a vítima pelo dano sofrido, visa estabelecer uma punição e reeducação ao agente para desestimulá-lo a reiterar tal prática.

Nas hipóteses em que o empregador não tem possibilidade, em razão da sua condição financeira, de pagar indenização pecuniária devida ao ofendido, Raimundo Simão de Melo destaca para a possibilidade de estabelecimento de condenação a prestação de serviços alternativos de interesse da sociedade, conforme faculta o artigo $5^{\circ}$, XLVI, letra “d”, da Constituição Federal e do artigo 46 do Código Penal. Como bem destaca o autor, apesar de essa cominação não atender à satisfação da vítima pela indenização pecuniária, ao menos atende o segundo objetivo da sanção, que é a punição e reeducação do agente, além do caráter pedagógico que tal medida surte para outros prováveis ofensores. ${ }^{306}$

Por fim, cumpre apontar a punição criminal como mais um instrumento coercitivo punitivo importante para fazer valer a manutenção da privacidade. A tutela jurisdicional trabalhista não exclui eventual punição criminal, cujos detalhes não cabem ser analisados no presente trabalho. O importante é destacar que as tutelas jurisdicionais não se excluem, de forma que o exercício do direito de ação na esfera trabalhista não excluiu a tutela penal, pois os instrumentos coercitivos envolvidos nas duas áreas do direito se somam para garantir a efetividade do direito à privacidade.

\footnotetext{
${ }^{305} \mathrm{O}$ artigo $4^{\circ}$ da Lei 9.029/95 determina que a dispensa por ato discriminatório, nos moldes da lei, faculta ao empregado optar entre as seguintes reparações: readmissão com ressarcimento integral dos salários e demais vantagens devidas no período de afastamento; e percepção, em dobro, da remuneração do período de afastamento, com juros e correção monetária.

${ }^{306}$ MELO, Raimundo Simão de. op. cit., p. 475.
} 


\subsubsection{Ações reativas coletivas}

Conforme já destacado, no âmbito da relação de emprego, mesmo após o término da relação contratual, o empregado encontra dificuldades em fazer valer os instrumentos reativos individuais facultados pela legislação para a concretização da sua privacidade. A crise da economia, o desemprego estrutural, a dificuldade de acesso ao judiciário e a demora no andamento dos processos acabam desestimulando a adoção de medidas reativas por parte dos empregados de forma a buscar uma reparação pelo dano sofrido em razão de uma afronta ao seu direito de personalidade.

Por tal motivo, a tutela jurisdicional coletiva, que no âmbito da relação de emprego se materializa através da atuação do Ministério Público do Trabalho e das entidades sindicais profissionais e patronais, é muito importante para a concretização da privacidade no ambiente de trabalho.

O Ministério Público do Trabalho, no âmbito administrativo, poderá valer-se do Inquérito Civil Público, procedimento inquisitorial destinado a investigar sobre a ilegalidade do ato denunciado. Caso confirmada a irregularidade denunciada, o Promotor do Trabalho poderá propor a assinatura de um Termo de Ajustamento de Conduta pelo qual o inquirido se compromete a adequar-se à lei.

Judicialmente, o Ministério Público do Trabalho poderá ajuizar Ação Civil Pública, que se presta a proteger o patrimônio público e social, o meio ambiente e outros interesses difusos, coletivos ou individuais homogêneos. A Ação Civil Pública buscará a efetivação do direito, através da determinação de fazer ou não fazer e, dependendo do caso, em um aspecto mais punitivo, através da fixação de indenização por dano moral coletivo.

O Ministério Público do Trabalho também atuará como custus legis nas Ações Civis Públicas distribuídas pelos demais legitimados quando estas tratarem da preservação da privacidade como expressão de um meio ambiente do trabalho sadio. Conforme destaca Raimundo Simão de Melo, em razão do disposto no parágrafo $1^{\circ}$ do artigo $5^{\circ}$ da Lei n. 7.347/85, se o Ministério Público do Trabalho não for parte na ação, atuará, obrigatoriamente, como fiscal da lei, sob pena de nulidade do processo. ${ }^{307}$

Ao sindicato representante da categoria de empregados é facultado acionar o empregador judicialmente com ações plúrimas ou de cumprimento. A entidade sindical

\footnotetext{
${ }^{307}$ MELO, Raimundo Simão de. op. cit., p. 96.
} 
também tem legitimidade para propor Ação Civil Pública, com base no artigo $5^{\circ}$ da Lei 7.34/85, tendo importante papel na tutela da privacidade do trabalhador, considerando que o "homem-trabalhador" é a principal razão da constituição e existência da entidade sindical, cabendo a esta zelar pelo direito à liberdade, pelo direito à vida e pela dignidade da pessoa humana do trabalhador. ${ }^{308}$

Podemos também incluir - utilizando o raciocínio de Raimundo Simão de Melo as associações civis sem fins sindicais como legitimadas para adotar medidas judiciais visando à preservação dos direitos da personalidade dos trabalhadores, já que a garantia destes direitos é necessária para o estabelecimento de um meio ambiente de trabalho sadio. Esse entendimento decorre da interpretação a contrario sensu da previsão contida no inciso IV do artigo 82 do Código de Defesa do Consumidor, sendo possível que as associações civis sem fins sindicais, desde que autorizadas por meio de assembleia, atuem na defesa do meio ambiente do trabalho. ${ }^{309}$

\subsection{Responsabilidade pelo dano}

O artigo 927 do Código Civil determina que "aquele que por ato ilícito, causar dano a outrem, fica obrigado a repará-lo", especificando, ainda, que "haverá obrigação de reparar o dano, independente de culpa, nos casos especificados em lei, ou quando a atividade normalmente desenvolvida pelo autor do dano implicar, por sua natureza, risco para os direitos de outrem".

A responsabilidade civil é concebida por José Affonso Dallegrave Neto como sendo "a sistematização de regras e princípios que objetivam a reparação do dano patrimonial ou a compensação do dano extrapatrimonial causados diretamente por agente ou por fato de coisas ou pessoas que dele dependam - que agiu de forma ilícita ou assumiu o risco da atividade causadora da lesão".310

A teoria da responsabilidade se fundamenta na obrigação do agente em reparar o dano cometido, tendo como pressupostos: i) prática de ação ou omissão; culpa ou dolo (quando a sua responsabilidade for objetiva); ii) nexo de causalidade; e iii) dano

\footnotetext{
${ }^{308}$ SIMÓN, Sandra Lia. op. cit., p. 188.

${ }^{309}$ MELO, Raimundo Simão de. op. cit., p. 86-87.

${ }^{310}$ DALLEGRAVE NETO, José Affonso. Responsabilidade civil no direito do trabalho. São Paulo: LTr, 2005. p. 114.
} 
efetivamente experimentado pela vítima. Há, ainda, a possibilidade de a responsabilidade existir independente de dolo ou culpa, como consequência de exposição ao risco.

Conforme destaca Paulo Eduardo Vieira de Oliveira, "a responsabilidade trabalhista decorre do contexto da relação jurídica de emprego em que se situa. A relação empregatícia, fundamentalmente assimétrica com características próprias, fez com que, com o tempo, o direito lhe desse um tratamento diferenciado." 311

A responsabilidade do empregador pode ser contratual, decorrendo da execução do próprio contrato de trabalho; ou extracontratual, decorrendo de violação de dever geral previsto em lei ou na ordem jurídica. Vale lembrar que o empregador tem responsabilidade por mau zelo do ambiente de trabalho, pois é dele a obrigação de manter um ambiente de trabalho sadio, sendo que a preservação dos direitos da personalidade integra o rol de aspectos necessários para a manutenção de um ambiente de trabalho sadio.

A responsabilidade pode ser subjetiva ou objetiva, sendo que a primeira depende da existência de dolo ou culpa do agente, e a segunda tem a sua base na teoria do risco, na qual toda a pessoa que exerce uma atividade gera um risco de dano para terceiros, devendo ser obrigada a reparar este dano, ainda que não se verifique dolo ou culpa no ato. ${ }^{312}$

Ainda, a responsabilidade pode decorrer do uso irregular ou abuso de direito, como por exemplo, a extrapolação do poder diretivo do empregador.

Nas relações de emprego, conforme destaca Paulo Eduardo Vieira de Oliveira, não há como negar que a responsabilidade objetiva encontra grande incidência, pois a assunção do risco por parte do empregador, mesmo independente de culpa ou dolo, implica em responsabilidade pela reparação do dano de que o empregado seja vítima. ${ }^{313}$

Temos, portanto, que quando nos depararmos com qualquer lesão à privacidade do empregado a responsabilidade pela reparação dos prejuízos causados é do empregador e não prescinde da comprovação de dolo ou culpa, visto que o empresário, por assumir os riscos do negócio, obrigatoriamente é responsável pelos danos que causar aos seus empregados.

\footnotetext{
${ }^{311}$ OLIVEIRA, Paulo Eduardo Vieira. O dano pessoal no direito do trabalho, cit., p. 117.

${ }^{312}$ SILVA, Otávio Pinto e. Responsabilidade civil do empregador por acidente de trabalho. Synthesis, São Paulo, v. 47, n. 8, p. 25-28, 2008.

${ }^{313}$ OLIVEIRA, Paulo Eduardo Vieira. $O$ dano pessoal no direito do trabalho, cit., p. 125.
} 


\section{CONCLUSÃO}

Os direitos da personalidade, como direitos atinentes à natureza humana que visam resguardar a liberdade e a dignidade de forma a garantir o desenvolvimento do indivíduo em todos os seus aspectos (físico, moral, social, intelectual, etc.), acompanham o empregado independente da situação na qual este se encontra. $O$ patamar ao qual foi elevada a dignidade da pessoa no nosso ordenamento jurídico e os direitos fundamentais consagrados constitucionalmente não deixam dúvidas sobre a existência de uma cláusula geral de tutela e promoção da pessoa, que garante o respeito aos direitos da personalidade para situações não previstas em lei. Assim, a ausência de disposição legal trabalhista expressa conferindo ao trabalhador o direito ao desenvolvimento a sua personalidade não impede o reconhecimento deste direito no ambiente de trabalho.

Em que pese o contrato de trabalho celebrado entre empregado e empregador conferir a este último a prerrogativa de dirigir a prestação pessoal do primeiro, a relação de subordinação que se estabelece entre as partes está limitada à atividade desenvolvida e não recai sobre a pessoa do trabalhador. O empregado não está submisso pessoalmente ao empregador, o que reforça a idéia de garantia da individualidade e personalidade do trabalhador em todas as fases da relação de emprego.

De igual forma, a simples proteção do patrimônio do empregador, em que pese constar como direito fundamental no rol do artigo $5^{\circ}$ da Constituição Federal, por ser uma garantia meramente patrimonial, não é legítima para negar o direito à privacidade do trabalhador.

Após essas considerações, apesar de reconhecermos a existência de uma tutela geral de privacidade do trabalhador, entendemos que a dinâmica do contrato de trabalho não possibilita o gozo ilimitado e irrestrito deste direito da personalidade no ambiente empresarial. A um, porque o simples fato de o trabalhador estar no local de trabalho não lhe garante o mesmo nível de liberdade que ele possui em sua residência ou em suas relações pessoais. A dois, porque ao colocar a sua força de trabalho à disposição do empregador, o trabalhador perde parte de sua autonomia, visto não poder se negar a cumprir determinações empresariais emanadas dentro dos limites legais. A três, em razão de existirem situações em os direitos da personalidade do trabalhador encontrarão naturais limitações decorrentes de eventual confronto com os direitos fundamentais de outras 
pessoas (do próprio empregador, dos colegas e de terceiros) de igual ou maior ordem, como o direito à vida, à saúde ou à segurança, sobre os quais não é possível admitir a prevalência absoluta da privacidade. E a quatro, porque existem situações que em razão da natureza da atividade desenvolvida pelo trabalhador a limitação da privacidade é imposta por ordem legal.

Sustentar a garantia irrestrita e ilimitada da privacidade do trabalhador sem considerar os aspectos acima apontados representa a admissão da supremacia do empregado contra todos os demais direitos envolvidos na complexa relação de trabalho, com o que não concordamos.

A solução para garantir a preservação da privacidade do trabalhador considerando todos os aspectos destacados acima não é simples.

Como toda relação jurídica complexa, entendemos não ser possível estabelecer uma regra absoluta para solucionar o problema que deriva da intensificação do controle e fiscalização dos empregados em razão da aplicação de novos aparatos tecnológicos por parte do empregador. Se por um lado não é possível afirmar que é vedada qualquer forma de controle ou fiscalização que impeça o pleno exercício dos direitos da personalidade do empregado; por outro lado, também não há como sustentar que o poder diretivo do empregador autoriza qualquer ato patronal que vise organizar, fiscalizar e punir o trabalhador.

As relações de trabalho modernas não se resolvem com qualquer das duas afirmações acima apontadas, sendo que para buscarmos a concretização da privacidade do trabalhador no ambiente de trabalho, paradoxalmente, faz-se necessária a aceitação da limitação deste direito em algumas hipóteses para integrá-lo com dos demais direitos que também merecem proteção.

Assim, apesar de concebermos o empregado como detentor de direitos da personalidade na relação de emprego, ousamos estabelecer as seguintes condições sob as quais seria possível admitir a limitação da privacidade do trabalhador:

a) Quando estiverem em jogo outras garantias constitucionais de igual ou maior relevância, especialmente relacionadas a terceiros ou à coletividade. Por esse raciocínio, a vida, a saúde e a segurança colocam-se em plano de maior destaque que a privacidade, o que justifica a sua limitação. 
b) Quando a limitação da privacidade for condição para a execução do próprio contrato. Essa exceção está representada pelas situações em que uma maior restrição aos direitos fundamentais do trabalhador impõe-se como condição para a execução do próprio contrato, seja porque imposta por lei, seja porque decorre da ponderação de bens de interesse de igual ou maior relevância, sempre tendo em vista a premissa de que a simples preservação do direito de propriedade não é legítima para justificar a restrição a qualquer direito de personalidade. A limitação da privacidade é aceita apenas nas situações em que for imprescindível para o desenvolvimento do contrato.

c) Quando houver forte e concreto indício de má-fé por parte do empregado. Essa exceção deve ser aplicada de forma muito criteriosa, pois somente será admitida quando os indícios desta quebra forem fortes e concretos e quando não houver outro meio para se averiguar a efetiva quebra de confiança.

d) Quando houver indício de má utilização dos instrumentos de trabalho de forma a causar prejuízos a terceiros. Essa exceção decorre da obrigação legal que o empregador possui de preservar terceiros alheios ao contrato de trabalho contra atos prejudiciais praticados por seus empregados. Em razão dessa obrigação, o empregador tem o poder/dever de estabelecer mecanismos de proteção contra atos de seus empregados capazes de causar prejuízos a terceiros, estando autorizado a limitar o exercício pleno da privacidade do trabalhador.

Para evitar que as exceções ora apresentadas sejam utilizadas de forma abusiva pelo empregador, entendemos que a limitação da privacidade do empregado se submete ao atendimento de alguns requisitos que deverão ser observados obrigatoriamente, a saber:

a) Respeito máximo e limitação mínima visando a manutenção do núcleo essencial da privacidade, como expressão da dignidade da pessoa humana. A limitação deve ocorrer de forma a respeitar o mínimo do direito fundamental, ou seja, o seu núcleo essencial. Mesmo com a limitação, deve haver a proteção mínima dos direitos fundamentais do trabalhador, notadamente a sua dignidade.

b) A limitação deve ser imprescindível, adequada e proporcional, não sendo possível a obtenção do mesmo fim por outros meios.

c) O empregado deve ter conhecimento prévio do instrumento utilizado para limitar a privacidade, com a sua respectiva justificativa por parte do empregador, devendo 
autorizar expressamente a limitação, pois tais imposições decorrem do dever de boa-fé, transparência e informação que permeia o contrato de trabalho.

d) $\mathrm{O}$ instrumento de limitação deve ser negociado com entidades representantes dos trabalhadores (comissão de fábrica, sindicato) e, na ausência destes, deverá contar com a anuência do Ministério Público do Trabalho.

De igual forma, entendemos que a limitação não será poderá ser aceita em qualquer hipótese ou por qualquer interesse do empregador, tampouco estará fundamentada no exercício do direito de propriedade patronal. As situações nas quais a limitação será admissível estão adstritas às hipóteses em que a restrição é imprescindível, seja para a execução do próprio contrato de trabalho (em razão das suas peculiaridades técnicas), seja para a garantia de outros direitos fundamentais de igual ou maior relevância que a garantia individual de privacidade.

As exceções acima apresentadas não deixam de ser uma forma de concretização da privacidade, pois concebem esse direito dentro da complexa relação que se estabelece através do contrato de trabalho. A privacidade do empregado é concretizada sem afastar os outros interesses em jogo, quais sejam, o exercício do poder diretivo do empregador e impossibilidade de afronta ou negação de outros direitos fundamentais existentes (caso da vida, liberdade, saúde, segurança, etc.).

Diante das premissas apresentadas acima, ao nos depararmos com as inúmeras situações nas quais há potencial afronta à privacidade do trabalhador, concluímos que sempre deverá ser buscada a tutela desse direito da personalidade sem deixarmos de considerar os outros direitos envolvidos.

Assim, temos que a exigência da realização de testes ou exames de gravidez para a contratação ou a manutenção do contrato representa uma violação da privacidade da empregada, além de ter caráter flagrantemente discriminatório. A dignidade da pessoa humana, o princípio geral de igualdade e não discriminação e a garantia fundamental de proteção da esfera íntima da trabalhadora, além da expressa vedação legal, não admitem qualquer sopesamento ou ponderação de interesses do empregador.

A obrigatoriedade de submissão do empregado a exames médicos legais não lhe retira o direito ao resguardo destes seus resultados, que não poderão ser comunicados para terceiros, salvo hipóteses excepcionais determinadas por lei e que envolvam questões relacionadas à vigilância sanitária. 
Quanto aos exames não determinados por lei, concluímos pela regra geral de proibição, salvo quando a natureza da atividade exercida pelo empregado exigir a realização do exame para garantir a preservação de um direito de igual ou maior relevância e abrangência, como a vida ou a saúde de terceiros, por exemplo.

Entendemos que os testes e exames genéticos não comportam qualquer exceção, visto que a determinação da carga genética do trabalhador não poderá ser invocada. Tal conclusão se deve ao fato de o mapeamento genético ser de foro extremamente íntimo, desconhecido pelo próprio empregado e, ainda, porque a investigação genética extrapola a pessoa do trabalhador, demonstrando apenas uma tendência ao desenvolvimento de doença que sequer poderá ser confirmada.

$\mathrm{Na}$ fase pré-contratual e durante a execução do contrato, entendemos que os questionários utilizados pelo empregador como meio de obtenção de informações de seus empregados somente poderão adentrar em questões relacionadas com o desempenho, não sendo possível a apresentação de perguntas sobre raça, religião, condição social, convicções políticas, vida familiar ou afetiva, etc., quando desnecessárias para o exercício da função. Questionários que extrapolam os limites do contrato, além de atentatórios à privacidade do trabalhador, são discriminatórios.

Quando o empregado se deparar com situações em que for questionado sobre aspectos da sua vida privada que não possuem relação direta com o contrato de trabalho, entendemos que ele poderá se omitir na resposta, por não ter obrigação em responder sobre fatos que dizem respeito a sua esfera pessoal e que não são imprescindíveis para a execução do contrato de trabalho.

Nas hipóteses em que o empregador estiver autorizado a coletar os dados do trabalhador, sustentamos que estes dados devem ser tratados de forma digna, sendo que as informações pessoais coletadas nas fases pré, inter e pós-contratual não poderão ser divulgadas pelo empregador para colegas de trabalho ou para terceiros. De igual forma, as informações deverão ser arquivadas de forma a garantir o seu sigilo e somente poderão ser mantidas nos arquivos do empregador enquanto perdurar a relação de emprego.

Quanto aos dados biométricos, entendemos que estes poderão ser recolhidos em situações especialíssimas, principalmente quando, por questões de segurança, se fizer imprescindível a identificação do trabalhador através dos seus dados personalíssimos e 
desde que a sua guarda seja mantida apenas durante o período em que perdurar a relação de emprego.

Partindo para os sistemas de vigilância e monitoramento, entendemos que essa modalidade de controle somente é possível quando necessária para o estrito exercício da atividade, como o controle técnico da produção, por exemplo, e quando necessária para garantir a segurança do ambiente no qual os trabalhadores estão inseridos. A vigilância ostensiva com a simples finalidade de controle da produção não é possível, pois não é um meio necessário, adequado e proporcional para este fim.

O mesmo raciocínio pode ser utilizado para a gravação de conversas telefônicas, sendo que a possibilidade de gravação e monitoramento do conteúdo das ligações é possível em casos muito excepcionais que visem garantir a segurança e a saúde dos envolvidos.

A contratação de espiões ou clientes "disfarçados" para averiguar a qualidade dos serviços prestados pelos empregados se assemelha à hipótese do monitoramento remoto com a exclusiva finalidade de aferição da produtividade do trabalhador, razão pela qual entendemos não ser possível tal prática.

Quanto ao monitoramento do e-mail e internet no ambiente de trabalho, defendemos não ser possível o acesso total ao conteúdo das mensagens eletrônicas (pessoais ou profissionais) enviadas pelos empregados no ambiente de trabalho. No entanto, aceitamos a possibilidade de imposição de algumas limitações ao trabalhador na utilização destas ferramentas eletrônicas. Sustentamos que o empregador está autorizado a limitar a utilização do correio eletrônico e o acesso à internet no ambiente de trabalho não em razão do exercício do seu poder diretivo ou de propriedade, mas sim por obrigação legal. Diante da responsabilidade do empregador perante terceiros, que impõe ao primeiro a obrigação de zelar para impedir a utilização indevida dos instrumentos de trabalho colocados à disposição do trabalhador, de forma a causar prejuízos a terceiros, entendemos que o empregador está autorizado a estabelecer critérios objetivos para a verificação da atuação do empregado frente à internet e ao correio eletrônico. Ou seja, a intimidade do empregado não é limitada em decorrência do direito de propriedade do empregador sobre o computador ou do exercício do seu poder diretivo, mas sim em razão do interesse público envolvido, para que o uso ilícito da internet e do correio eletrônico não vise à prática de atividades ilícitas ou para causar prejuízos a terceiros alheios à relação de emprego. 
No que diz respeito às revistas, entendemos que a íntima, por expressa vedação legal, é proibida; e a pessoal também não pode ser realizada com o exclusivo intuito de proteção patrimonial do empregador. Contudo, entendemos que a revista pessoal poderá excepcionalmente ser autorizada quando constituir requisito essencial para a execução do próprio contrato de trabalho ou quando for necessária para garantir a preservação da segurança ou da saúde da coletividade, desde que adotadas todas as precauções necessárias no sentido de garantir ao máximo o respeito à privacidade do trabalhador.

Para encerrar o rol dos exemplos apresentados no presente estudo, não admitimos a existência de qualquer justificativa ou interesse maior capaz de autorizar a aplicação do detector de mentira (polígrafo), sendo que a utilização deste método representa um atentado à privacidade e à dignidade do empregado.

Após a reflexão sobre a construção das premissas que defendemos que a privacidade do trabalhador deverá ser concretizada e da sua aplicação aos casos específicos, chegamos à conclusão que a solução apresentada na presente dissertação muito se assemelha à solução dada pelo legislador português na atual redação do Código do Trabalho. Da comparação entre os artigos do Código do Trabalho de Portugal que tratam dos direitos da personalidade com as considerações apresentadas na presente dissertação, constatamos que as soluções para a concretização da privacidade do trabalhador são semelhantes, pois em ambos os casos parte-se de uma regra de tutela geral de privacidade que admite exceções que são justificadas pela necessidade técnica de execução do contrato de trabalho ou na proteção de outros direitos fundamentais de igual ou maior valor. Em ambos os casos, a admissão de exceções à cláusula geral de privacidade não representa renúncia ao direito, em razão do estabelecimento de condições necessárias para a proteção do núcleo essencial da privacidade e a garantia da dignidade ao trabalhador.

O motivo para constarmos, ao final do estudo, a forte influência do Código do Trabalho de Portugal sobre as conclusões da presente dissertação reside em dois fatores. A primeira decorre na indireta e natural influência em razão da escassa normatização em termos de direito da personalidade nas demais legislações trabalhistas estudadas (Brasil, Itália, Espanha e França). O segundo e principal motivo consiste no fato de a legislação trabalhista portuguesa ser recente (a última redação do Código é de 2009) e contemporânea, preocupando-se com a disciplina de matérias que envolvem o moderno direito do trabalho e, especialmente, de conceber o empregado como cidadão na relação de emprego. 
Apesar de sustentarmos ao longo da dissertação não ser imprescindível a normatização expressa dos direitos da personalidade na legislação trabalhista para que estes direitos sejam concretizados na relação de emprego, entendemos que a inclusão de dispositivos específicos na Consolidação das Leis do Trabalho para tratar de forma mais detalhada alguns direitos da personalidade do empregado, em especial a privacidade, auxiliaria na consolidação da noção de que a subordinação inerente ao contrato de trabalho não impede a garantia da privacidade do trabalhador.

Assim, quando compreendermos a necessidade de disciplinar o tratamento da privacidade no ambiente de trabalho, entendemos que um bom exemplo a ser seguido é o Código de Trabalho de Portugal, por estabelecer uma garantia geral de preservação da privacidade do trabalhador sem deixar de cuidar e disciplinar as exceções que decorrem naturalmente da dinâmica do contrato de trabalho expostas na presente dissertação. Além disso, contém uma cláusula geral de tutela da "reserva da intimidade da vida privada" (artigo 16), que sempre poderá ser invocada para a proteção do empregado nas situações eventualmente não concretizadas pelo Código do Trabalho.

Por fim, para a efetiva concretização da privacidade do trabalhador, não podemos deixar de mencionar os instrumentos colocados à disposição no âmbito da relação de emprego para fazer valer o direito à privacidade do trabalhador. São medidas preventivas e reativas que visam evitar a afronta à privacidade do empregado, estabelecendo vedações ao empregador no exercício do seu poder diretivo. Nesse sentido, o papel do empregado, dos sindicatos, dos Auditores Fiscais do Trabalho e do Ministério Público do Trabalho é essencial, pois a estes (além do próprio empregador) também cumpre zelar por um ambiente de trabalho sadio, que compreende o respeito aos direitos da personalidade do trabalhador. 


\section{REFERÊNCIAS BIBLIOGRÁFICAS}

ALONSO OLEA, Manuel. Derecho del trabajo. Madrid: Universidad de Madrid, 1980.

BACARAT, Eduardo Milléo. A boa-fé no direito individual do trabalho. São Paulo: LTr, 2002.

BARROS, Alice Monteiro de. Curso de direito do trabalho. São Paulo: LTr, 2005.

Poder hierárquico do empregador. Poder diretivo. In: (Coord.) Curso de

direito do trabalho: estudos em memória de Célio Goyatá. 2 ed. rev. atual. e ampl. São Paulo: LTr, 1994.

. Proteção à intimidade do empregado. São Paulo: LTr, 1997.

BASTOS, Celso Ribeiro. Curso de direito constitucional. 19 ed. atual. São Paulo: Saraiva, 1998.

BAYlos, Antonio. Ciudadanía en el trabajo. Revista do Advogado, São Paulo, ano 30, dez. 2010. Relações de Trabalho: Justiça e Equilíbrio. Homenagem a José Granadeiro Guimarães João José Sady.

BELMONTE, Alexandre Agra. O monitoramento da correspondência eletrônica nas relações de trabalho. São Paulo: LTr, 2004.

BITTAR, Carlos Alberto. Os direitos da personalidade. 3.ed. Rio de Janeiro: Forense Universitária, 1999.

CANOTILHO, Joaquim José Gomes. Direito constitucional. Coimbra: Almedina, 1991. Direito constitucional e teoria da constituição. 5. ed. Coimbra: Almedina, 1991.

CARNAVAN, Fernando Leone. Tutela dos direitos da personalidade no direito do trabalho. 2002. Dissertação (Mestrado em Direito) - Faculdade de Direito, Universidade de São Paulo, São Paulo, 2002.

CATHARINO, José Martins. O poder disciplinar do empregador e o princípio da ampla defesa. Repertório IOB de Jurisprudência, Rio de Janeiro, n. 24, 2. quinz. dez. 1993.

CESARINO JÚNIOR, Antônio Ferreira. Direito social. 2. ed. São Paulo: LTr, 1993. v. 1.

CHIMENTI, Ricardo Cunha et al. Curso de direito constitucional. 4. ed. São Paulo: Saraiva, 2007. 
COMUNIDADE EUROPÉIA. Diretiva 95/46/CE do Parlamento Europeu e do Conselho de 24 de outubro de 1995. Relativa à protecção das pessoas singulares no que diz respeito ao tratamento de dados pessoais e à livre circulação desses dados. Disponível em: $<$ http://www.umic.pt/images/stories/publicacoes200709/Directiva95_46_CE.pdf $>$. Acesso em: 02 dez. 2010.

CONSELHO DA EUROPA. Convenção para a Protecção dos Direitos do Homem e das Liberdades Fundamentais (Modificada nos termos das disposições do Protocolo $\mathrm{n}^{\circ} 11$ ). Gabinete de Documentação e Direito Comnparado. Disponível em: $<$ www.gddc.pt/direitos-humanos/textos-internacionais-dh/tidhregionais/conv-tratados-0411-950-ets-5.html>. Acesso em: 02 dez. 2010.

CORDEIRO, Antonio Menezes. Manual de direito do trabalho. Coimbra: Almedina, 1991. COSTA JÚNIOR, Paulo José. O direito de estar só: tutela penal da intimidade. São Paulo: Ed. Revista dos Tribunais, 1970.

CREMESP.

$<$ http://www.cremesp.org.br/library/modulos/legislacao/versao_impressao.php?id=8822>. Acesso em: 20 dez. 2010.

DALLEGRAVE NETO, José Affonso. Responsabilidade civil no direito do trabalho. São Paulo: LTr, 2005.

DECLARAÇÃO DOS DIREITOS DO HOMEM E DO CIDADÃO. DHnet - Direitos Humanos $\quad$ Internet. Disponível em: <http://www.dhnet.org.br/direitos/anthist/dec1789.htm>. Acesso em: 22 set. 2010.

DE CUPIS, Adriano. Os direitos da personalidade. Tradução de Adriano Vera Jardim e Antônio Miguel Caeiro. Lisboa: Livraria Morais, 1961.

DELGADO, Maurício Godinho. Curso de direito do trabalho. 3 ed. São Paulo: LTr, 2004. O poder empregatício. São Paulo: LTr, 1996.

DONEDA, Danilo. Da privacidade à proteção de dados pessoais. Rio de Janeiro: Renovar, 2006.

Privacidade, vida privada e intimidade no ordenamento jurídico brasileiro: da emergência de uma revisão conceitual e da tutela de dados pessoais. Ambito Jurídico. Disponível em: <http://www.ambitojuridico.com.br/site/index.php?n_link=revista_artigos_leitura\&artigo_id=2460>. Acesso em: 28 set. 2010. 
EUR-Lex: acesso ao direito da União Européia. Disponível em: <http://eurlex.europa.eu/pt/index.htm>. Acesso em 05 dez. 2010.

EUROPEAN PARLIAMENT. Carta dos Direitos Fundamentais da União Européia. Jornal Oficial das Comunidades Européias, C364/1, 18.12.2000. Disponível em: <http://www.europarl.europa.eu/charter/pdf/text_pt.pdf>. Acesso em: 18 nov. 2010.

FRANÇA, Rubens Limongi. Direitos da personalidade: coordenadas fundamentais. Revista Acadêmica Brasileira de Letras Jurídicas, Rio de Janeiro, v. 7, n. 4, 1993.

GARCIA, Gustavo Filipe Barbosa. Curso de direito do trabalho. 2. ed. rev. atual. e ampl. São Paulo: Método, 2008.

GOMES, Júlio Manuel Vieira. Direito do trabalho: relações Individuais de trabalho. Coimbra: Coimbra Ed., 2007. v. 1.

GOMES, Orlando; GOTTSCHALK, Elson. Curso de direito do trabalho. 10. ed. Rio de Janeiro: Forense, 1987.

GUERRA, Amadeu. A privacidade no local de trabalho: as novas tecnologias e o controlo dos trabalhadores através de sistemas automatizados: as alterações do Código do Trabalho. Coimbra: Almedina, 2004.

HAINZENREDER JÚNIOR, Eugênio. Direito à privacidade e poder direito do empregador. São Paulo: Atlas, 2009.

INSTITUTO AMP. Disponível em: <http://www.institutoamp.com.br/oit155.htm>. Acesso em: 16 dez. 2010.

INTERNATIONAL LABOUR ORGANIZATION. Conferência Internacional do Trabalho. Recomendação 200. Recomendação sobre a infecção VIH e SIDA e o mundo do trabalho, adoptada pela Conferência Internacional do Trabalho na sua nonagésima nona sessão, em Genebra, a 17 de junho de 2010. Disponível em: $<$ http://www.ilo.org/public/portugue/region/eurpro/lisbon/pdf/recomendacao_200.pdf> Acesso em: 05 dez. 2010.

JÚRIS Sintese IOB, mar./abr. 2009. CD-ROM.

LEITÃO, Luís Menezes, A protecção dos dados pessoais no Código do Trabalho: a Reforma do Código do Trabalho. Coimbra, 2004.

LEWICKI, Bruno. A privacidade da pessoa humana no ambiente de trabalho. Rio de Janeiro: Renovar, 2003. 
MAGANO, Octavio Bueno. Do poder diretivo da empresa. São Paulo: Saraiva, 1982. . Manual de direito do trabalho. 4 ed. São Paulo: LTr, 1993. v. 2.

MALLET, Estêvão. Direitos de personalidade e direito do trabalho. Revista do Advogado, São Paulo, v. 24, n. 76, p. 12-20, jun. 2004.

MARTINEZ, Pedro Romano. Direito do trabalho. 3. ed. Coimbra: Almedina, 2006.

MARTINS, João Nuno Zenha. O genoma humano e a contratação laboral: progresso ou fatalismo? Oeiras: Celta Ed., 2002.

MARTINS, Nei Frederico Cano; MAUAD, Marcelo José Ladeira. Lições de direito individual do trabalho. São Paulo: LTr, 2002.

MARTINS, Sérgio Pinto. Direito do trabalho. 19. ed. São Paulo: Atlas, 2004.

MEIRELES, Rose Melo Vencelau. Autonomia privada e dignidade humana. Rio de Janeiro: Renovar, 2009.

MELO, Raimundo Simão de. Direito ambiental do trabalho e a saúde do trabalhador. 4. ed. São Paulo: LTr, 2010.

MESQUITA, Luiz José de. Direito disciplinar do trabalho. 2. ed. São Paulo: LTr, 1991.

MIRANDA, Francisco Cavalcanti Pontes de. Tratado de direito privado: parte especial. Rio de Janeiro: Borsoi, 1955. v. 8.

MONTEIRO, Washington de Barros. Curso de direito civil. 39. ed. São Paulo: Saraiva, 2003. v. 1.

MORAES, Alexandre de. Constituição do Brasil interpretada e legislação constitucional. São Paulo: Atlas, 2002.

Direito constitucional. 16. ed. São Paulo: Atlas, 2004.

MORAES, Maria Celina Bodin de. Apresentação. In: RODOTÀ, Stefano. A vida na sociedade da vigilância. A privacidade hoje. Rio de Janeiro: Renovar, 2008.

MOREIRA, Teresa Alexandra Coelho. Da esfera privada do trabalhador e o controlo do empregador. Coimbra: Coimbra Ed., 2004.

NASCIMENTO, Amauri Mascaro. Curso de direito do trabalho. 12. ed. São Paulo: Saraiva, 1996.

Iniciação ao direito do trabalho. 14. ed. São Paulo: LTr, 1989. 
NASCIMENTO, Amauri Mascaro. Iniciação ao direito do trabalho. 21. ed. rev. e atual. São Paulo: LTr, 1994.

OLIVEIRA, Oris. A pessoalidade no contrato individual de trabalho. Revista Legislação do Trabalho e Previdência Social, São Paulo, v. 38, n. 2, p. 118-122, fev. 1974.

OLIVEIRA, Paulo Eduardo Vieira de. Aula proferida na disciplina "Direitos da Personalidade e Direito do Trabalho" na Pós Graduação da Faculdade de Direito da Universidade de São Paulo, São Paulo, 20 set. 2010.

O dano pessoal no direito do trabalho. São Paulo: LTr, 2002.

. O dano pessoal no direito do trabalho. 2 ed. São Paulo: LTr, 2010.

A privacidade da pessoa humana no ambiente de trabalho. Revista do Departamento de Direito do Trabalho e da Seguridade Social da Faculdade de Direito da USP, São Paulo, v. 1, n. 1, p. 163-183, jan./jun. 2006.

OLIVEIRA NETO, Alberto Emiliano de et al. Vida privada do empregado: revistas íntimas, boa aparência e estética. Aldacy Rachid Coutinho (orientador). Revista da Academia Brasileira de Direito Constitucional, Curitiba, v. 4, p. 145-174, 2003.

PAESANI, Liliane Minardi. Direito e internet: liberdade de informação, privacidade e responsabilidade civil. São Paulo: Atlas, 2000.

PAMPLONA FILHO, Rodolfo. O dano moral na relação de emprego. 3. ed. ampl. rev. e atual. de acordo com o novo Código Civil Brasileiro. São Paulo: LTr, 2002.

PENDAS, Benigno. Introdução. In: THE RIGHT to privacy para o espanhol sob o título El derecho a la intimidad. Madrid: Civitas, 1995.

PEREIRA, Caio Mario da Silva. Instituições de direito civil. 20. ed. Rio de Janeiro: Forense, 2004. v. 1.

PINTO, José Augusto Rodrigues. Curso de direito individual do trabalho: noções fundamentais de direito individual do trabalho, sujeitos e institutos do direito individual. 4. ed. São Paulo: LTr, 2000.

REDINHA, Maria Regina. Direitos de personalidade. Disponível em:

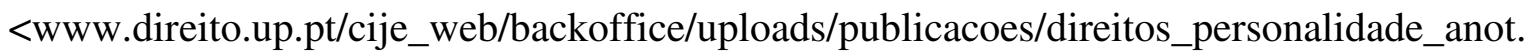
pdf>. Acesso em: 10 mar. 2009.

Os direitos de personalidade no Código do Trabalho: actualidade e oportunidade da sua inclusão. In: A Reforma do Código do Trabalho. Coimbra: Coimbra Ed., 2004. 
REZENDE, Roberto Vieira de Almeida. Delineamento constitucional do poder diretivo. 2004. Tese (Doutorado) - Faculdade de Direito, Universidade de São Paulo, São Paulo, 2004.

RIBEIRO, Lélia Guimarães Carvalho. Tutela da personalidade do trabalhador. Suplemento Trabalhista LTr, São Paulo, v. 31, n. 62, 1995.

RODOTÀ, Stefano. A vida na sociedade da vigilância: a privacidade hoje. Rio de Janeiro: Renovar, 2008.

RODRIGUES, Silvio. Direito civil: parte geral. 23. ed., atual. São Paulo: Saraiva, 1993. v. 1.

ROMITA, Arion Sayão. Direitos fundamentais nas relações de trabalho. São Paulo: LTr, 2005 .

. A subordinação no contrato de trabalho. Rio de Janeiro: Forense, 1979.

SAMPAIO, José Adércio Leite. Direito à intimidade e à vida privada. Belo Horizonte: Del Rey, 1998.

SANSEVERINO, Luisa Riva. Curso de direito do trabalho. Tradução de Élson Gottschalk. São Paulo: LTr, 1976.

SANTOS, Antonio Jeová. Dano moral indenizável. São Paulo: Lejus, 1997.

SARLET, Ingo Wolfgang. Dignidade da pessoa humana e direitos fundamentais na Constituição Federal de 1988. 8 ed. rev. ampl. atual. Porto Alegre: Livr. do Advogado, 2010.

SARMENTO, Daniel. Direitos fundamentais e relações privadas. Rio de Janeiro: Lumen Juris, 2004.

SCHIAVI, Mauro. Ações de reparação por danos morais decorrentes da relação de trabalho. 2. ed. São Paulo: LTr, 2008.

SILVA, José Afonso da. Curso de direito constitucional positivo. 9 ed. São Paulo: Malheiros Ed., 1994.

SILVA, Otávio Pinto e. Responsabilidade civil do empregador por acidente de trabalho. Synthesis, São Paulo, v. 47, n. 8, p. 25-28, 2008.

Subordinação, autonomia e parassubordinação nas relações de trabalho. São Paulo: LTr, 2004. 
SIMÓN, Sandra Lia. A proteção constitucional da intimidade e da vida privada do empregado. São Paulo: LTr, 2000.

SOUSA, Radindranath Valentino Aleixo Capelo de. $O$ direito geral de personalidade. Coimbra: Coimbra Ed., 1995.

SOUTO MAIOR, Jorge Luiz. Do direito à desconexão do trabalho. Revista do Departamento de Direito do Trabalho e da Seguridade Social, São Paulo, v. 1, n. 1, p. 91115, jan./jun. 2006.

STOCO, Rui. Tratado de responsabilidade civil. 6. ed. rev. atual. e ampl. São Paulo: Ed. Revista dos Tribunais, 2004.

SÜSSEKIND, Arnaldo et al. Instituições de direito do trabalho. 21. ed. atualizada por Arnaldo Süssekind e João de Lima Teixeira Filho. São Paulo: LTr, 2003, v. 1.

TEPEDINO, Gustavo. Temas de direito civil. Rio de Janeiro: Renovar, 1999.

THIBAULT ARANDA, Javier. Aula ministrada na Disciplina: Reforma Trabalhista - A Experiência Espanhola, na Pós Graduação da Faculdade de Direito da Universidade de São Paulo, em set. 2008.

Control multimedia de la actividade laboral. Valencia: Tirant le Blanch: 2006.

TORRINHA, Francisco. Dicionário latino português. 7. ed. Porto: Gráficos Reunidos, 1999.

UNITED STATES DEPARTAMENT OF LABOUR. Employee Polygrafh Protection Act of 1988. Disponível em: <http://www.dol.gov/esa/whd/regs/statutes/poly01.pdf>. Acesso em: 28 jun. 2009.

UNIVERSIDADE DE SÃO PAULO. Biblioteca Virtual de Direitos Humanos. Disponível em: <www.direitoshumanos.usp.br>.

VIANA, Márcio Túlio. Direito de resistência. São Paulo: LTr, 1996.

VIANNA, Túlio Lima. Violação à privacidade: quero monitorar os e-mails dos ministros do TST! Conjur. Disponível em: <http://www.conjur.estadao.com.br>. Acesso em: 21 maio 2005.

VIEIRA, Tatiana Malta. $O$ direito à privacidade na sociedade da informação: efetividade desse direito fundamental diante dos avanços da tecnologia da informação. Porto Alegre: Sergio Antonio Fabris Editor, 2007. 